د. ف فهر صالح الخنه

\title{
صور الحساب في القرآن والسنة
}

د. ـ فه صالح الخنه (")

المقدمة :

الحمد لله رب العـالمين وسـع كل شـيء علمًا الذي وضـع الموازين بالقسط وأحصى كل شيء عددًا والصلاة والسلام على البشير النذير نبينا محمد المبعوث

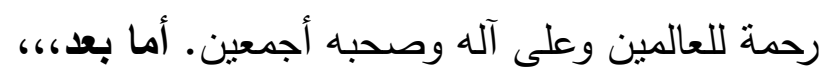

فكلمـا قرأت القرآن الكريم وتدبرته تظهر لـي عظمته وإعجـازه، وممـا أكده المـولى عـز وجـل في كتابـه الكـريم قدرتـهـ جـل وعـلا على إحصـاء الحركـات والسكنات لخلقه وعلمها بما يفعلون في سرهم وجهرهم، واطِّلاعه على ما يقولون بألسنتهم وما يُكنّون في صدورهم، وإحصائه كل ذلك على عباده في صور شتى،

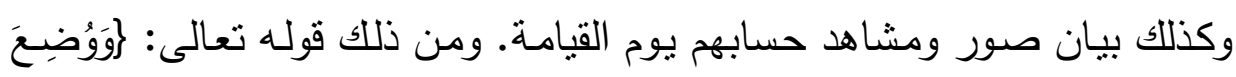

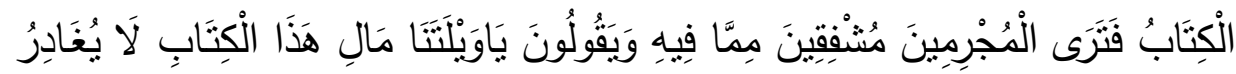

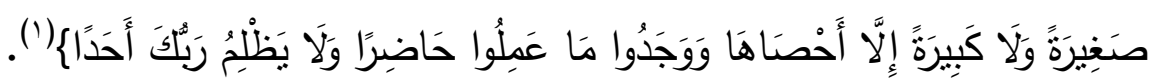
ففي هذه الآية يقول الحق عن أحوال المحاسبين يوم القيامة مالِ هذا الكتاب لا يغادر صغيرة ولا كبيرة إلا أحصاها، فالكتاب أحصى كل شيء عيء وبعد ذلك يقول

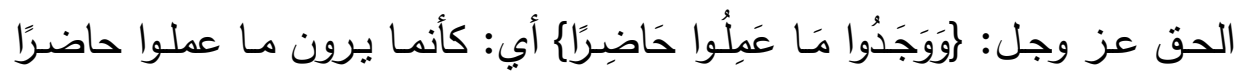

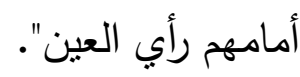




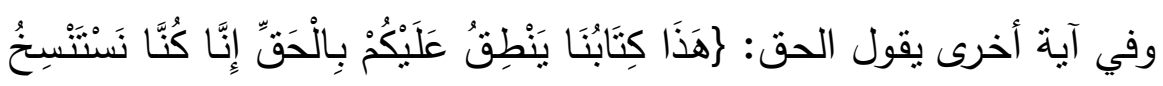

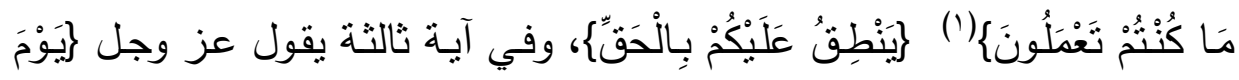

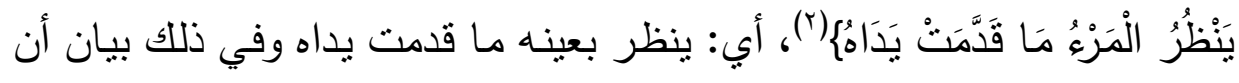

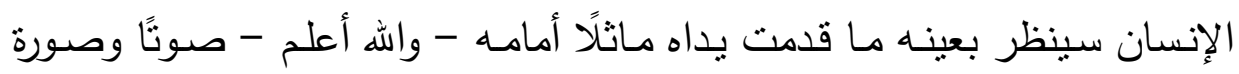
وكتابة، وكما يختم الله على أفواه بني آدم المحاسبين وتتكلم أيديهم وتشهـد أرجلهم

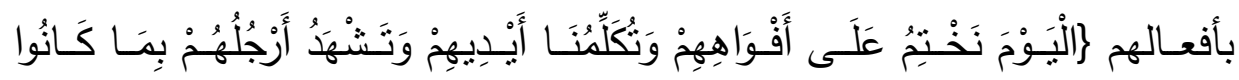

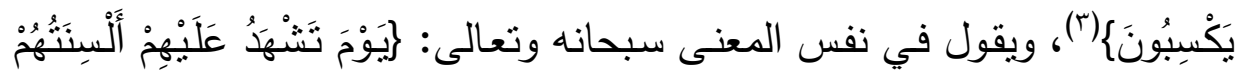

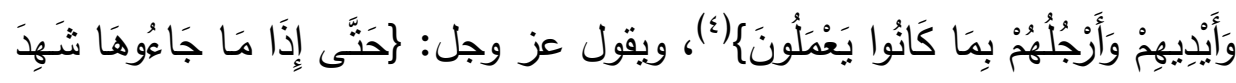

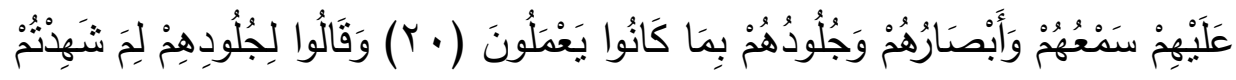

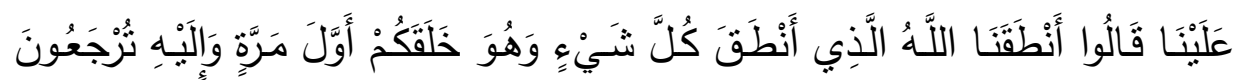

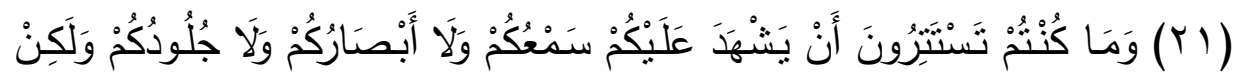

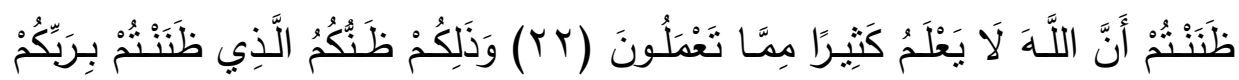

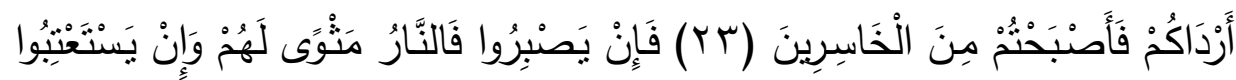

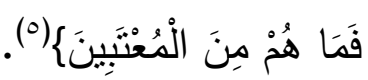
ففي هذه الآيات يبين عز وجل صور الحساب كلها تقيم الحجة على الخلق

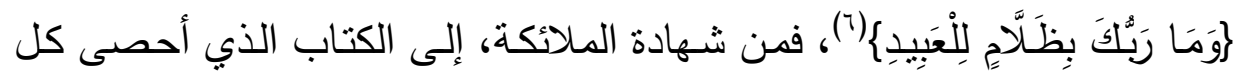
شيء على الإنسان، إلى شهادة الجوارح على العبد في فعله، إلى نظر الإنسان

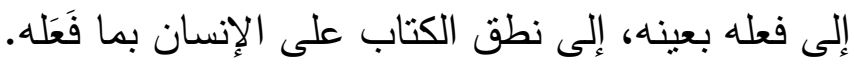

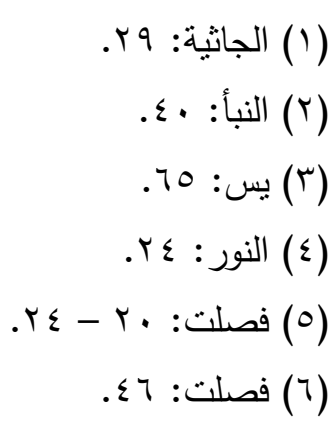




\section{د · فه صالح الخنه}

وورد في صحيح مسلم وابن حيان عن أنس بن مالك: "كنا عند رسول الله صلى الله عليه وسلم فضحك فقال: (هل تدرون مما أضحك)؟ قلنا: الله ورسوله أعلم قال: من مخاطبة العبد ربه يقول: يا رب ألم تجرني من الظلم؟ قال: يقول: بلى، قال: فيقول: فإني لا أجيز على نفسي إلا شـاهدا مني، قال: فيقول: كفى نهى بنفسك اليوم عليك شهيدا، وبالكرام الكاتبين شهودا، قال: فيختم على فيه، فيقال لأركانـه: انطقي، قـال: فتنطق بأعماله، قـال: ثم يخلى بينـه وبين الكـلام، قـال فيقول: بعدا لكن وسحقا، فعنكن كنت أناضل"(1). ففي هذا الحديث بيان لما ورد في القرآن الكريم من صور حساب الناس يوم القيامة، بشهادة الجوارح على الإنسان بما قامت بـه من ذنوب ومعاصٍِ، وتقصيل ذلك سيأتي في هذا البحث بفضل الله. وقد أوردنـا كـلام المفسرين على الروايـات، وفي هذا البحـث ذكرنـا صـور الحساب على الخلق يوم القيامة ومشاهد السؤال، وفي ذلك عبرة ليعلم كل مسلم أن حركاته وسكناته وأقواله ونياته وجهره وسره مكشوف أمسام ربه، فيتقي الله في

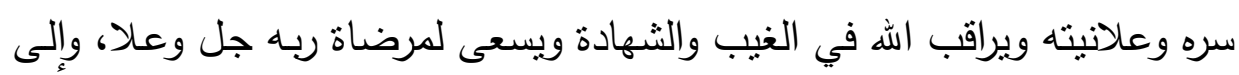
التعرض إلى رحمته طلبًا لرضاه والجنة وتجنبًا لسخطه والنار .

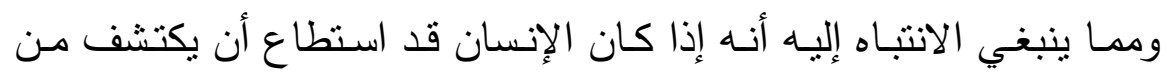

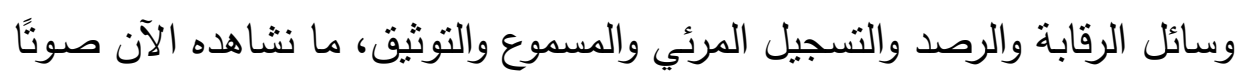

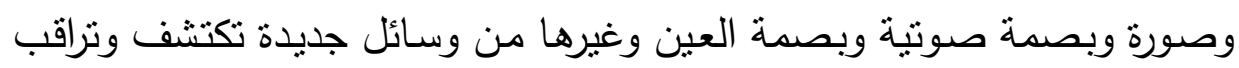
وتسجل كل شاردة وواردة في مجالها، وله المثل الأعلى، فكيف بالله القوي القادر لا شك أن ذلك يؤكد لنا أن الحساب يوم القيامـة سيكون أدق وأوثق، فعلى المسلم أن يتقي الله في نفسه ويحرص ألا يراه الله في موضع لا يرضاه، أو في وضع لا لأل يحبه، أو أن يرى في صحيفته يوم العرض ما يندم عليه ولات حين مندم.

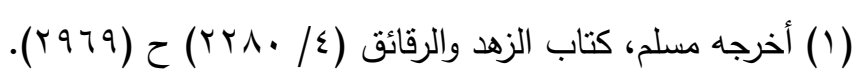

$$
\begin{aligned}
& -\varepsilon q \uparrow-
\end{aligned}
$$


نسأل الله أن يعيننا على ذكره وشكره وحسن عبادته، ويرزقنا خشيته في السر

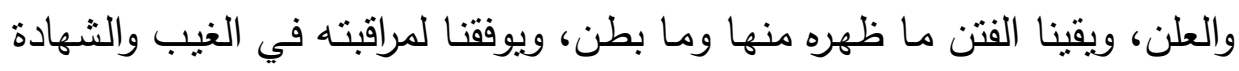

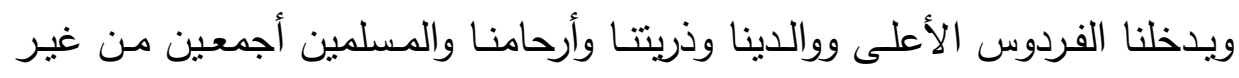
حساب ولا عذاب، إنه عفو كريم.

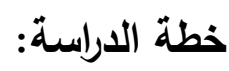

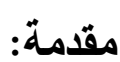

المبحث الأول: الحساب وصوره في القرآن الكريم.

المطلب الأول: مفهوم الحساب في القرآن الكريم.

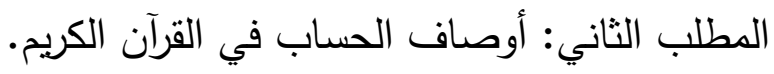

المبحث الثاني: العرض. المبان

المطلب الأول: معنى العرض في اللغة.

المطلب الثاني: دلالات العرض في القرآن الكريم.

المبحث الثالث: مفهوم السؤال يوم القيامة.

المبحث الرابع: الإحصاء والكتابة.

المطلب الأول: الإحصاء.

المطلب الثاني: الكتابة.

المبحث الخامس: الوزن والميزلان.

المطلب الأول: الوزن والميزان في اللغة.

المطلب الثاني: الوزن والميزان في القرآن والسنة.

المبحث السادس: إثهاد الجوارح.

المبحث السابع: أهل اليمين وأهل الثمال.

المبحث الثامن: النظر إلى الأعمال ونطق الكتاب.

المبحث التاسع: صور من الحساب الخاص.

خاتمة

المصادر والمراجع 
د. فهر صالح الخنه ل

المبحث الأول

الحساب وصوره في القرآن الكريم

المطلب الأول: مفهوم الحساب في القرآن الكريم:

تدور معاني الحساب في القرآن الكريم على عملية المساءلة التي تحصل فلئل للعبد في الآخرة ويجازى بحسبها فتعرض للعبد يوم القيامة حسناته وسيئاته ثم يجازى بحسب ما ينتهي إليه الميزان.

يقال: (حاسبه محاسبة وحسابا: أحصى عليه أعماله للجزاء عليها فحاسبناها:

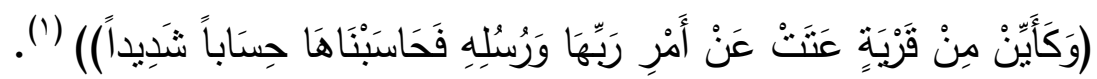

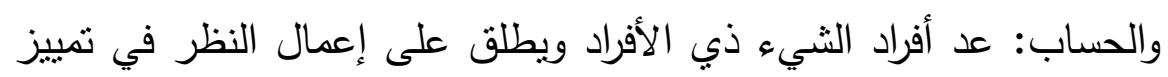

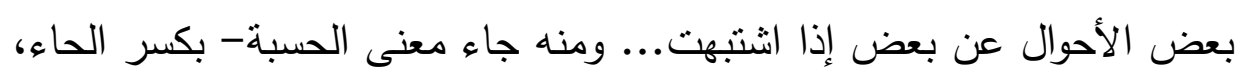

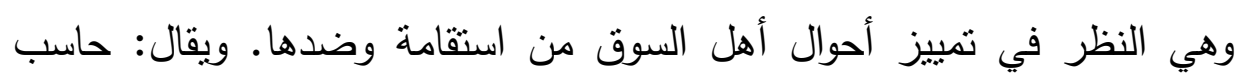
فلانا على أعماله إذا استقراها وتتبعها. قال النابغة:

\section{يحاسب نفسه بكم انشتراها}

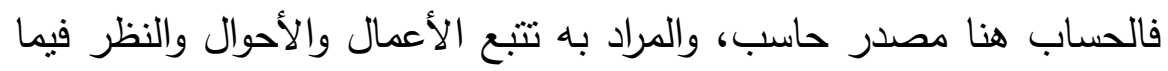

$$
\text { تقابل به من جزاء (؟) . }
$$

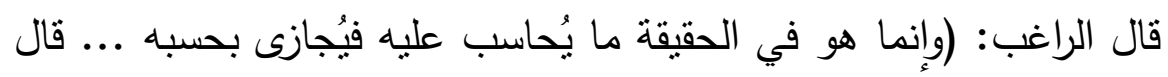

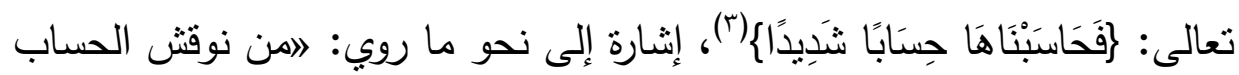

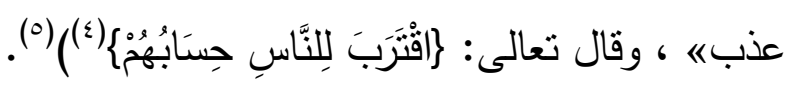

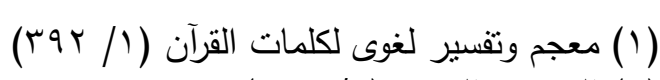

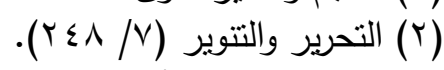

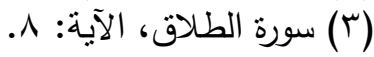

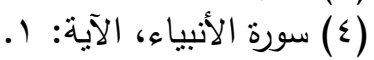

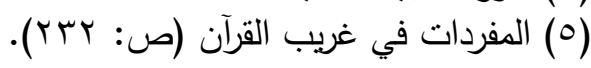


وقال القرطبي: (معنى الحساب: تعريف اله عباده مقادير الجزاء على الهى أعمالهم، وتذكيره إياهم بما قد نسوه، بدليل قوله تعالى: يوم يبعثهم الله جميعا فينبئهم بما عملوا أحصاه الله ونسوه) (').

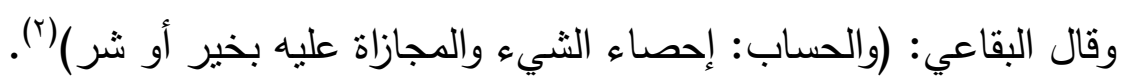

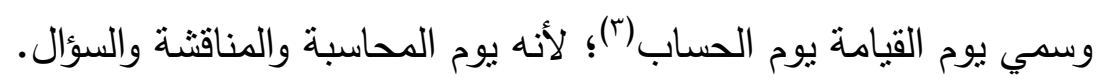

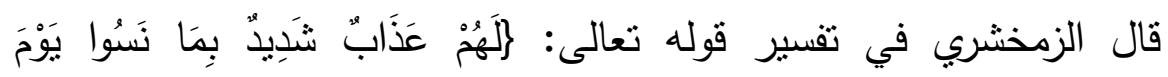

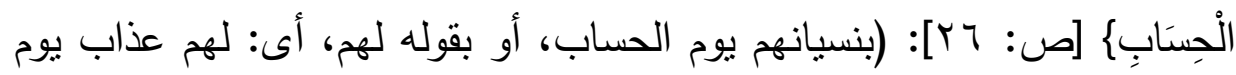
القيامة بسبب نسيانهم وهو ضلالهم عن سبيل الهه) (؛).

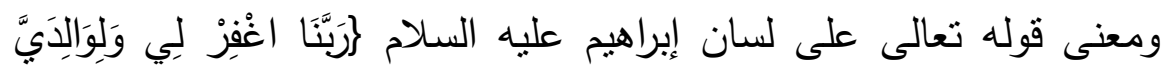

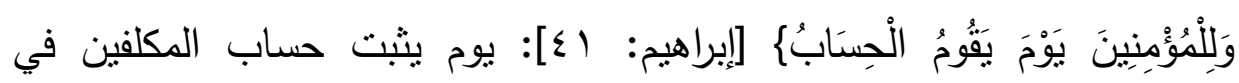

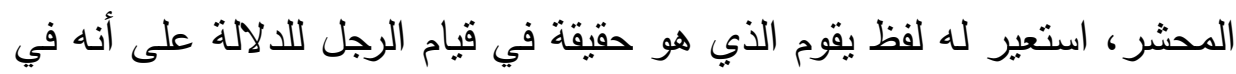

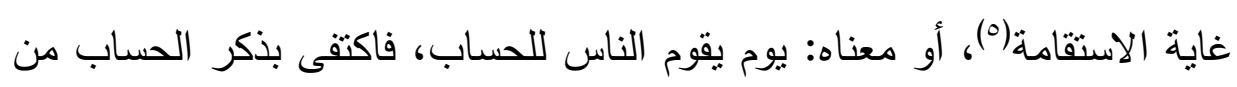
ذكر الناس، إذ كان مفهوما معناه(؟). قال الرازي: (وفي قوله: يوم يقوم الحساب قولان: الأول: يقوم أب يثبت وهو الئان

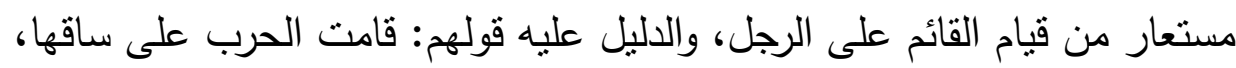

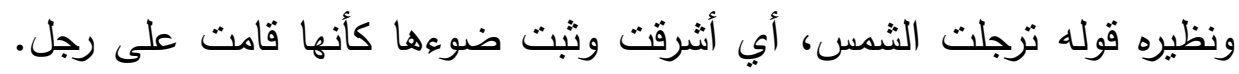

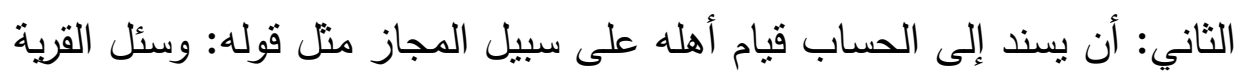

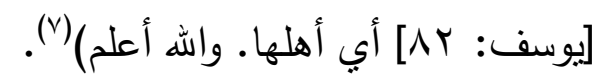

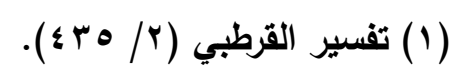

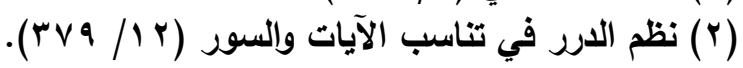

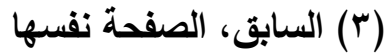

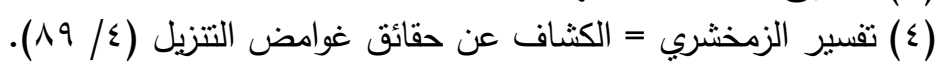

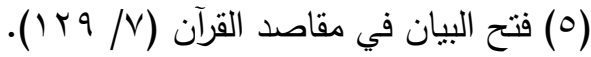

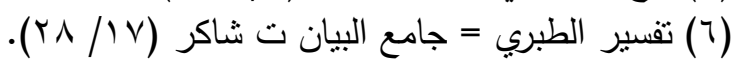

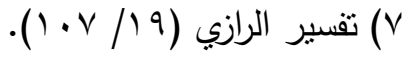

$$
\begin{aligned}
& -\{97-
\end{aligned}
$$




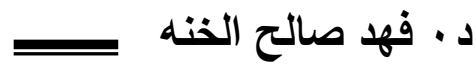

وقال ابن عطية في قوله تعالى : إِنَّ اللَّهَ سَرِيعُ الْحِسَابِ

(قبل معناه: سربع إنيان بيوم القيامة، وهو يوم الحساب، فالحساب إذا سربع إذ كل آت قريب، وقال قوم: سَرِيعُ الْحِسابٍ أي إحصاء أعمال العباد وأجورهم وآثامهم،

إذ ذلك كله في عمله لا يحتاج فيه إلى عد وروية ونظر كما يحتاج البشر)('). المطلب الثاني: أوصاف الحساب في القرآن الكريم.

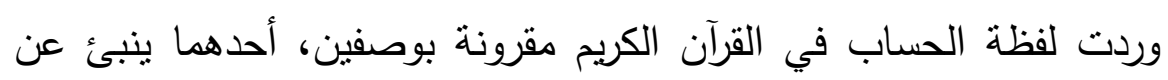
سوء مصير صاحبه إذ هو الحساب السيِّئ الذي يناقش صاحبه الحساب، والثاني ينبئ عن فضل الله تعالى على من يحاسبه إذ يتجاوز عن سيئاته وفيما يلي تقصبل ذلك:

الوصف الأول: الحساب السيِّئ أو الشديد

وقد ورد هذا الوصف للحساب في ثناث آيات.

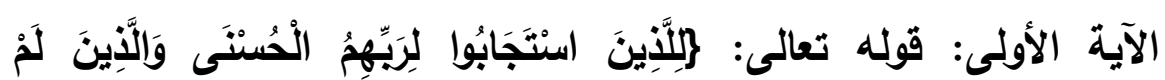

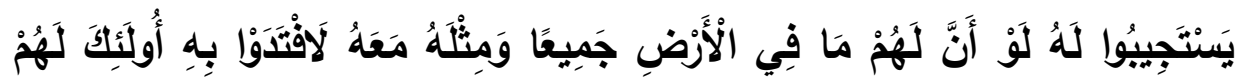

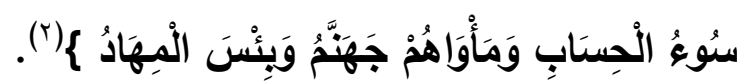
وفي هذه الآية يتحدث المولى تبارك وتعالى عن الذين لم يستجيبوا لدعوة

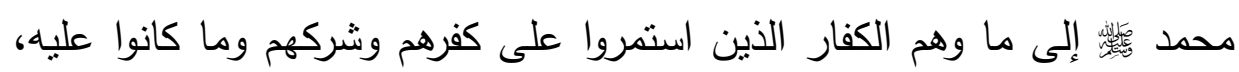
ويصف حالتهم في الآخرة وأنه لو كان عندهم ضعف ما في الأرض من أموال

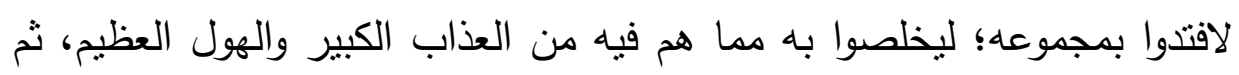

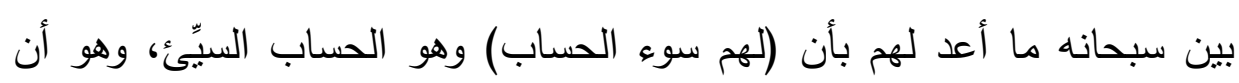

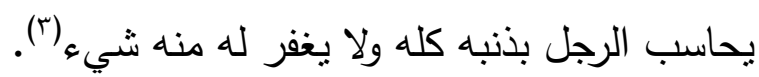

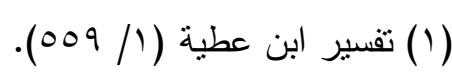

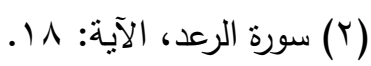

$$
\begin{aligned}
& \text { (ץ) فتح البيان في مقاصد القرآن (Y/ ع ؟ ). }
\end{aligned}
$$


قال القرطبي: (أي لا يقبل لهم حسنةُ، ولا يُتجاوز لهم عن سيئة) ('). وقال ابن كثير: (يناقثون على النقير والقطعير، والجليل والحقير، ومن لهن

$$
\text { نوقش الحساب عذب)(r). }
$$

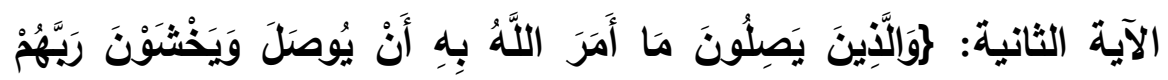

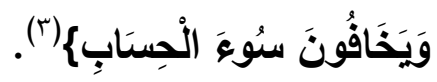

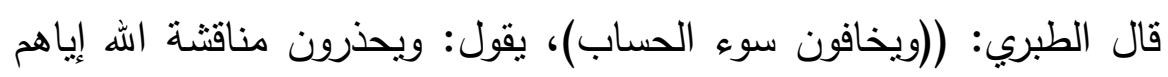

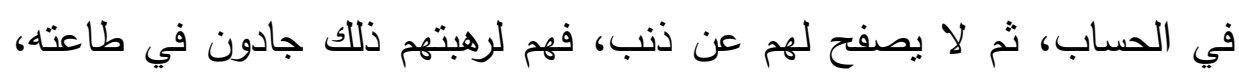

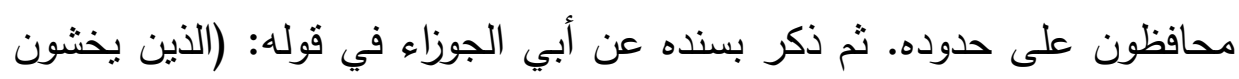

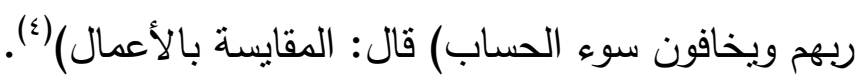

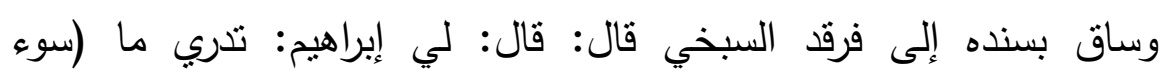

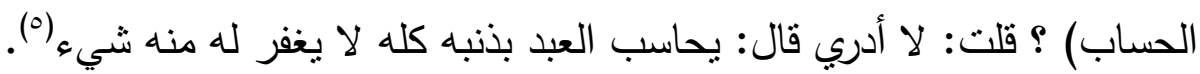

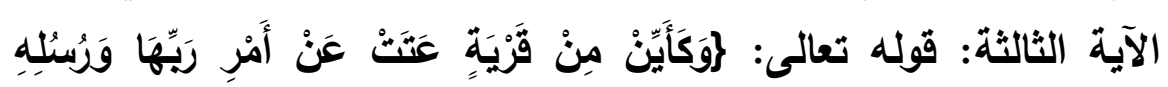

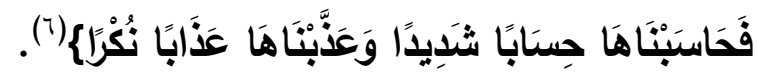

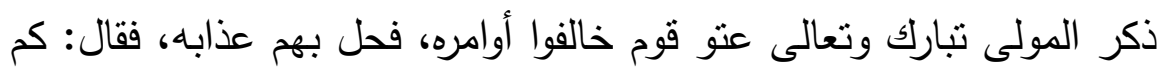

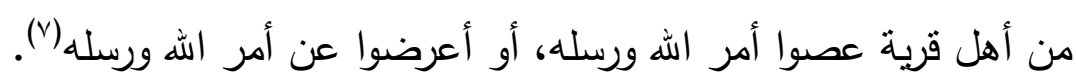

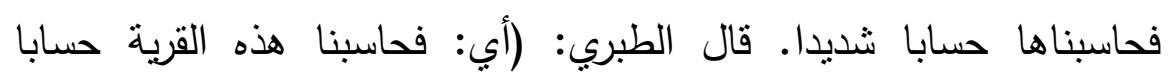

استقصينا فيه عليهم، لم نعف لهم فيه عن شيء، ولم نتجاوز فيه عنهم) (^ان.

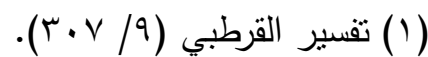

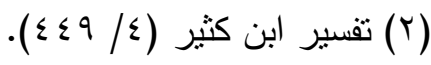

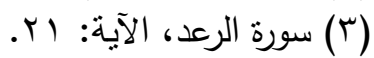

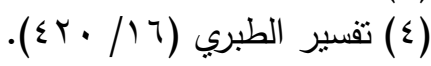

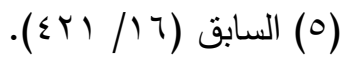

$$
\begin{aligned}
& \text { (T) سورة الطلاق، الآية: A. }
\end{aligned}
$$

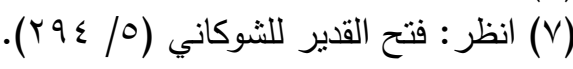

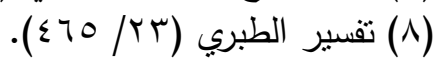




\section{د · فه صالح الخنه}

الوصف الثاني: الحساب اليسير.

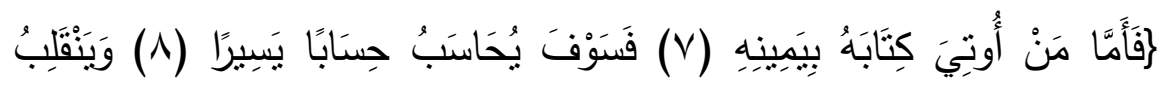

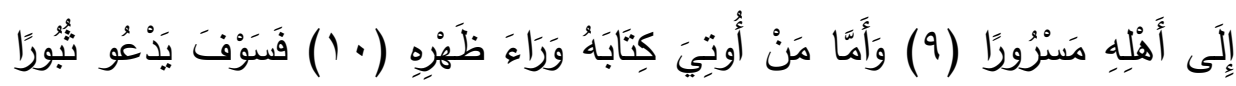

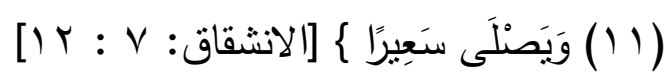

تتحدث هذه الآيات عن بعض السعداء في الآخرة وهو من بؤتى كتابه بيمينه فتذكر أن الهه سبحانه وتعالى سيحاسبه الحساب اليسير، أي الحساب السهل الهين الذي لا مناقثنة فيه؛ لأنه يخفر ذنوبه ولا يحاسبه عليها، فيعرض عليه سيئاته ثم يغفرها الله له (1).

قال الطبري: (فسوف يحاسب حسابا يسيرا) بأن ينظر في أعماله، فيغفر له

$$
\begin{aligned}
& \text { سيأها، ويجازى على حسنها)(؟). } \\
& \text { ثم ذكر الآثار عن ذلك ومنها: }
\end{aligned}
$$

هن عائشة، قالت: سمعت النبي صلى الله عليه وسلم يقول: "اللهم حاسبني حسابا يسيرا"، قلت: يا رسول الله ما الحساب اليسير؟ قال: "أن ينظر في سيئاته فيتجاوز عنه، إنه من نوقش الحساب يومئذ هلك"(؟). * وعن ابن زبد قال: (فسوف يحاسب حسابا يسيرا) قال: الحساب اليسير: الذي يغفر ذنوبه، ويتقبل حسناته، وبسير الحساب الذي بعفى عنه، وقرأ:

(1) فتح البيان في مقاصد القرآن (10/ ب ـ ( ).

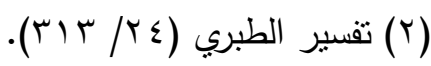

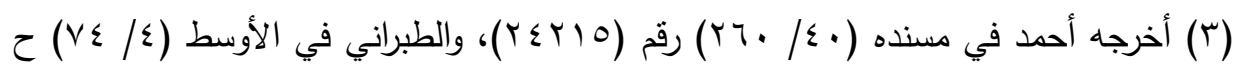

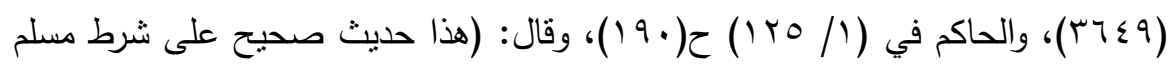

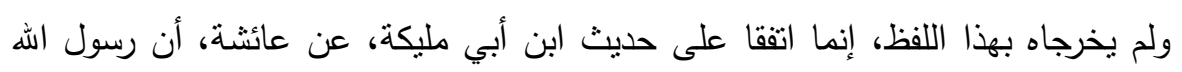
صلى اله عليه وسلم، قال: المن نوقش الحساب عذبه، وقال الذهبي: (على شرط إنى مسلم). 
(ويخافون سوء الحساب)، وقرأ: (أولئك الذين نتقبل عنهم أحسن ما عملوا ونتجاوز

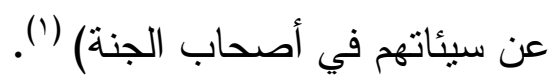
والخلاصة: أن الصورة الجامعة للحساب في القرآن الكريم هي صورة الحساب آلهاب

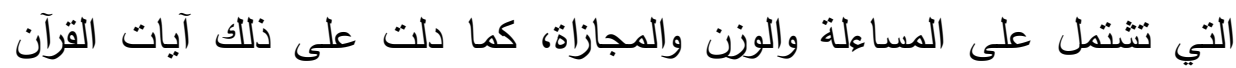

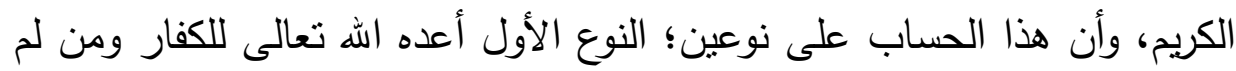

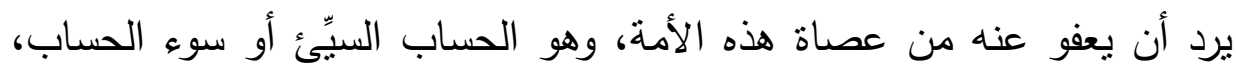

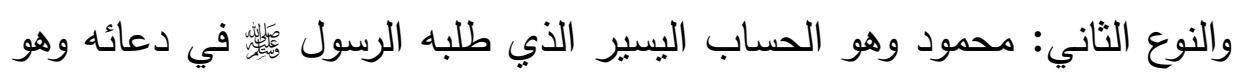
أن ينظر في سيئاته فيتجاوز عنه. 


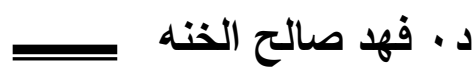

\section{المبحث الثاني}

\section{العرض}

المطلب الأول: معنى العرض في اللغة.

العرض هو إظهار الثيء وإبرازه يقال: عرضت الثيء فئهض فأعرض، أي أظهرته

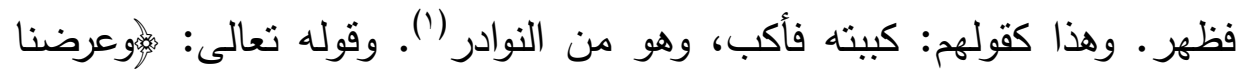

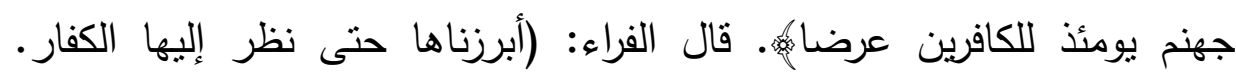

$$
\text { وأعرضت هي، أي استبانت وظهرت)(؟). }
$$

المطلب الثاني: دلالات العرض في القرآن الكريم.

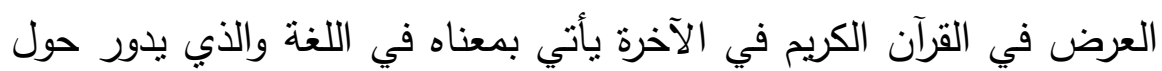
الظهور والبروز، ويتتوع ويتعدد باختلاف الموقف، فهناك العرض العام لإظهار

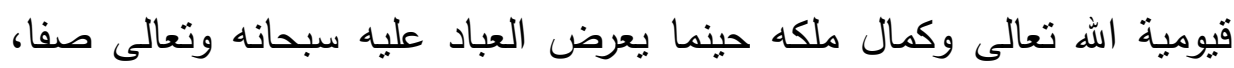

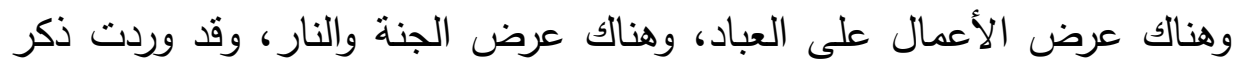

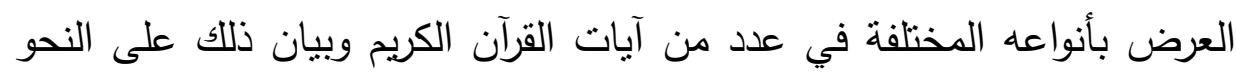

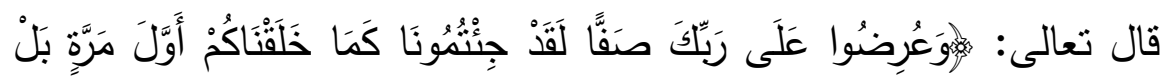

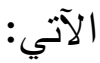

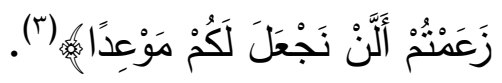

تبين هذه الآية أنه بعد أن يُحشر الخلائق يوم القيامة، فإنهم جميعا يعرضون

$$
\text { على الله تعالى يوم القيامة صفا. }
$$

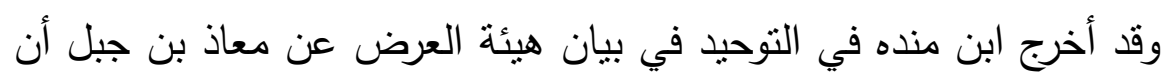

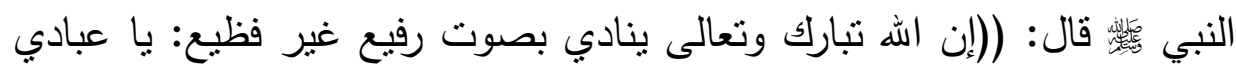

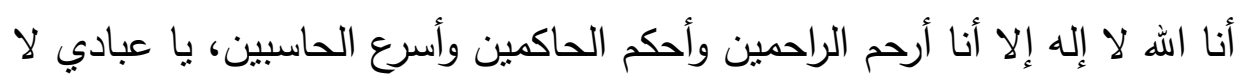

$$
\begin{aligned}
& \text { (1) الصحاح (T/ ع (1) (1). }
\end{aligned}
$$

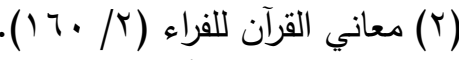

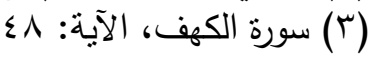




\section{صور الحساب}

خوف عليكم اليوم ولا أنتم تحزنون، أحضروا حجتكم وشروا جوابكم فإنكم مسؤولون

محاسبون، يا ملائكتي أقيموا عبادي على أطراف أنامل أقدامهم للحساب)(') ('). قال الرازي: (لما ذكر الله تعالى حشر الخلق ذكر كيفية عرضهم، فقال: عرضوا على ربك صفا، و ... في تفسير الصف وجوه. أحدها: أنه تعرض الخلق كلهم على الله صفا واحدا ظاهرين بحيث لا يحجب بعضهم بعضا ... وثانيها: لا يبعد أن يكون الخلق صفوفا يقف بعضهم وراء بعض مثل الصفوف المحيطة بالكعبة التي يكون بعضها خلف بعض، وعلى هذا التقدير فالمراد من قوله:罗

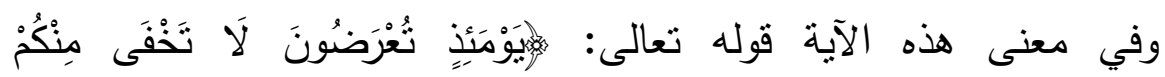

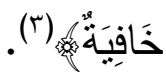

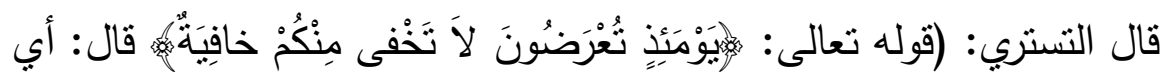
تعرضون على الحق عزَّ وجلَّ، فيحاسبكم بأعمالكم، لا يخفى عليه من أعمالكم شيء، كل ذلك معروف محصي عليكم في علمه السابق، فيسأله عن جميع ذلك)(๕)

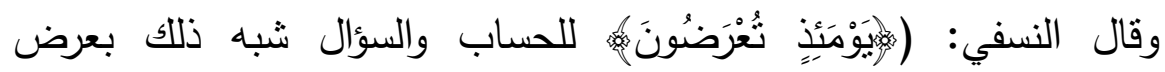

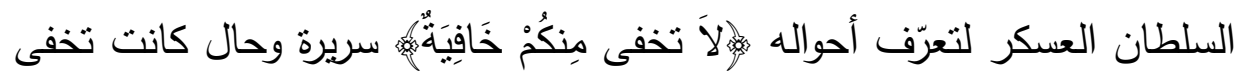
في الدنبا)(ن)

(1) عزاه القرطبي لابن منده في كتاب التوحيد، وقال: (هذا الحديث غاية في البيان في تفسير

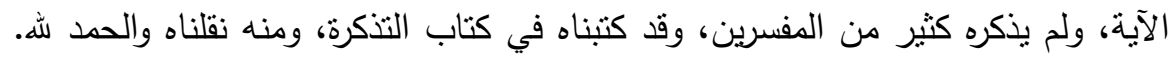

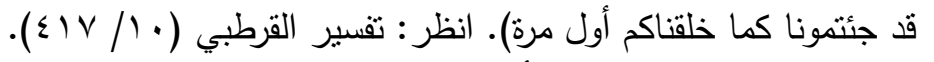

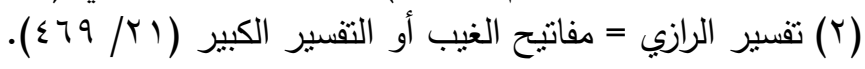

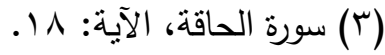

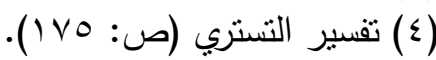

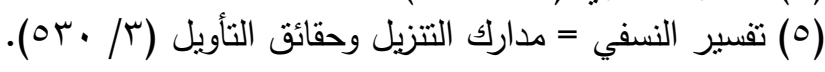




\section{د · فر صالح الخنه}

وكما يعرض العباد للحساب فإن النار تعرض على الكافرين يوم القيامة قال تعالى: حتى يشاهدها الكفار، وفي ذلك وعيد عظيم لهم بسبب ما يحصل معهم عند

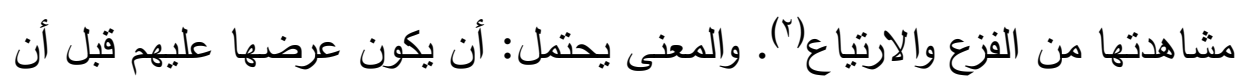

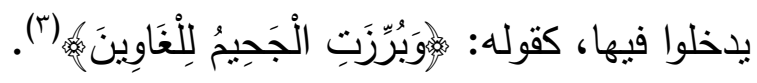
قال الطبري: (وقوله:

جهن يوم ينفخ في الصور ، فأظهرناها للكافرين بالله، حتى يروها ويعاينوها)(؛). ثم روى بسنده إلى ابن مسعود قال: يقوم الخلق لله إذا نفخ في الصور ، قيام رجل واحد، ثم يتمثل الله عز وجل للخلق فما يلقاه أحد من الخلائق كان يعبد من دون الله شيئا إلا وهو مرفوع له يتبعه، قال: فيلقى اليهود فيقول: من تعبدون؟ قال: فيقولون: نعبد عزبرا، قال: فيقول: هل يسركم الماء؟ فيقولون نعم، فيربهم جهنم

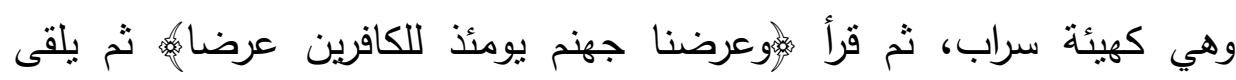
النصارى فيقول: من تعبدون؟ فيقولون: نعبد المسيح، فيقول: هل يسركم الماء، فيقولون نعم، قال: فيربهم جهنم وهي كهيئة السراب، ثم كذلك لمن كان يعبد من

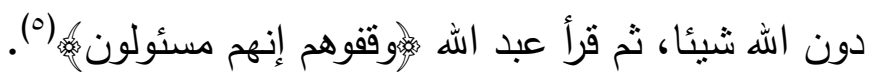

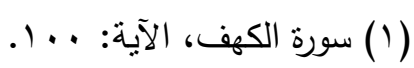

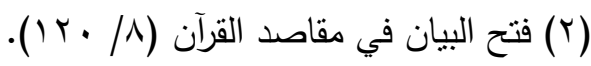

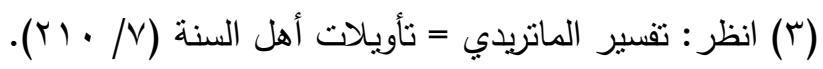

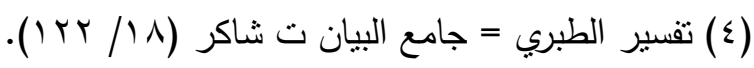

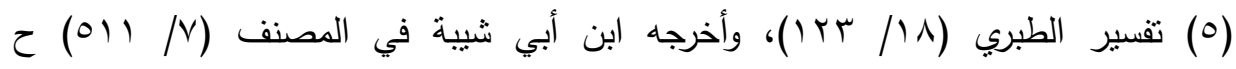

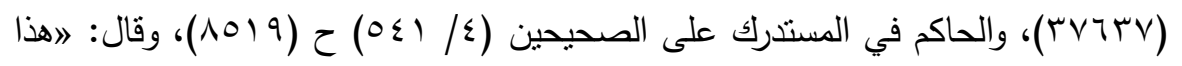

$$
\begin{aligned}
& \text { حديث صحيح على شرط الثيخين، ولم يخرجاهه ووافقه الذهبي. } \\
& -0 . r-
\end{aligned}
$$




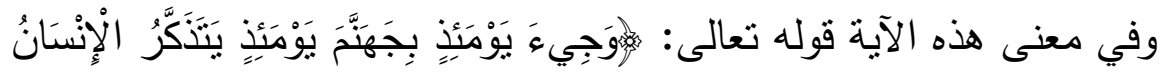

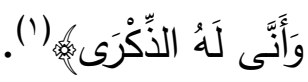

قال الرازي: (قال جماعة من الدفسرين: جيء بها يوم القيامة مزمومة

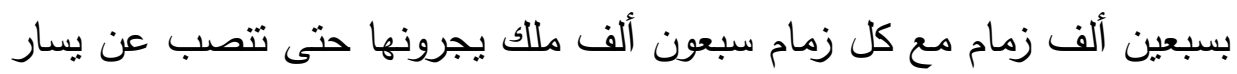

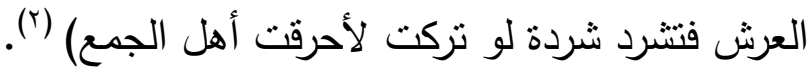

وما ذكره الرازي يؤيد بعضه ما جاء في الحديث عن عبد الله، قال: قال

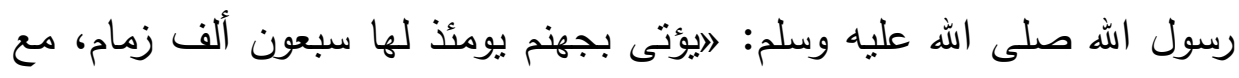

$$
\text { كل زمام سبعون ألف ملك يجرونهاها"(r). }
$$

ويحتمل أن يكون العرض كناية عن التعذيب بها بعد ما أدخلوا فيها كقوله

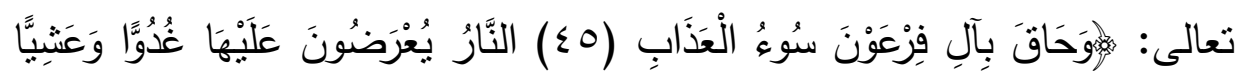

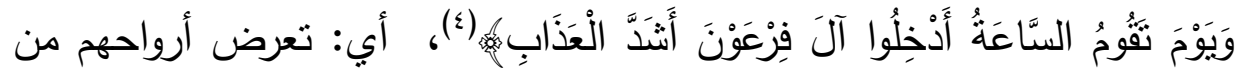

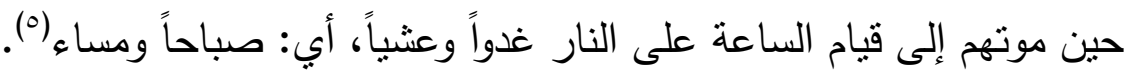

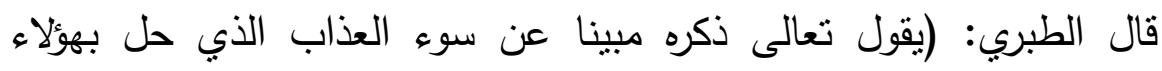

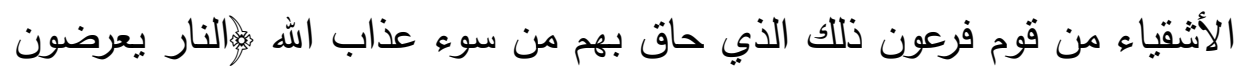

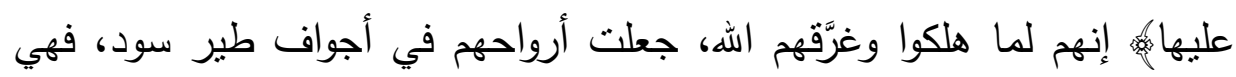

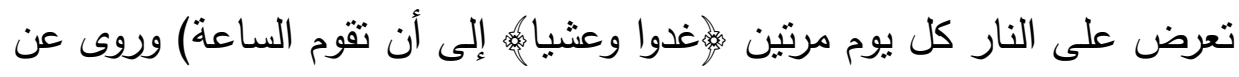

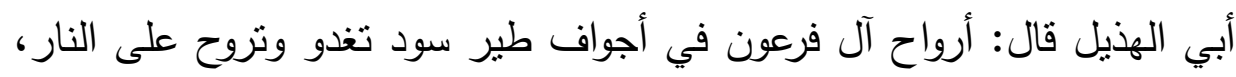
وذللك عرضها. وقيل: عنى بذللك: أنهم يعرضون على منازلهم في النار تعذيبا لهم

$$
\text { غدوا وعشيا('). }
$$

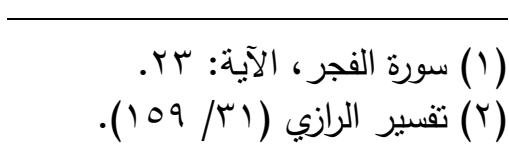

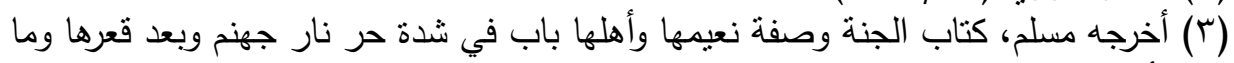

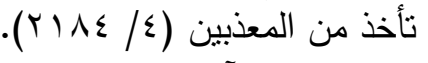

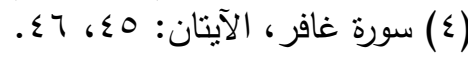

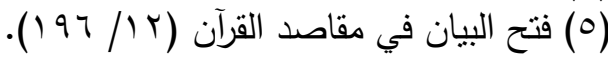

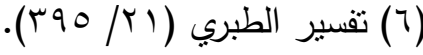




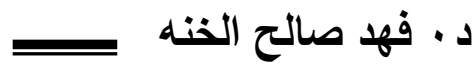

وروى عن قتادة زهالنار يعرضون عليها غدوا وعشياهُ قال: يعرضون عليها

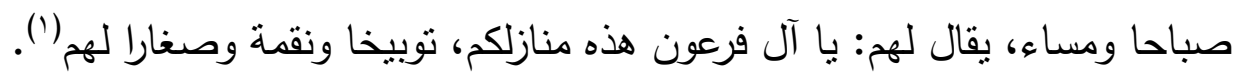

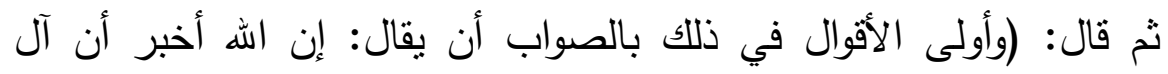

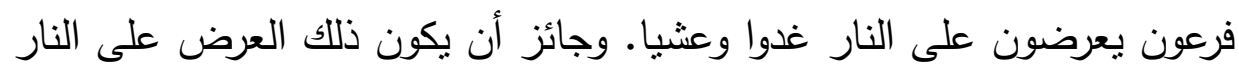

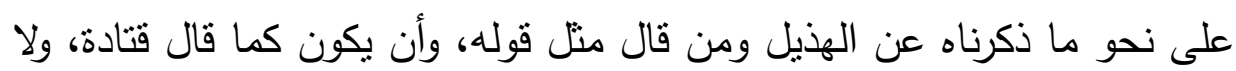

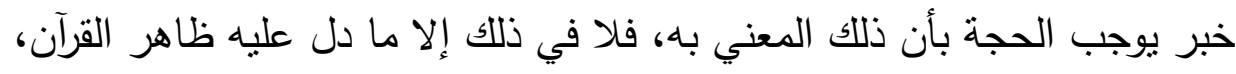

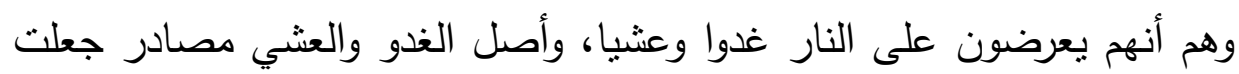

لكن الوجه الثاني يؤيده ما جاء في السنة النبوية عن عبد الله بن عمر رضي النها

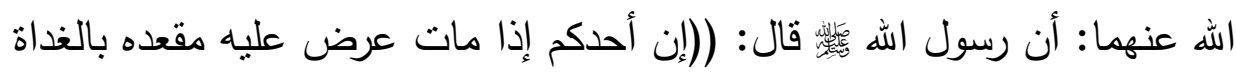

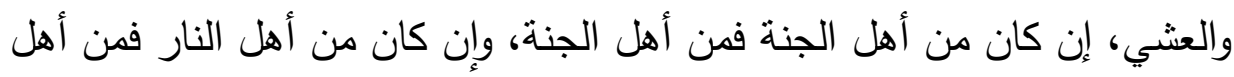

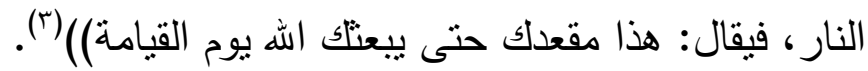
قال ابن بطال: (قال القاضى ابن الطيب: اتفق المسلمون أنه لا غدو ولان النال

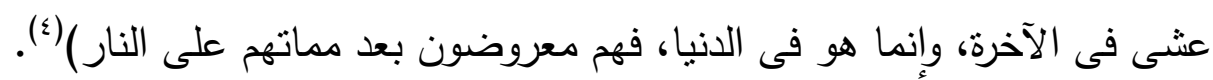

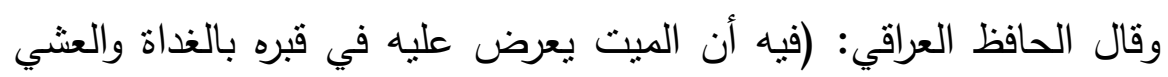

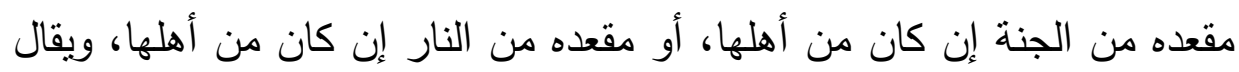

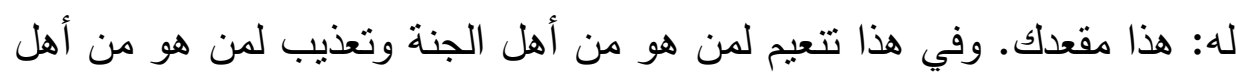

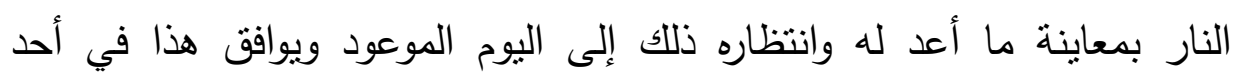

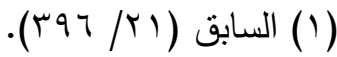

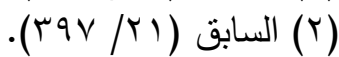

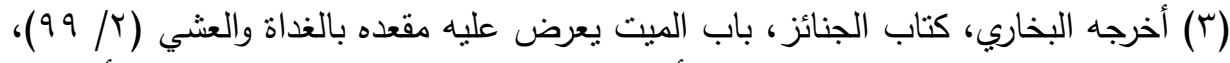

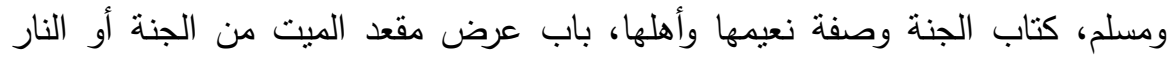

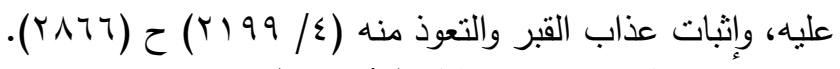

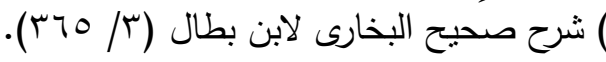




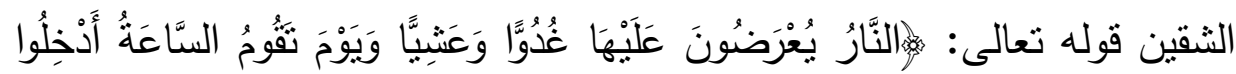

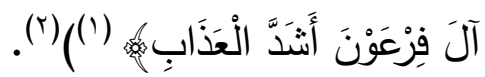

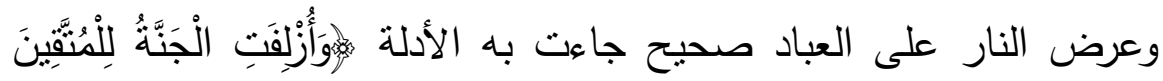

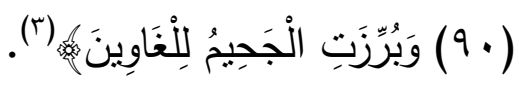

فالجنة تقترب وتدنو من الصالحين بحيث يثاهدونها من الموقف، ويققون

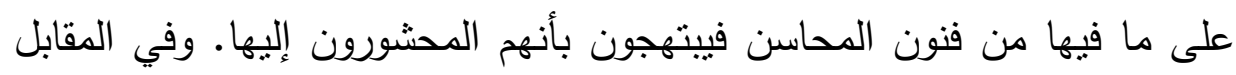
تبرز النار للكافرين في الموقف بحيث برنها فئها مع ما فيها من أنواع الأحوال الهائلة، فيكون غما لهم زيادة في العقاب على كفرهم (๕).

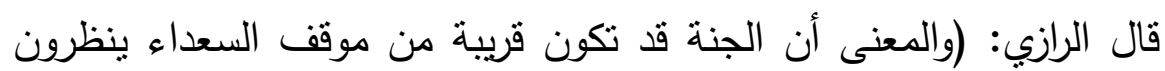

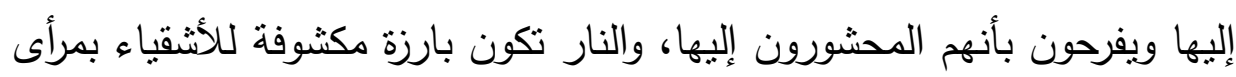

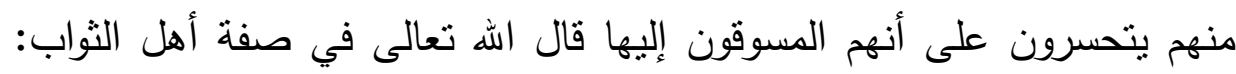

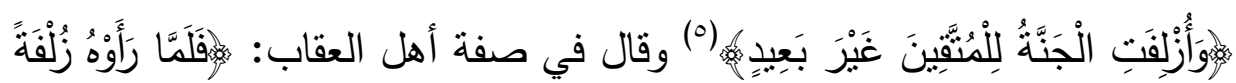

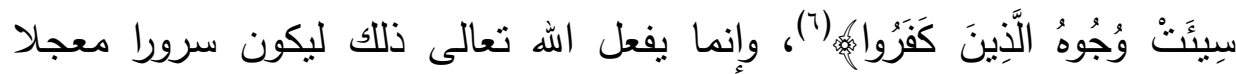

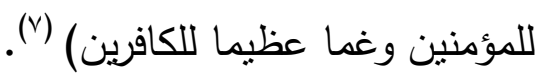
وقال القرطبي: (تظهر جهم لأهلها قبل أن يدخلوها حتى بستشعروا الروع

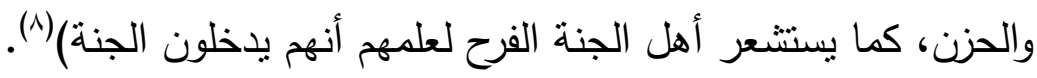

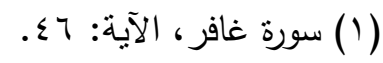

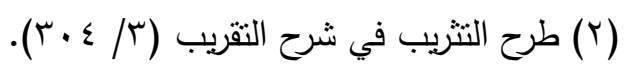

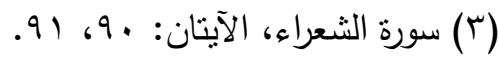

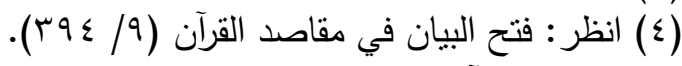

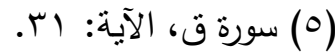

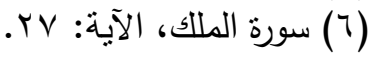

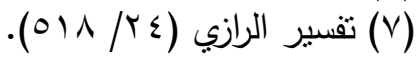

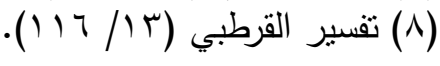




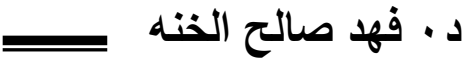

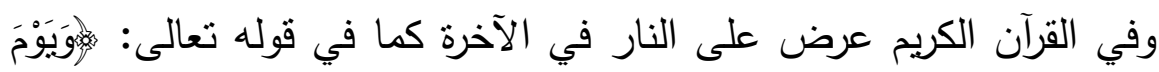

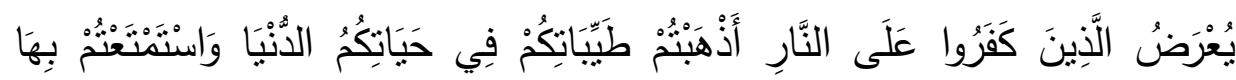

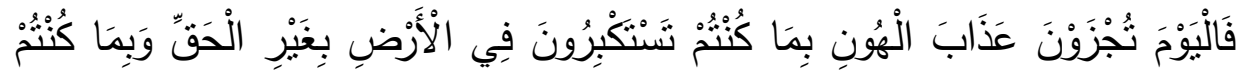

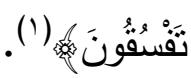

فهذه الآية تفيد أن للكفار عرضا بعد الحساب يعذبون من خلاله، وفي تفسير هذا العرض وجوه ذكرها المفسرون:

أولها: النظر إلى النار ويكون المعنى: اذكر لهم يا محمد يوم ينكثف الغطاء فينظرون إلى النار ويقربون منها (r). وإثثاني: يعرضون أبي: يعذبون، وهو عرض الفئرن المباشرة كما نقول عرضت

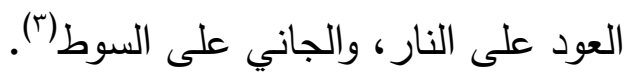

الثالث: قيل في الكلام قلب. والمعنى: تعرض النار، النار عليهم (\&). والذي أراه راجحا أن يكون معنى العرض على حقيقته فهو أبلغ في الدلالة؛

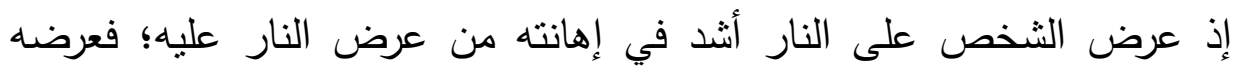

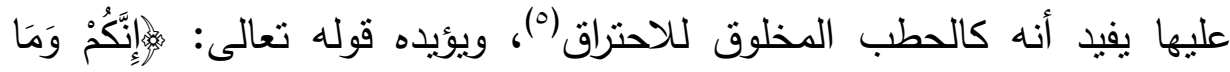

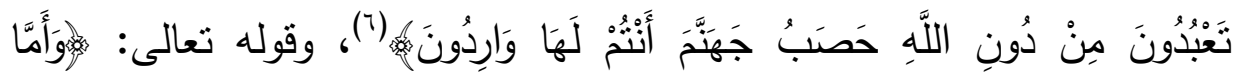

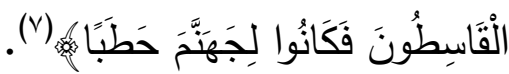

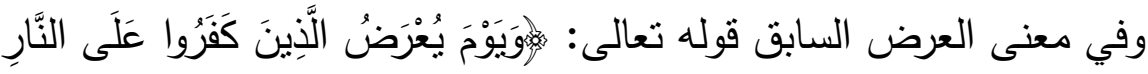

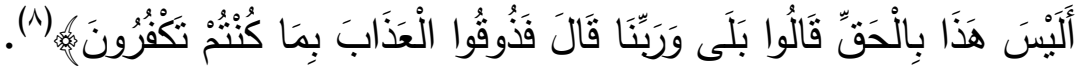

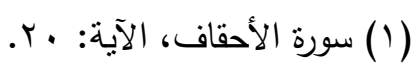

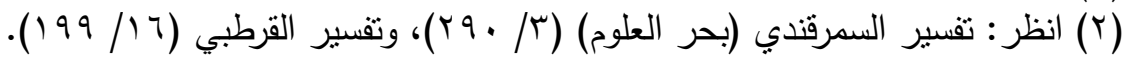

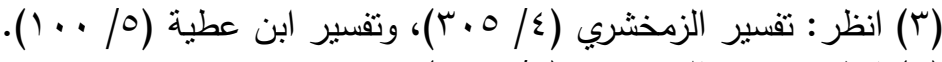

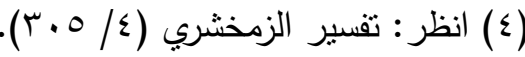

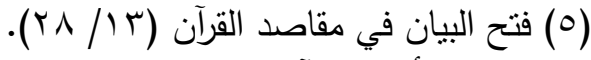

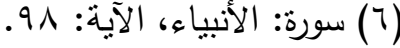




\section{المبحث الثالث}

\section{مفهوم السؤال يوم القيامة}

تكررث لفظة السؤال ومشتقاتها في القرآن الكريم، وهي غالبا تدور حول سؤال

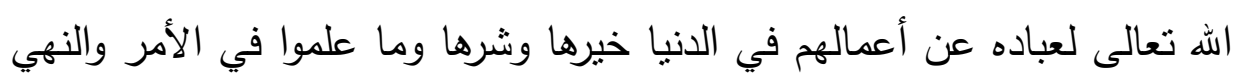

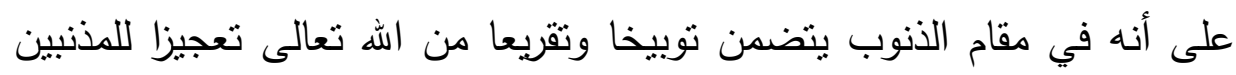

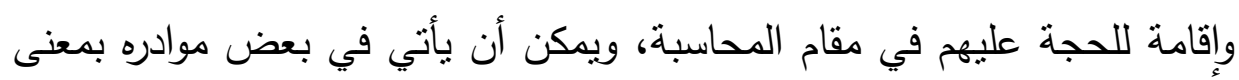
عموم الدحاسبة التي سبق عرضها فيكون كنية عن عملية المحاسبة في الآخرة

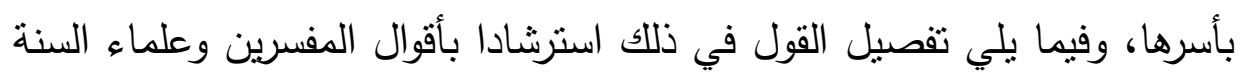

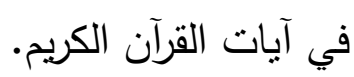

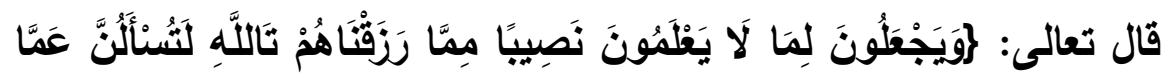

\section{كُنْتُمْ تَفتْرَوَنَ}

تتحدث هذه الآية الثريفة عن الكفار وكونهم يجعلون لما لا بعلمون حقيقته

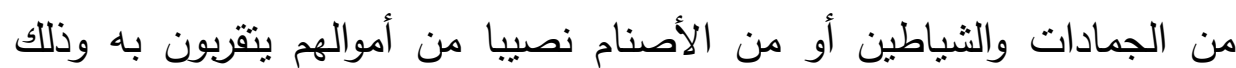

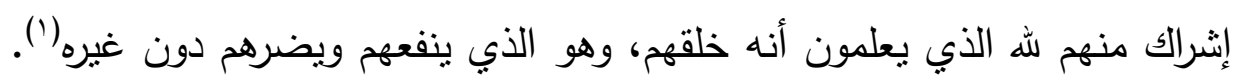

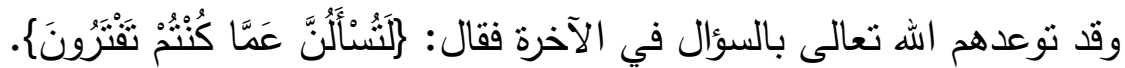

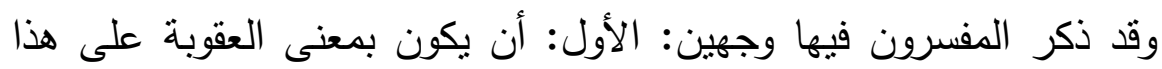
الافتراء، والثنانية: هي السؤال على معنى التوبيخ والتقريع.

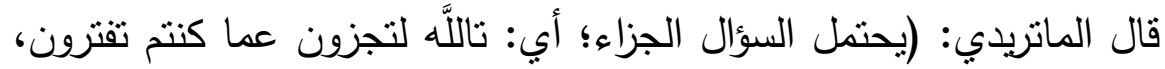

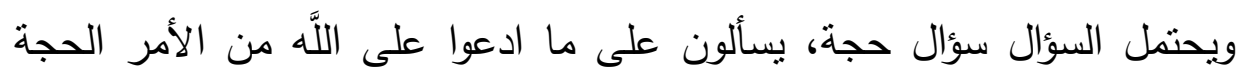

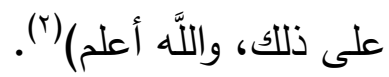

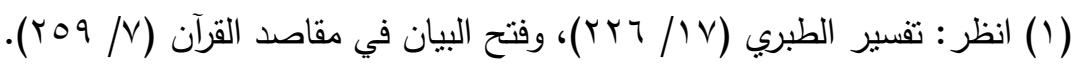

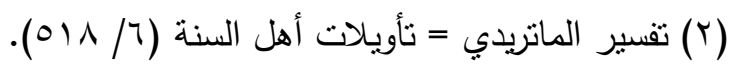

$$
\begin{aligned}
& -0.1-
\end{aligned}
$$




\section{د. ف فه صالح الخنه}

وقال الزجاج: (أي تاله لتسألن عنه سؤال توبيخ حتى تعترفوا به على

أنفسكم، وتلزموا أنفسكم الحجة) (').

والوجه الأول أرجح إذ السؤال نوعان: أحدهما سؤال التوبيخ والتقربع وهو من أنواع العذاب، والثاني هو سؤال الاستخبار والاستعلام(؟). فالسؤال في هذه الآية:

سؤال إلزام الحجة، لا سؤال الاستعلام والاستقهام (r).

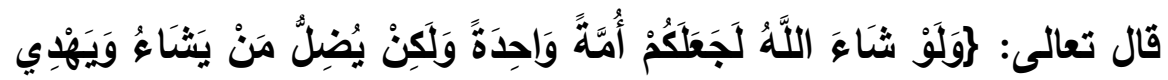

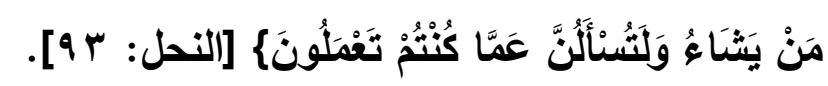

تتحدث الآية الكريمة عن حكمته تعالى في أنه لم يجعل الناس جميعا جماعة

واحدة، وأهل ملة واحدة لا يختلفون ولا يفترقون، ولكنه تعالى ذكره خالف بينهم، فجعلهم أهل ملل شتى، بأن وفق هؤلاء للإيمان به، والعمل بطاعته، فكانوا مؤمنين، وخذل هؤلاء فحرمهم توفيقه فكانوا كافرين، والحكم في ذلك أنه سبحانه سيجازي الجميع يوم القيامة ويحاسب الناس على أعمالهم: قال الطبري: (وليسألنكم الله جميعا يوم القيامة عما كنتم تعملون في الدنيا فيما أمركم ونهاكم، ثم ليجازبنكم جزاء المطيع منكم بطاعته، والعاصي لله

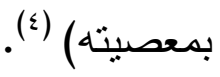

فمعنى السؤال هنا أن كل إنسان سيسأل يوم القيامة عن أفعال جوارحه، فيقال له: لم سمعت ما لا يحل للك سماعه؟ ولم نظرت إلى ما لا يحل للك النظر إليه؟

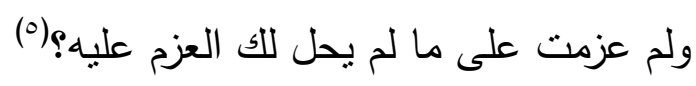

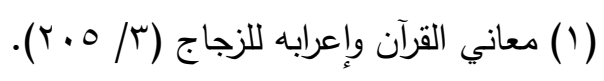

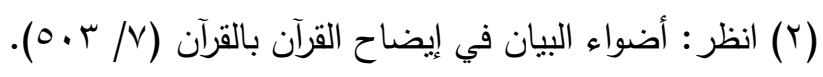

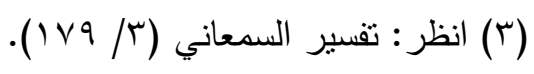

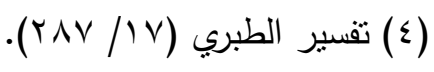

(0) انظر : أضواء البيان في إيضاح القرآن بالقرآن (r/ 100). 
ويحتمل السؤال أيضا أن يكون بمعنى المحاسبة بتتبع الأعمال وتوقيع الجزاء

المناسب عليها.

قال ابن كثثر: (ثم يسألكم يوم القيامة عن جميع أعمالكم، فيجازيكم عليها

على الفتيل والنقير والقطمير) (')

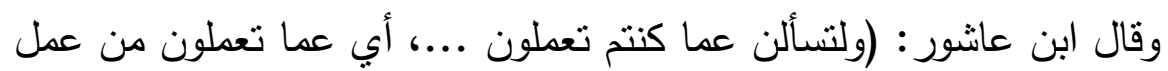

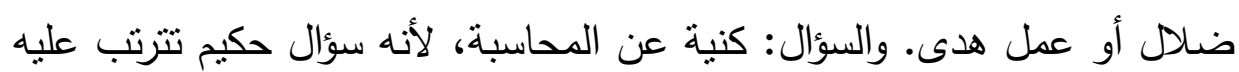

الإنارة وليس سؤال استطلاع) (؟).

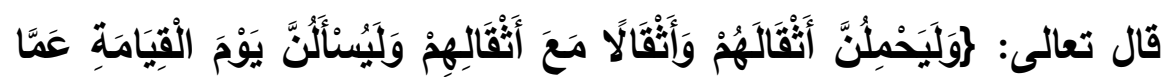

كَانُوا يَفْتَرُونَ

تتعرض الآية الكريمة للكفار ممن دعا إلى كفره وادعى أنه لو كان على خطأ

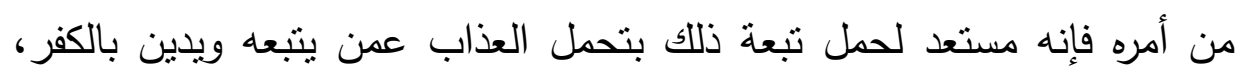

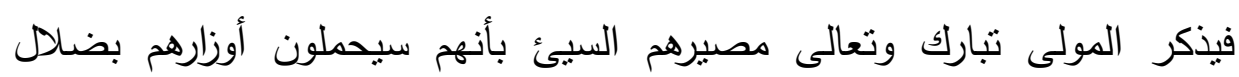

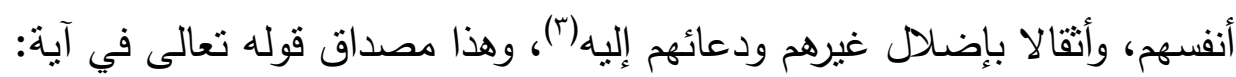

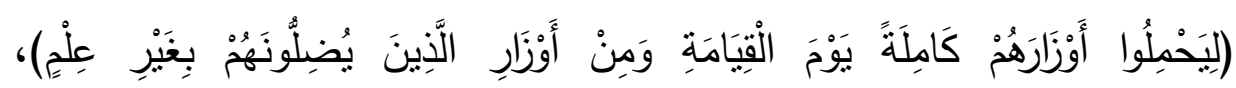

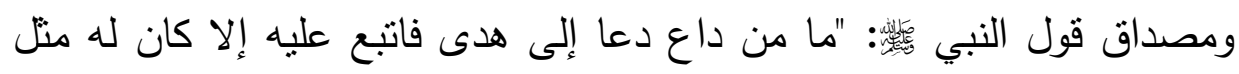

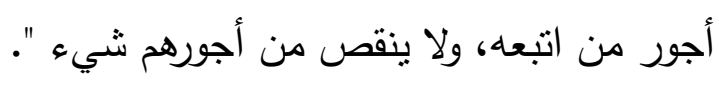

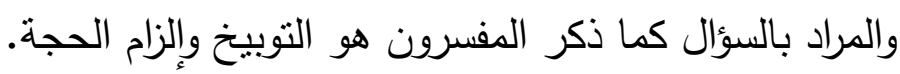

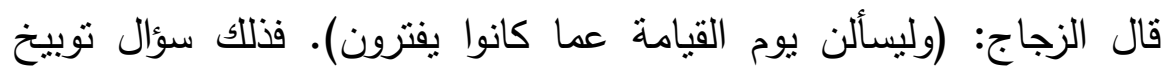

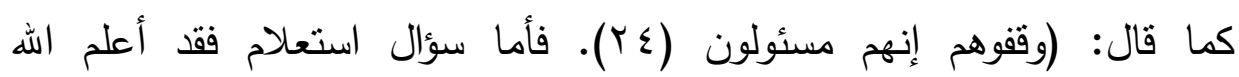

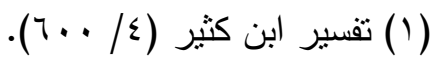

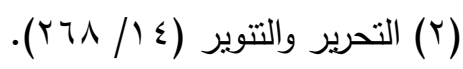

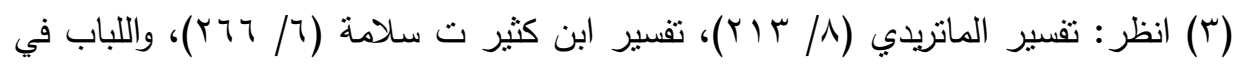

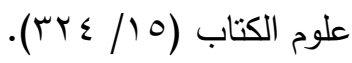




\section{د. • فه صالح الخنه}

- عز وجل - أنه لا يسأل سؤال استعلام في قوله: (فيومئذ لا يسأل عن ذنبه

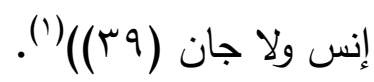

وقال ابن فورك: (يسألون سؤال توبيخ، وهو نظير سؤال تعجيز في النظر؛

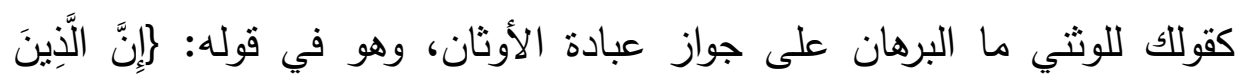

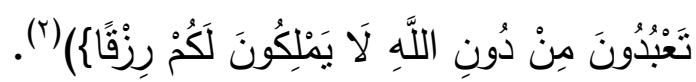

فيكون معنى السؤال حينئذ أن اله تعالى يسألهم الحجة على اتخاذهم الأصنام

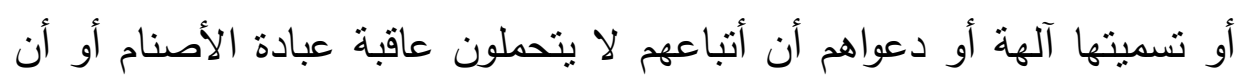
الله أمرهم بعبادتها (r)، وفي هذا السؤال توبيخ لهم إذ لا حجة لهم على ذلك لك بل فيه إلزام لهم بالحجة.

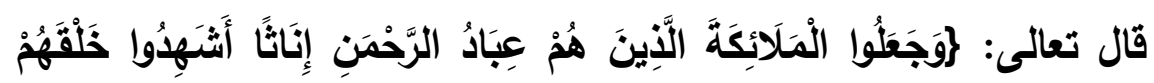

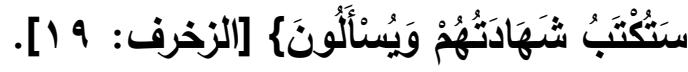

تتعرض هذه الآية لدعوى الكفار أن الملائكة إناث وأنهم بنات اله تعالى، وتذكر وعيد الله لهم في الآخرة بأنه سيحصي هذه الثهادة في كتاب وأنه سيسألهم عنها في الآخرة، ويطلب منهم الاليل على دعواهم وهذا على وجه السخرية والتقريع، إذ الله تعالى أعلم أنه ليس لهم بذللك من علم، وقد قال: روما لهم به من علم\{ أي: ليس لهم علم صحيح يصدق ما قالوه، بل هو كذب وزور وافتراء، وكفر شنيع، \} إن يتبعون إلا الظن وإن الظن لا يغني من الحق شيئأ، أي: لا يجدي

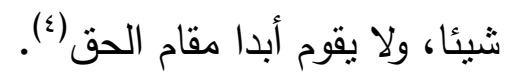

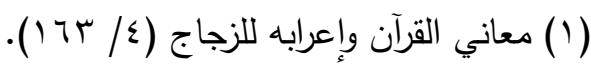

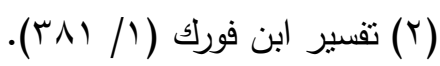

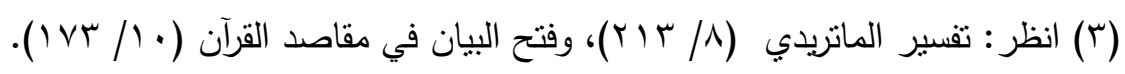

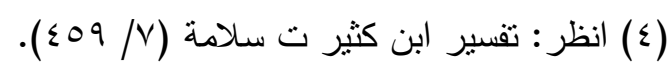


قال الطبري: (يقول تعالى ذكره: ستكتب شهادة هؤلاء القائلين: الملائكة بنات الله في الدنبا، بما شهدوا به عليهم، ويسألون عن شهادتهم تلك في الآخرة أن يأتوا ببرهان على حقيقتها، ولن يجدوا إلى ذلك سبيلا) (').

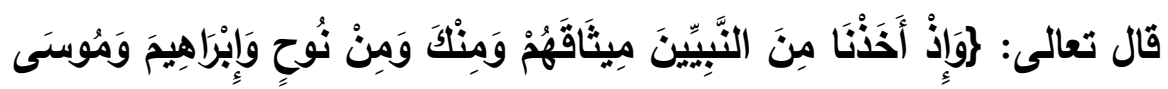

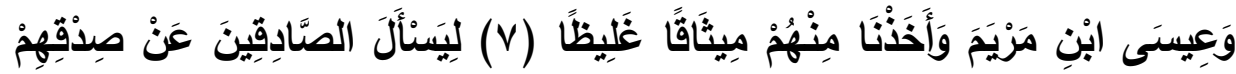

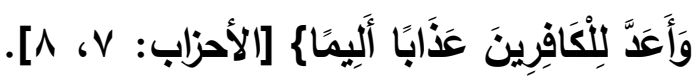

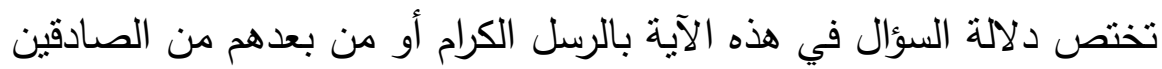

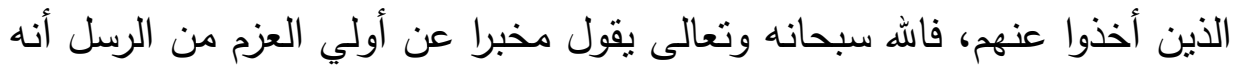

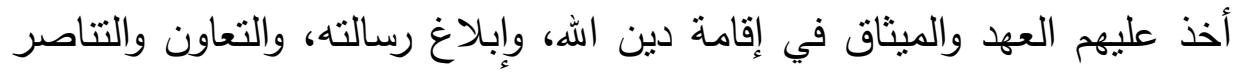

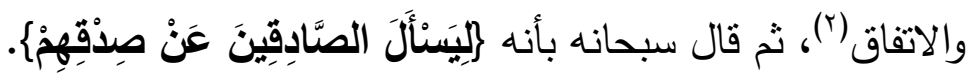

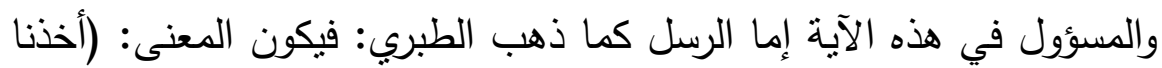

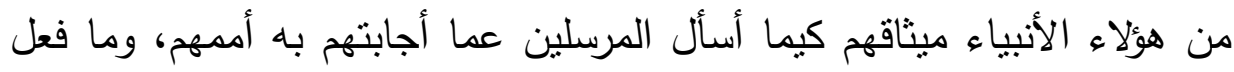
قومهم فيما أبلغوهم عن ربهم من الرسالة) (r). وقد يكون أنباعهم كما ذهب إليه ابن كثير قال: (وقوله: (ليسأل الصادقين

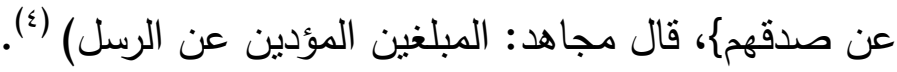
قال الزمخشري: (واذكر حين أخذنا من النبيين جميعا ميثاقهم بتبليغ الرسالة والدعاء إلى الدين القيم ومنك خصوصا ومن نوح وإبراهيم وموسى وعيسى، وإنما فعلنا ذللك؛ ليسأل الله يوم القيامة عند تواقف الأشهاد المؤمنين الذين صدقوا

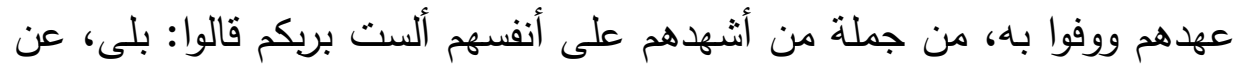

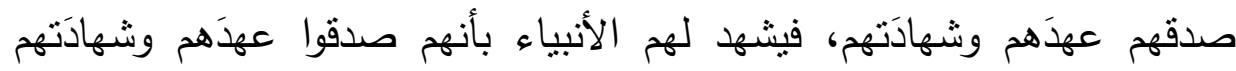

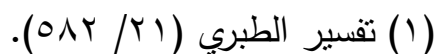

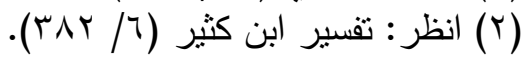

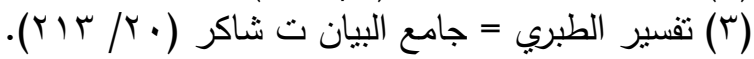

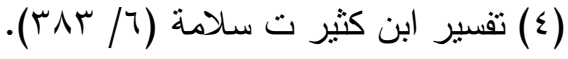

$$
\begin{aligned}
& -01 Y-
\end{aligned}
$$




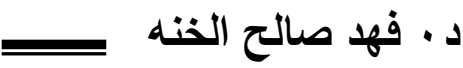

وكانوا مؤمنين. أو: ليسأل المصدقين للأنبياء عن تصديقهم؛ لأن من قال

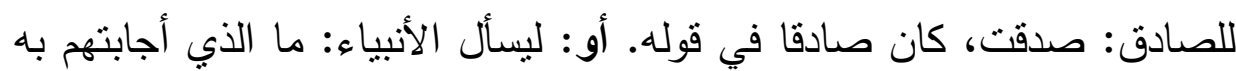

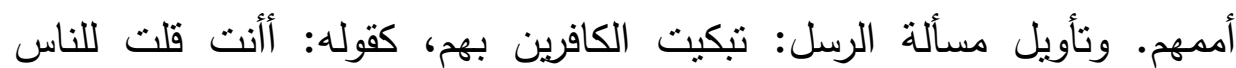
اتخذوني وأمي إلهين من دون اله) ('). ونكتة المسألة كما يذكر الثيخ الثعراوي رحمه اله أن اله تعالى بأتي بالرسل

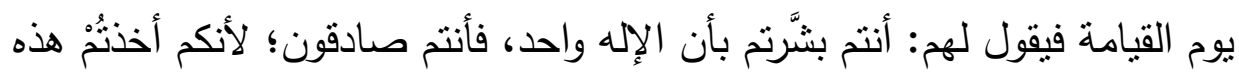

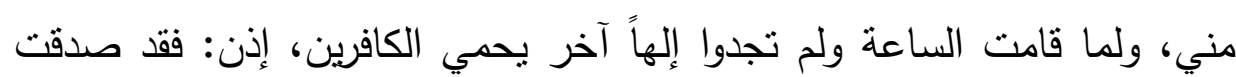
فيما أخبرت به، وصدقتم فيما بلغتم عني، حيث لم تجدوا في الآخرة إلا الإله الها

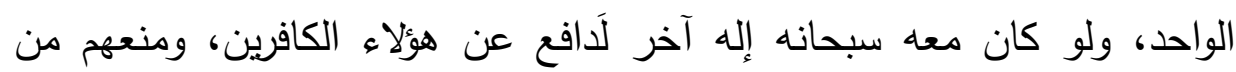

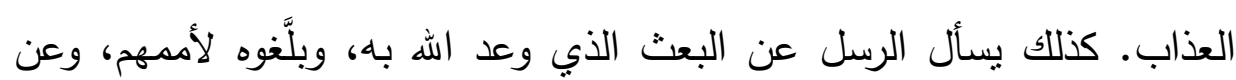

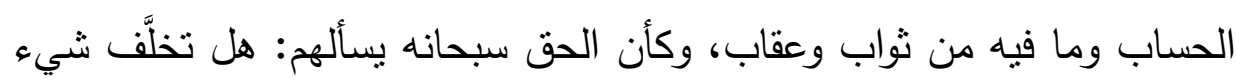

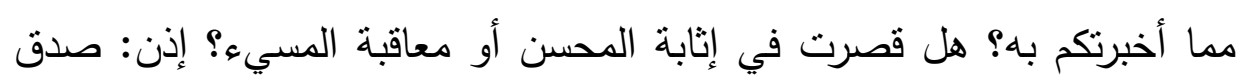

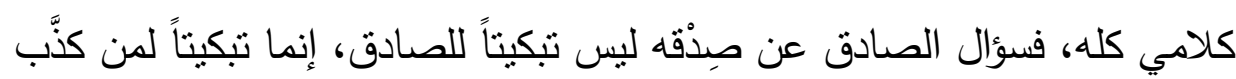

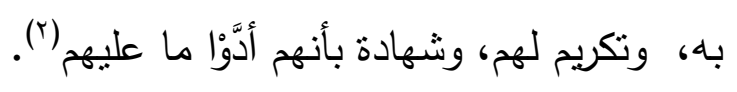

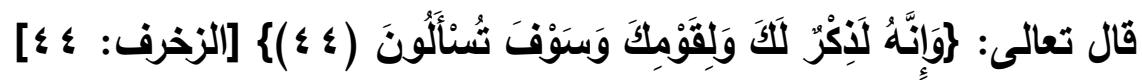

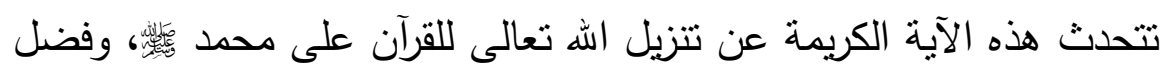

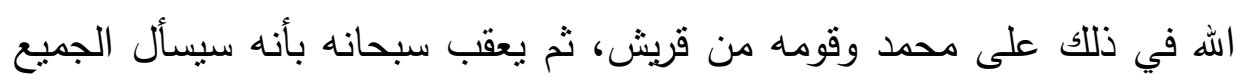

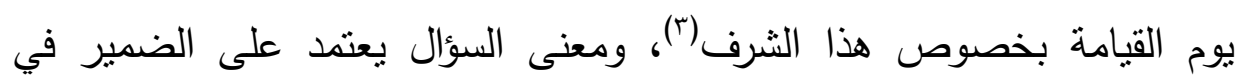
(تسألون) وفي تفسير كلمة (الذكر) وعلى المراد من قوله تعالى: (قومك).

$$
\begin{aligned}
& \text { (1) تفسير الزمخشري = الكثاف عن حقائق غوامض النتزيل (r/ ع كم). }
\end{aligned}
$$

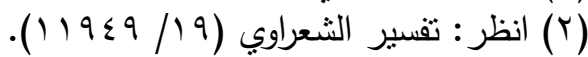

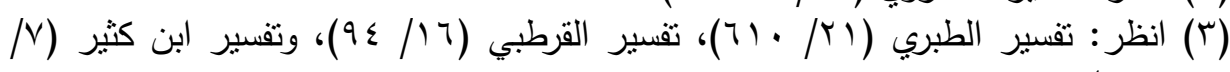




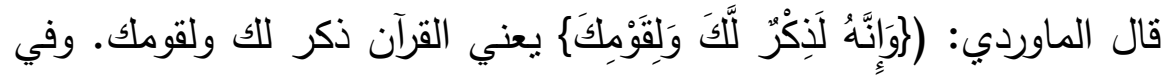

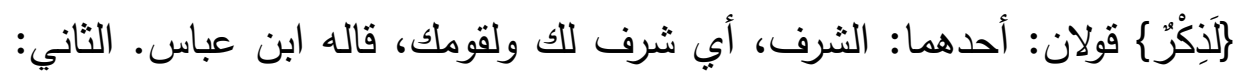
أنه لذكر للك ولقومك تذكرون به أمر الدين وتعملون باه، حكاه ابن عيسى.

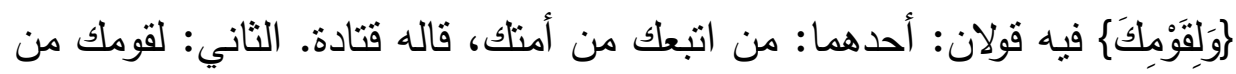

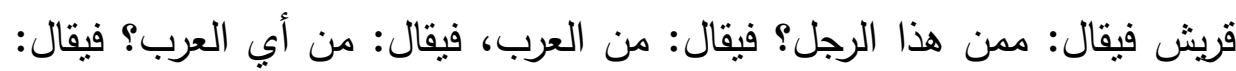

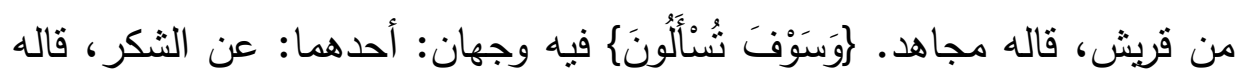

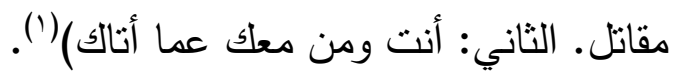
فإما أن يكون المعنى أن الله سبحانه وتعالى سيسأل قريثًا في الآخرة عن

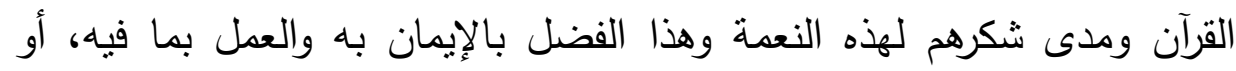
يكون السؤال عاما لجميع المسلمين يوم القيامة.

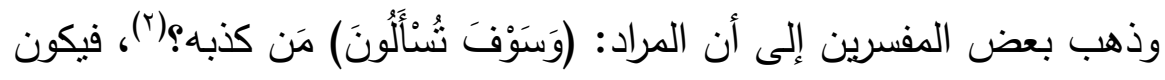

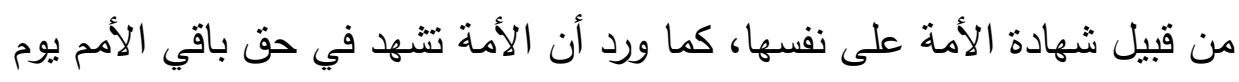

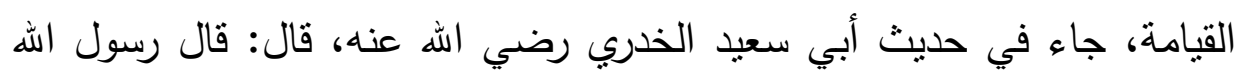

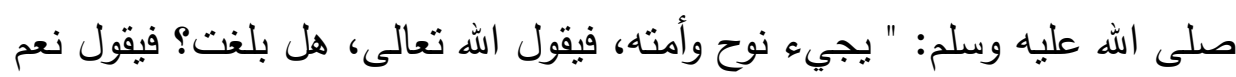

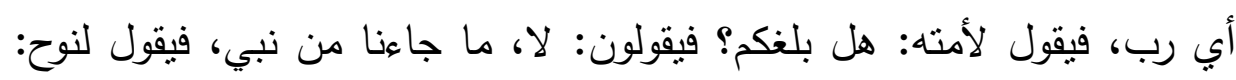

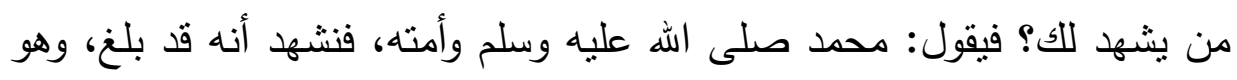
قوله جل ذكره: وكذلك جعلناكم أمة وسطا لنكونوا شهاء على الناس، والوسط

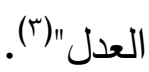

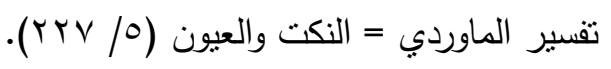

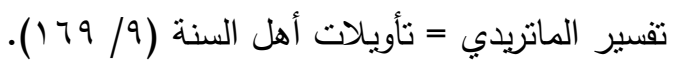

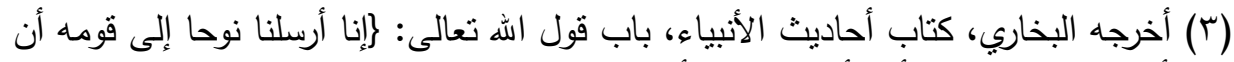

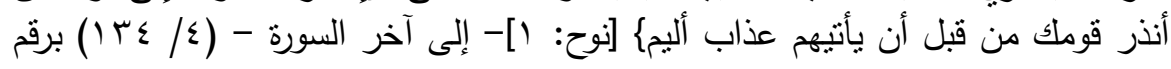




\section{د. فهز صالح الخنه ب بـ}

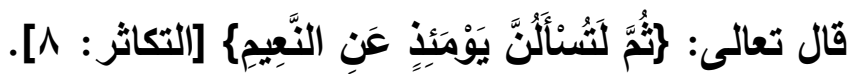

يقرر المولى تبارك وتعالى أن بيسأل العباد فيما بسألهم يوم القيامة عما أنعم

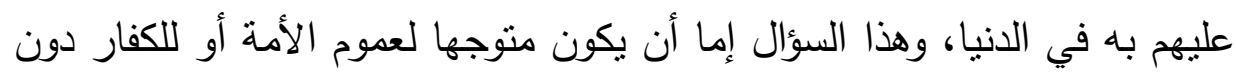

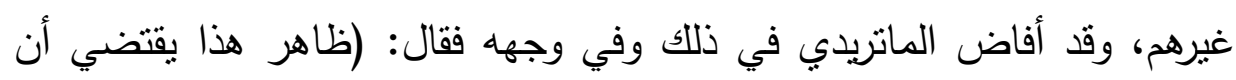

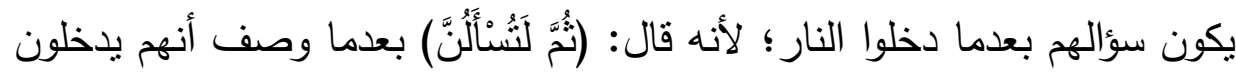

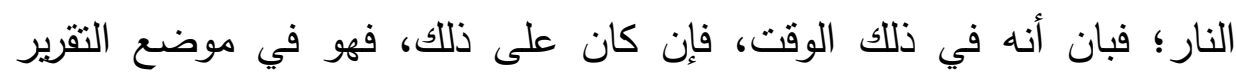

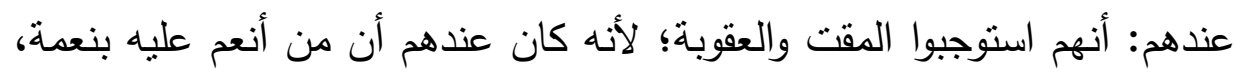

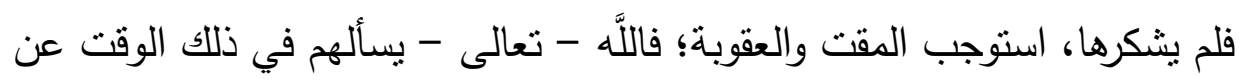
شكر ما أنعم عليهم؛ ليقرر عندهم استيجاب العقوبة.

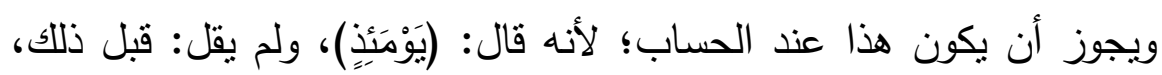

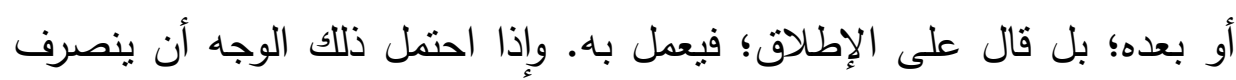

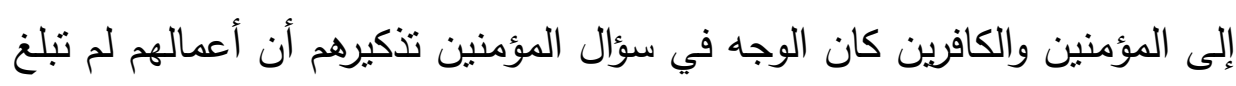

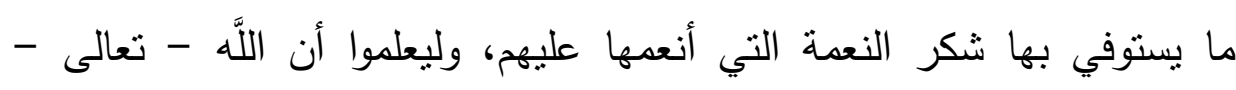

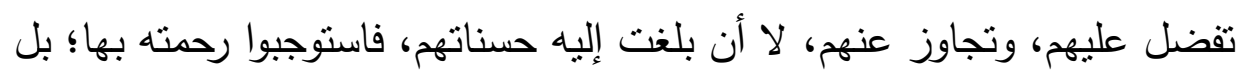

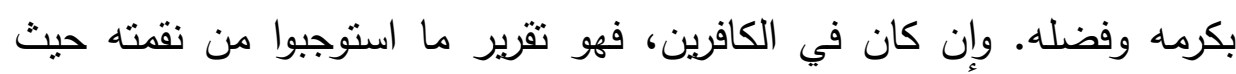
تركوا شكر نعمه)(')

وعلى هذا الثقرير فإذا كان السؤال موجها لخصوص الكافرين، فإنهم يسألون

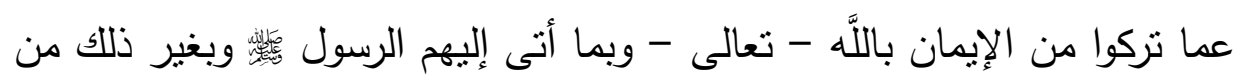

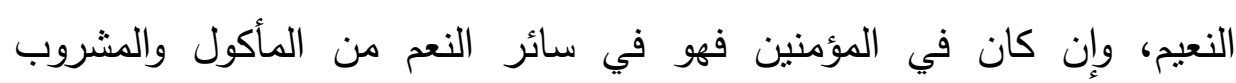
والملبوس ونحوها (؟). وبنحو ذللك فسر الماوردي الآية فقال: (وهذا السؤال يعم المؤمن والكافر ، إلا

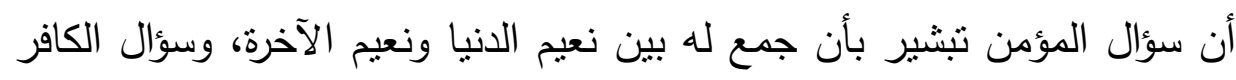


تقريع؛ لأنه قابل نعيم الدنيا بالكفر والمعصية، ويحتمل أن يكون ذلك تذكيراً بما

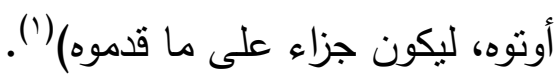

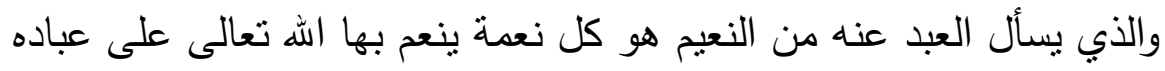

$$
\text { من ملبوس ومأكول ومشروب ومرتفق به (؟). }
$$

يقول الطبري: (والصواب من القول في ذلك: أن يقال: إن اله أخبر أنه سائل

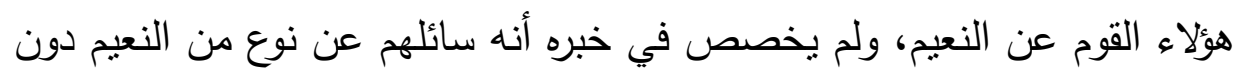

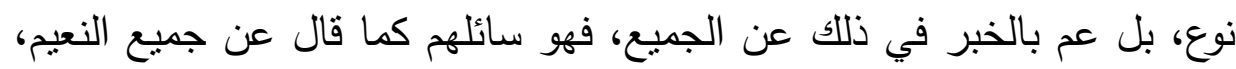
لا عن بعض دون بعض) (َ).

فيسأل العباد يوم القيامة عن هذا النعيم: ماذا عملت فيه؟ ومن أين وصلت لهابت

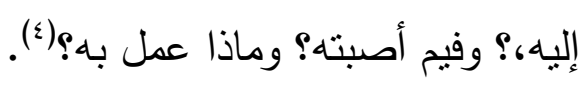

عن أبي برزة الأسلمي، قال: قال رسول الله صلى الله عليه وسلم: الا تزول

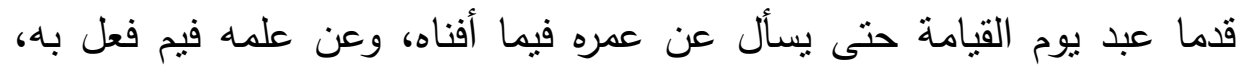

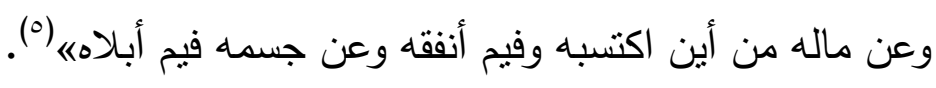

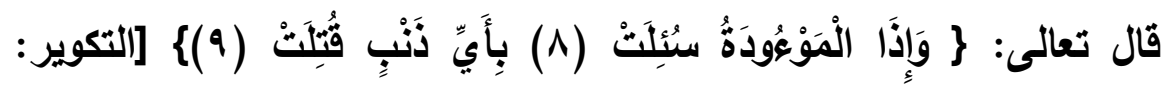

$$
\text { . }[9 \text { ، } 1
$$

يتوجه المولى تبارك وتعالى بالسؤال للموؤدوة وهي الطفلة التي دفنت حية في

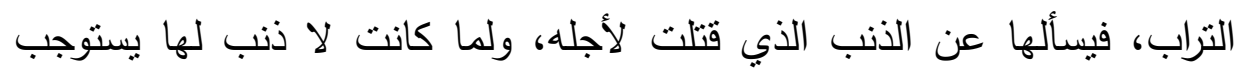

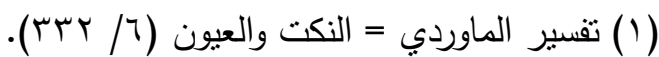

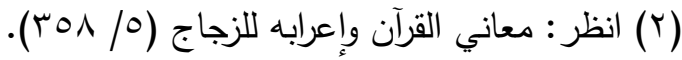

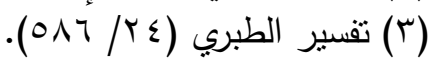

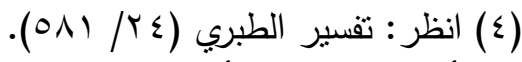

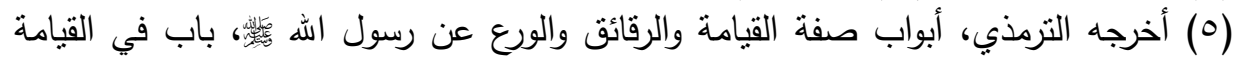

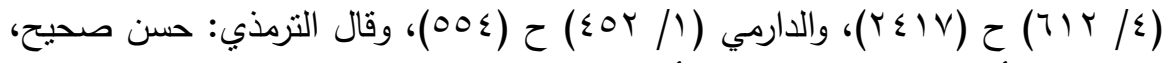

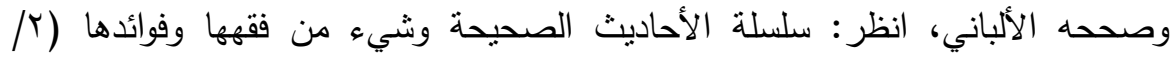




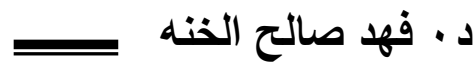

ذللك، والظاهر أن غاية السؤال "إظهار كمال الغيظ على قاتلها حتى كأنه لا يستحق أن يخاطب ويسأل عن ذلك، وفيه تبكيت لقاتلها وتوبيخ له شديد بصرف الخطاب كقوله (أنت قلت للناس) وهذه الطريقة أفظع في ظهور جناية القاتل

وإلزام الحجة عليه"(') - (ل)

قال الزمخشري: (فإن قلت: فما معنى سؤال الموؤدة عن ذنبها الذي قتلت

به، وهلا سئل الوائد عن موجب قتله لها؟ قلت: سؤالها وجوابها تبكيت لقاتلها نحو التبكيت في قوله تعالى لعيسى أنت قلت للناس ... إلى قوله ... سبحانك ما

$$
\text { يكون لي أن أقول ما ليس لي بحق) (r). }
$$

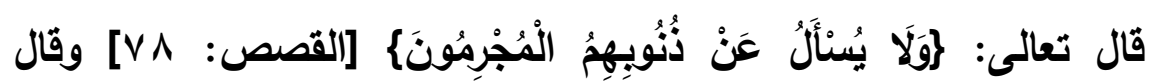

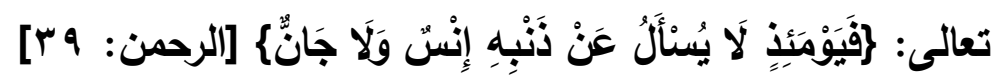

في هاتين الآيتين ينفي المولى تبارك وتعالى أنه يسأل المجرمين عن ذنوبهم،

وقد ثقرر آنفا أنه أثناء وقوع المحاسبة يسأل الله تبارك وتعالى عباده عن ذنوبهر

وعن نعمه عليهم، وعن كل ما بدر منهم في الحياة الدنيا، ولا تعارض بين هذا وذاك؛ لأن السؤال عن الذنوب المنفي في الآيات: المراد به سؤال الاستخبار والاستعلام ؛ لأنه جل وعلا محيط علمه بكل شيء، ولا ينافي نفي هذا النوع من السؤال ثثوت نوع آخر منه هو سؤال التوبيخ والتقربع؛ لأنه نوع من أنواع العذاب،

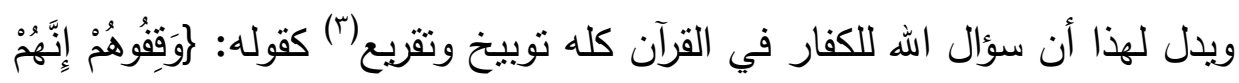

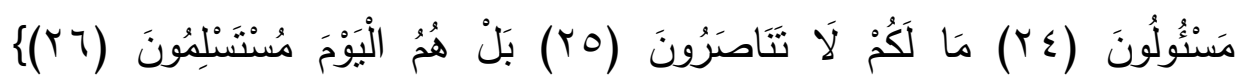

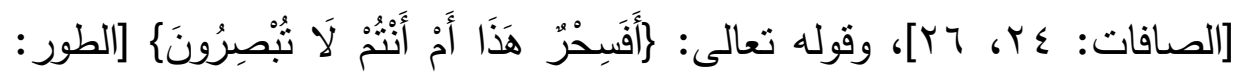

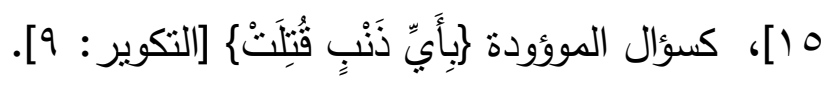

$$
\text { (1) فتح البيان في مقاصد القرآن (10/ (10 . (1). }
$$

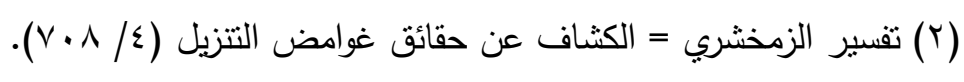

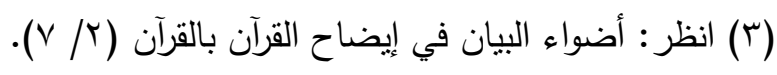


والخلاصة: أن السؤال من صور الحساب في القرآن الكريم، ومعناه على ما

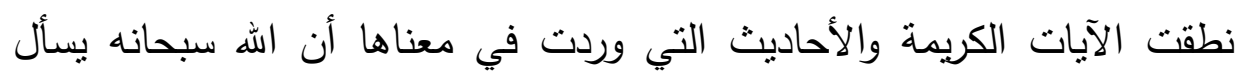

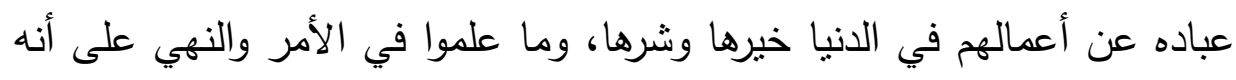

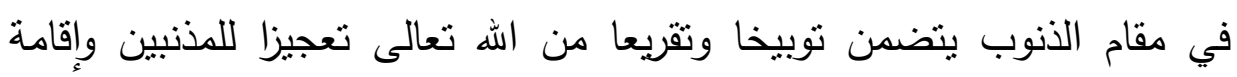

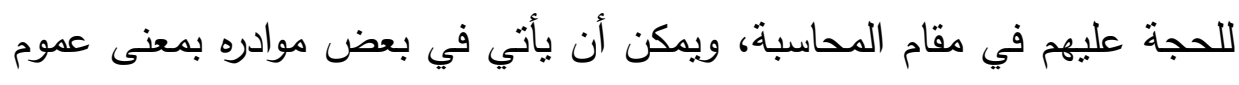
المحاسبة التي سبق عرضها فيكون كنية عن عملية المحاسبة في الآخرة بأسرها. 


\section{د. ف فه صالح الخنه}

\section{المبحث الرابع \\ الإحصاء والكتابة}

المطلب الأول: الإحصاء.

الإحصاء هو: "التحصيل بالعدد، يقال: قد أحصيت كذا، وذلك من لفظ الحصا، واستعمال ذلك فيه من حيث إنهم كانوا بعتمدونه بالعد كاعتمادنا فيه على هلى الأصابع، قال الله تعالى: وأحصى كل شيء عددا، أي: حصله وأحاط به"('). قال ابن بطال: (الإحصاء فى اللغة على وجهين: أحدهما بمعنى: الإحاطة

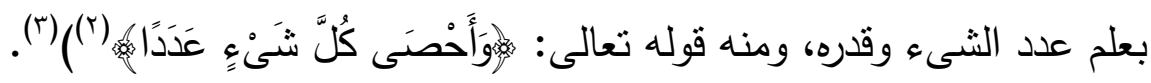
فالإحصاء هو العد، وهو من جانب الله تعالى إحاطة بعدد الثيء وقدره على

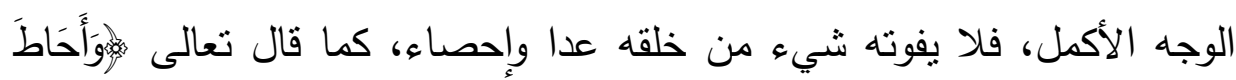

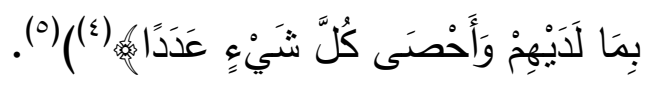
قال ابن منظور: (وفي أسماء الله تعالى: المحصي؛ هو الذي أحصى كل

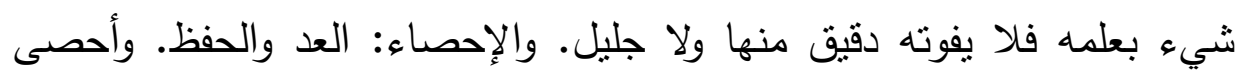
الثيء: أحاط به. وفي التنزيل: وأحصى كل شيء عددا؛ الأزهري: أب أحاط علمه سبحانه باستيفاء عدد كل شيء) (־).

(1) انظر : المفردات في غريب القرآن (ص: • ع (Y).

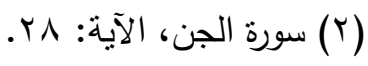

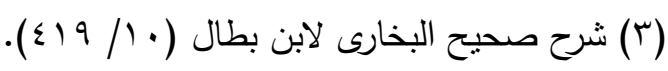

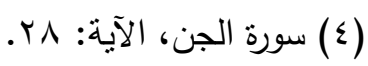

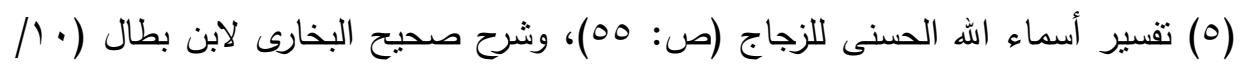


فإسناد الإحصاء إلى الله تعالى دلالته العلم التام بعدد الثيء وقدره، دق ذلك الكي

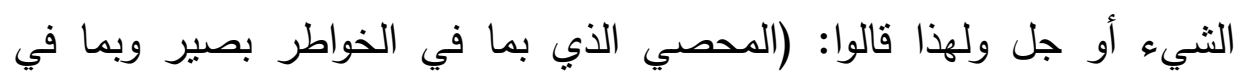
السرائر خبير) (').

ومن كان هذا حاله فإنه لا يفوته شيء من أعمال عباده إحصاء وعدا.

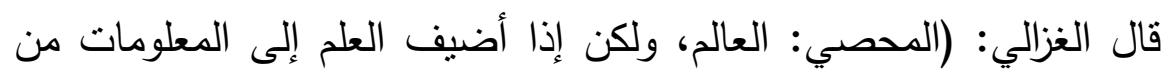

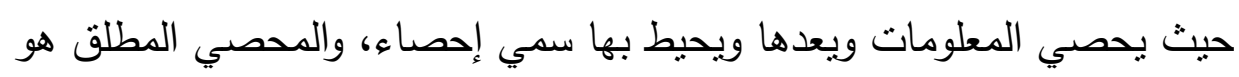

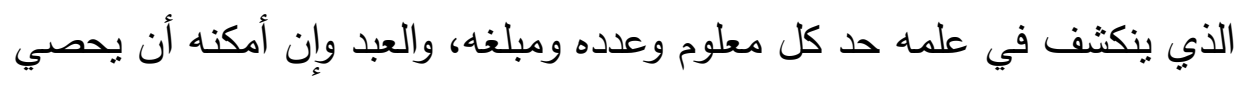

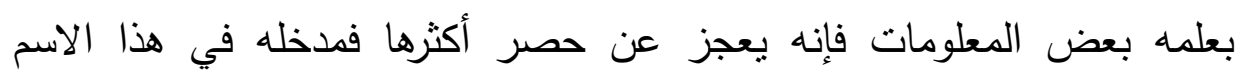
ضعيف كمدخله في أصل العلم)(؟). وقد وردت السنة النبوية بالتصريح بأن اله تعالى يحصي أعمال العباد فقال

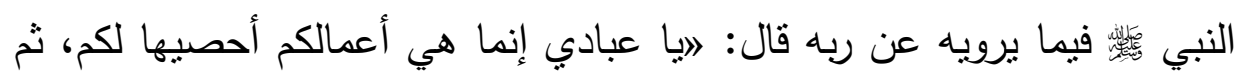
أوفيكم إياها، فمن وجد خيرا فليحمد الله، ومن وجد غير ذللك فلا يلومن إلا بلا نفساه (") آنا

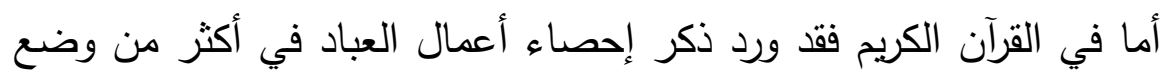

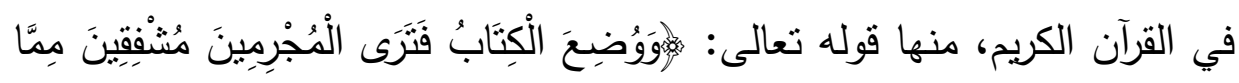

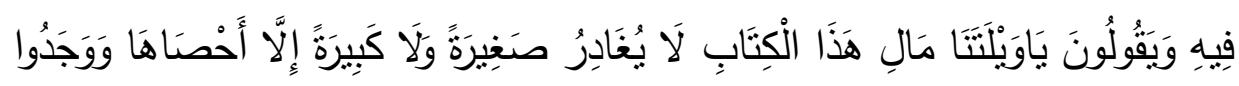

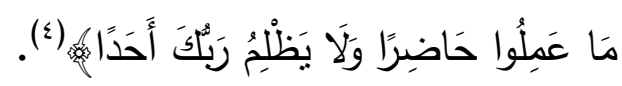

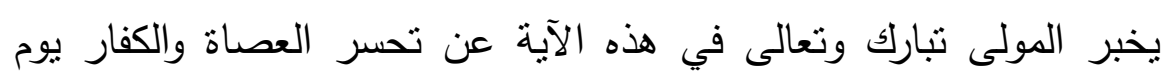
القيامة عندما تتشر الصحف وتعرض الأعمال، فيقولون: (مال هذا الكتاب لان لأل

$$
\begin{aligned}
& \text { (1) انظر : شرح أسماء الله الحسنى (ص: ع Y Y). }
\end{aligned}
$$

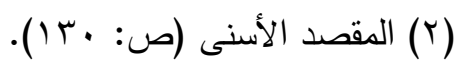

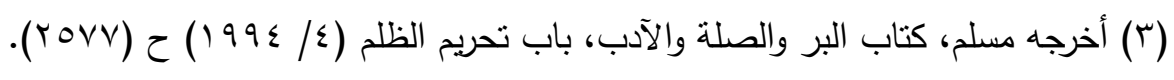

$$
\begin{aligned}
& \text { (ع) سورة الكهف، الآية: و ؟ـ. } \\
& \text {-OT.- }
\end{aligned}
$$




\section{د. ف فه صالح الخنه}

يترك أمرا صغيرا دقيقا، ولا كبيرا إلا أحصاه، أي: أنه أحاط إحاطة كاملة

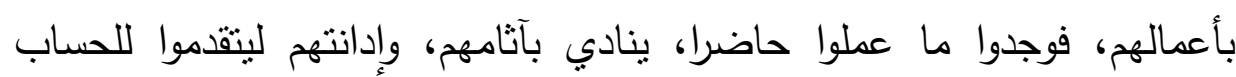
العسير الذي نهايته العقاب بالعذاب الأليم('). (ولا يظلم ربك أحدا) فلا يجازي لباني

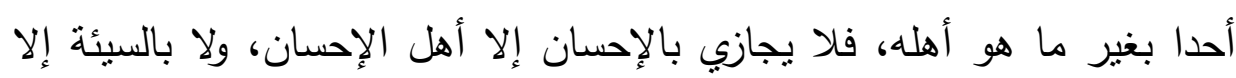
أهل السيئة، وذلك هو العدل (ץ).

قال ابن كثير: (وقوله: (وروضع الكتاب) أي: كتاب الأعمال، الذي فيه الجليل والحقير ، والفتيل والقطمير ، والصغير والكبير جفترى المجرمين مشفقين مما

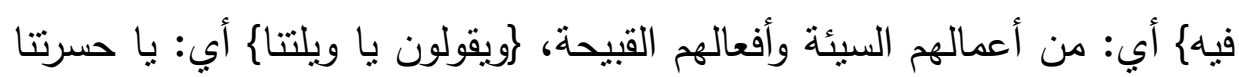
وويلنا على ما فرطنا في أعمارنا جمال هذا الكتاب لا يغادر صغيرة ولا كبيرة إلا لأل أحصاهاهُ أي: لا يترك ذنبا صغيرا ولا كبيرا ولا عملا وإن صغر كإلا أحصاها\{ أي: ضبطها، وحفظها)(").

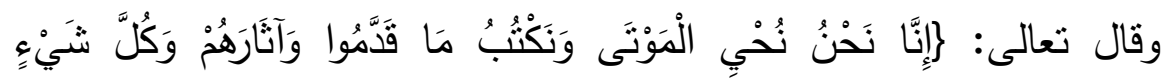

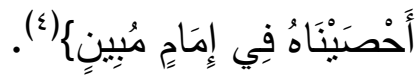

في الآية الثربفة إخبار عن أن أعمال العباد تحصى عليهم، فتكتب هذه الأعمال ليحاسب عليها العباد، ويكتب ما يترتب عليها من آثار في حياة صاحبها

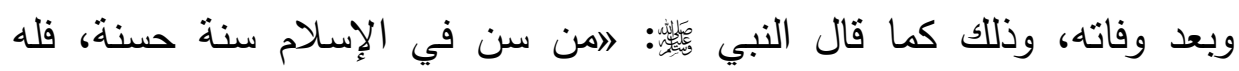
أجرها، وأجر من عمل بها بعده، من غير أن بنقص من أجورهم شيء، ومن سن

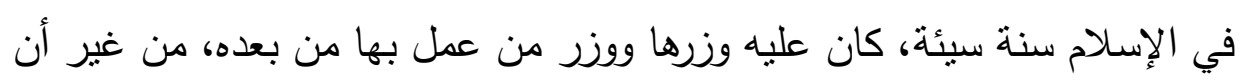




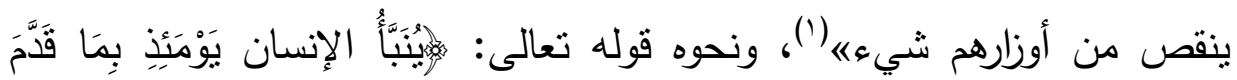

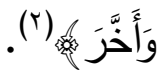

قال البيضاوي: (إنا نحن نحي الموتى الأموات بالبعث أو الجهال بالهداية، ونكتب ما قدموا ما أسلفوا من الأعمال الصالحة والطالحة. وآثارهم الحسنة كعلم علموه وحبيس وققوه، والسيئة كإثاعة باطل وتأسيس ظلم)(؟َ). وفي قوله تعالى الإمام المبين وجهان: الأول: اللوح المحفوظ وهو قول قتادة، والثاني: صحائف الأعمال، فعلى التأويل الأول "يكون ذلك بيانا لكون ما قدموا وآثارهم أمرا مكتوبا عليهم لا يبدل، فإن القلم جف بما هو كائن فلما قال: نكتب ما قدموا بين أن قبل ذلك كتابة أخرى، فإن الله كتب عليهم أنهم سيفعلون كذا وكذا، ثم إذا فعلوه كتب عليهم أنهم فعلوه"(£).

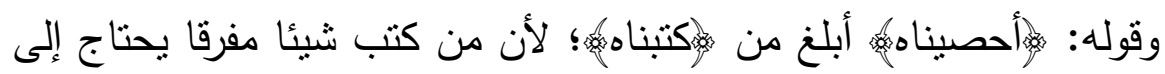

$$
\text { جمع عدده فقال: هو محصى فيه('). }
$$

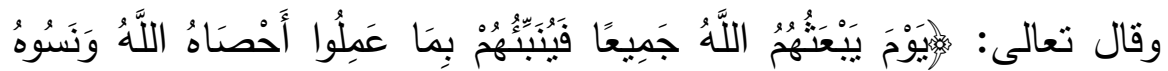

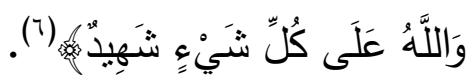

هذه الآية توعد للكافرين بالعذاب في الآخرة الذي يتتوع بين العذاب بالنار والافتضاح على رؤوس الأشهاد، فهو سبحانه سيبعث الكافرين يوم القيامة، فينبئهم

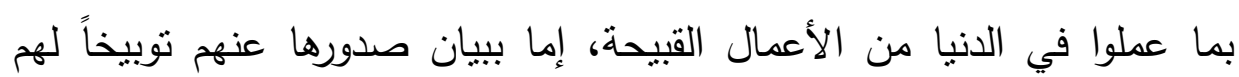

(1) أخرجه مسلم، كتاب الزكاة، باب الحث على الصدقة ولو بشق تمرة، أو كلمة طيبة وأنها

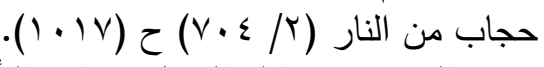

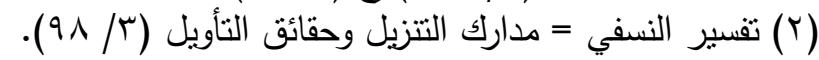

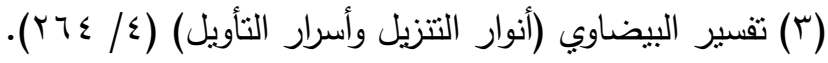

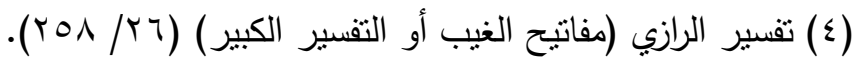

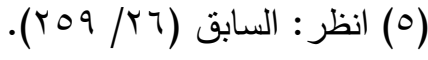

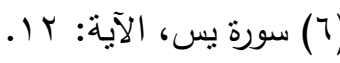




\section{د · فهز صالح الخنه}

وتكميلًً للحجة عليهم أو بتصويرها في صورة قبيحة هائلة على رؤوس الأشهاد.

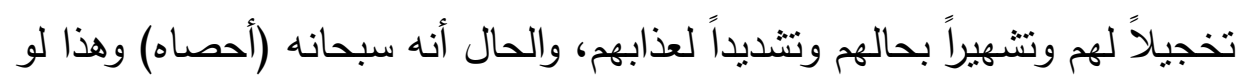
قيل: كيف ينبئهم بذلك مع كثرته واختلاف أنواعه؟ فقيل: أحصاه الله جميعاً، ولم يفته منه شيء وإن كانوا قد (نسوه) ولم يحفظوه (والله على كل شيء شهيد) أي لا يخفى عليه شيء من الأشياء، بل هو مطلع وناظر (').

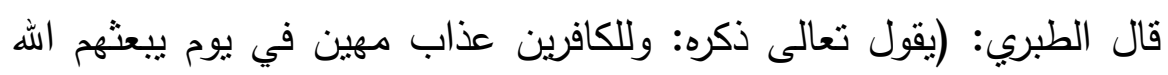
جميعا، وذلك (يوم يبعثهم الله جميعا) من قبورهم لموقف القيامة، (فينبئهم) الله (بما عملوا أحصاه الله ونسوه). يقول تعالى ذكره: أحصى الله ما عملوا، فعده عليهم، وأثبته وحفظه، ونسيه عاملوه. (والله على كل شيء شهيد) يقول: (والله) جل ثناؤه (على كل شيء) عملوه، وغير ذلك من أمر خلقه (شهيد) يعني: شاهد

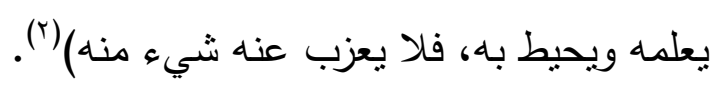

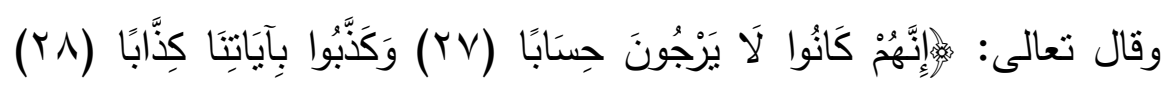

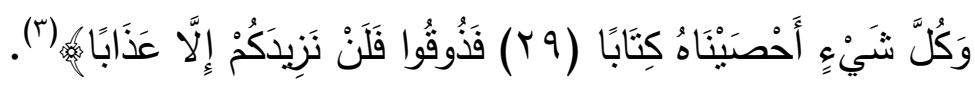

في هذه الآية يخبر المولى تبارك وتعالى عن فئة من عباده أنكرت الحساب وكذبت بآيات الله تعالى: أنه عالم بجميع ما فعله عباده، وعالم بجهات تلاك الأفعال وأحوالها واعتباراتها التي لأجلها يحصل استحقاق الثواب والعقاب، وأنه سوف بعذبهم على قبائح أعمالهم في الآخرة، ويقول لهم: ذوقوا، والأمر أمر إهانة وتحقير ، كما أنه سبحانه سوف يزبد في عذابهم ومن الزيادة: أنه كلما نضجت جلودهم بدلهم الله جلوداً غيرها، وكلما خبت النار زادهم الله سعيراً(๕).

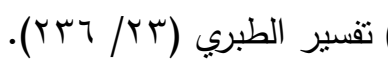

$$
\begin{aligned}
& \text { سورة النبأ، الآية: V V - . r. }
\end{aligned}
$$

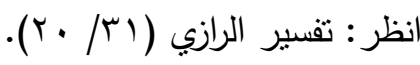




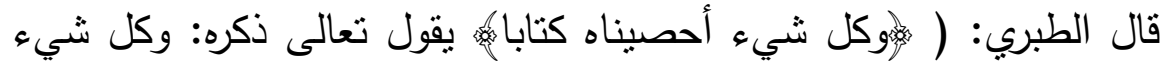
أحصيناه فكتبناه كتابا، كتبنا عدده ومبلغه وقدره، فلا يعزب عنا علم شيء مناه،

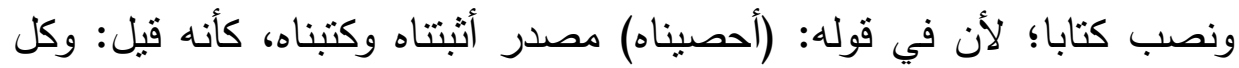

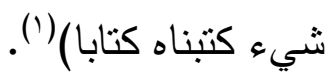

والإحصاء المذكور قد براد به ما كتب في اللوح المحفوظ أو ما كتبه الحفظة

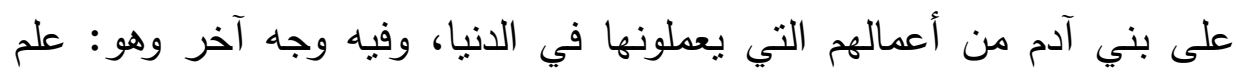

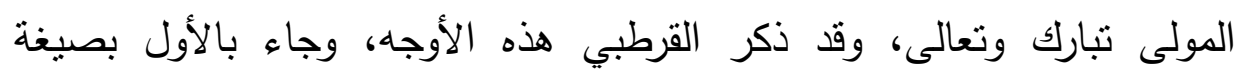

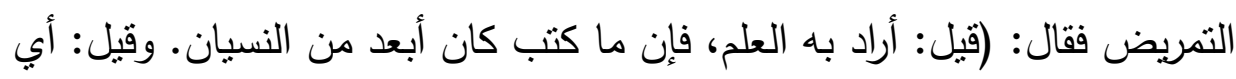

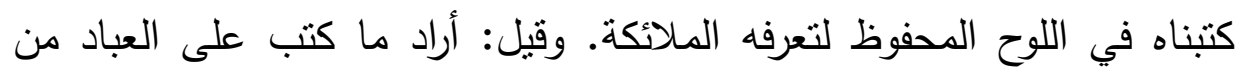

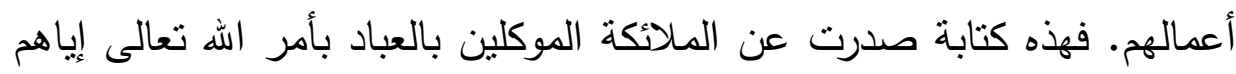

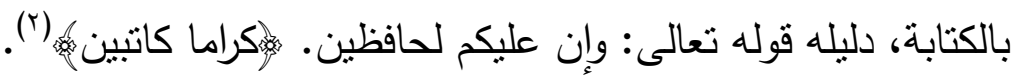

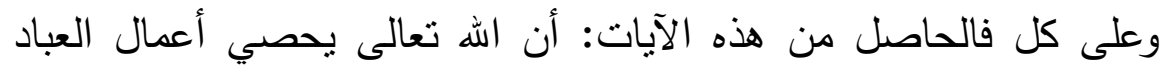

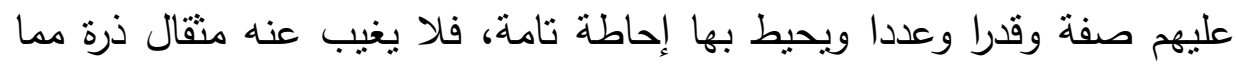
عملوه، ثم يجازيهر عليها كما سبق بيانه في مبحث الحساب. المطلب الثاني: الكتابة. جاءت كتابة الأعمال في آيات القرآن الكريم للالالة على تقييد كل ما يصدر

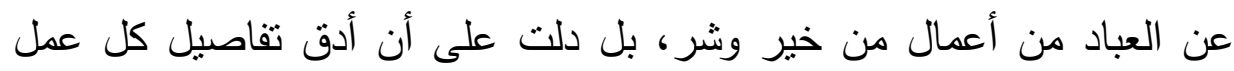

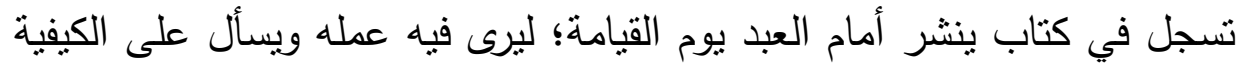

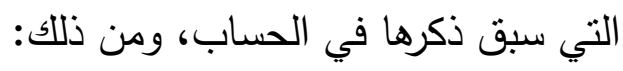

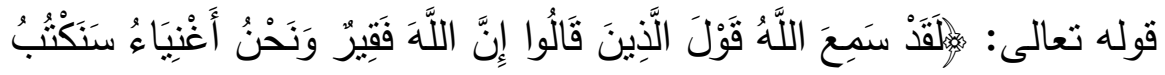

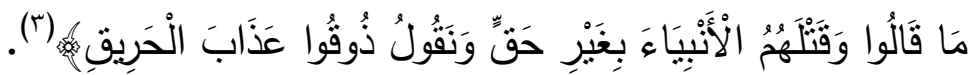




\section{د. ف فهز صالح الخنه}

قال السدي: قالها فنحاص اليهودي من بني مرثذ، لقيه أبو بكر فكلمه، فقال له: يا فنحاص، اتق الهه وآمن وصدق، وأقرض اله قرضا حسنا! فقال فنحاص: يا أبا بكر، تزعم أن ربنا فقير يستقرضنا أموالنا! وما يستقرض إلا الفقير من الغني!

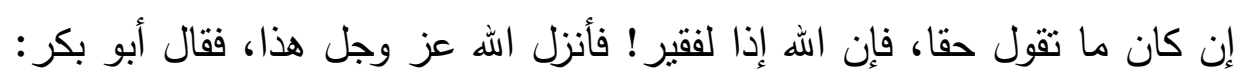
فلولا هدنة كانت بين النبي صلى الله عليه وسلم وبين بني مرثذ لقتلته(').

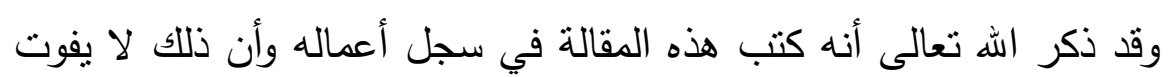

عليه وأنه سيحاسبه على ذلك يوم القيامة(؟). قال السمرقندي: (يكتب عليهم الكرام الكانبون وبؤاخذون به في الآخرة، (وقتله)، أي: ونكتب قتلهم الأنبياء بغير حق يعني: بلا جرم ونقول: ذوقوا عذاب الحريق، أي: تقول لهم خزنة جهنم في الآخرة ذلك)(").

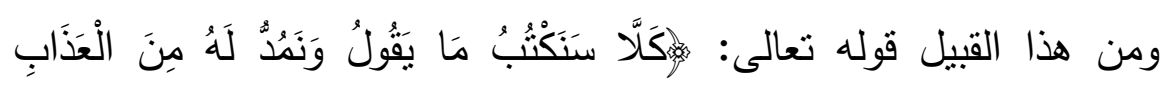

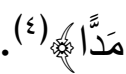

وقد جاء في كليهما بالتسويف، مع أن الحفظة كتبوه عليه بمجرد صدوره منه

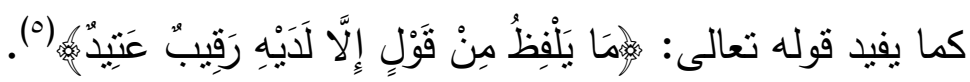
وقد أجاب الزمخثري عن هذا التساؤل فقال: (قلت: فيه وجهان، أحدهما: سنظهر لله ونعلمه أنا كتبنا قوله ... أى تبين وعلم بالانتساب أنى لست بابن

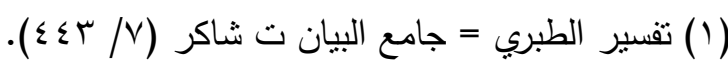

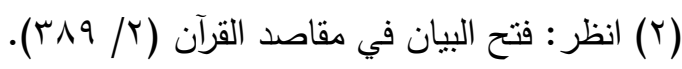

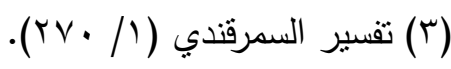

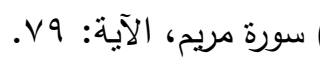

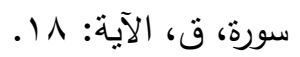


للئيمة. والثاني: أن المتوعد يقول للجاني: سوف أنتقم منأك، يعنى أنه لا يخل بالاتتصار وإن تطاول به الزمان واستأخر ، فجرد هاهنا لمعنى الوعيد) (').

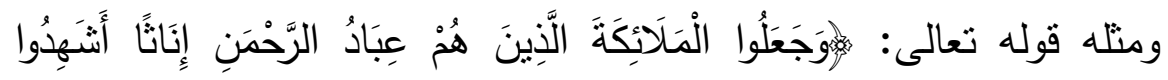

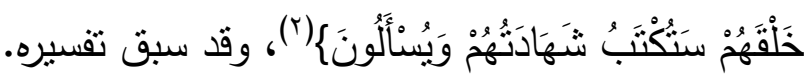

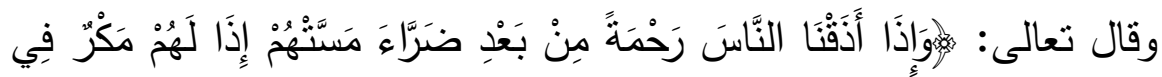

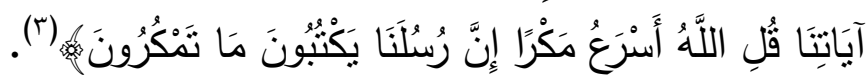
فيه بيان أن الرسل الحفظة يسجلون هذا المكر؛ ليعاقبهر عليه المولى في

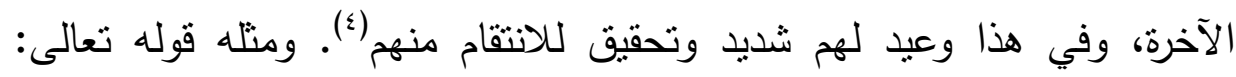

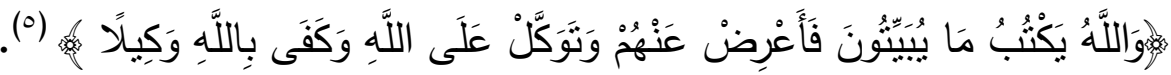

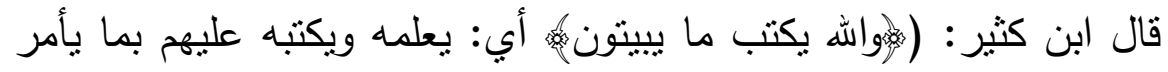
به حفظته الكانتين، الذين هم موكلون بالعباد. يعلمون ما يفعلون. والمعنى في هذا

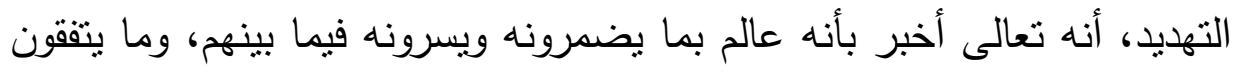

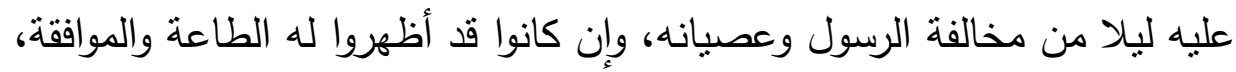

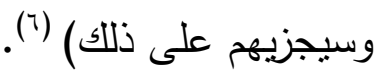

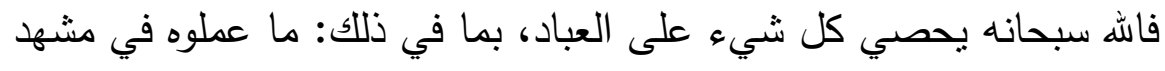

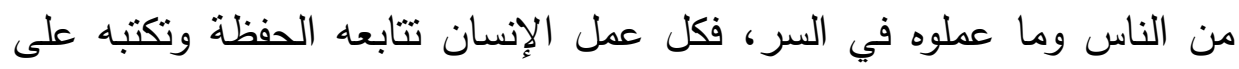

$$
\begin{aligned}
& \text { (Y) تقسير السمرقندي (T/ • (YV). } \\
& \text { (Y) سورة الزخرف، الآية: } 9 \text { (Y) }
\end{aligned}
$$

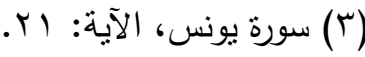

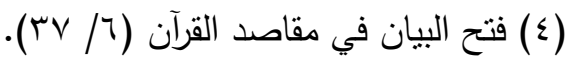

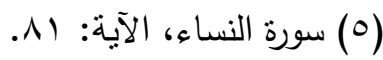

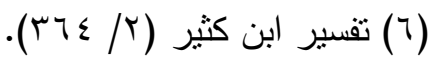




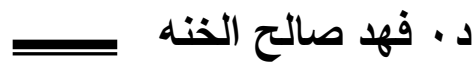

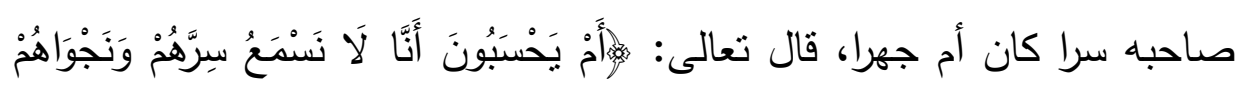

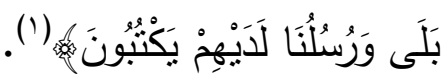
قال الطبري: (وقوله: (بلى ورسلنا لديهم يكتبون) يقول تعالى ذكره:

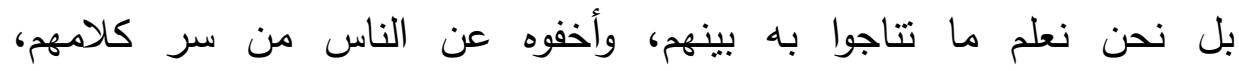

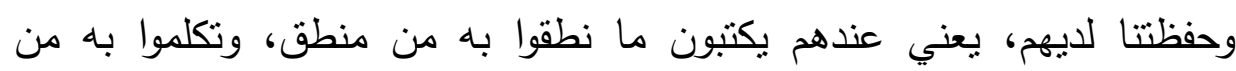

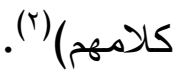
وذكر الطبرى أن هذه الآية نزلت في نفر ثلاثة تدارعوا في سماع الله تبارك

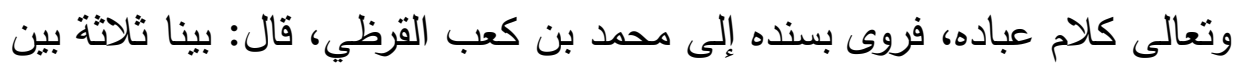

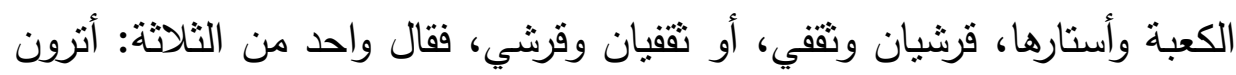

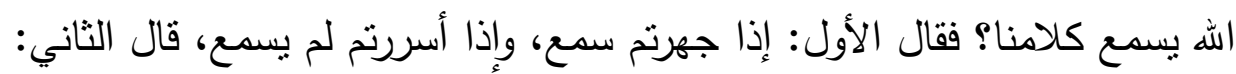

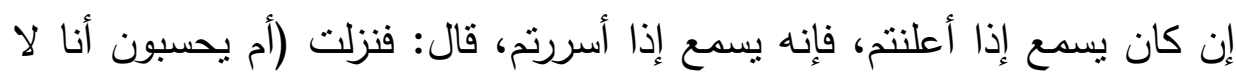

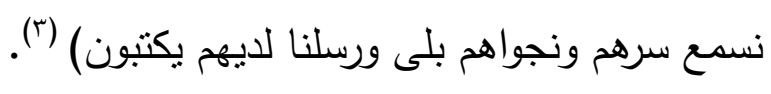

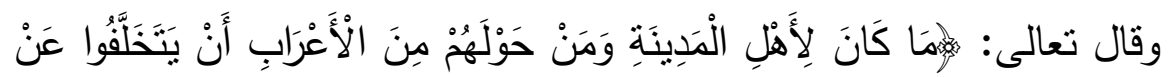

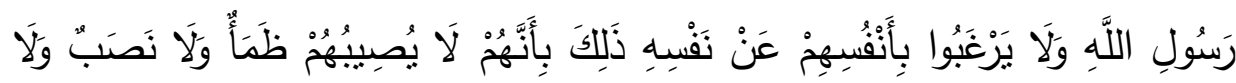

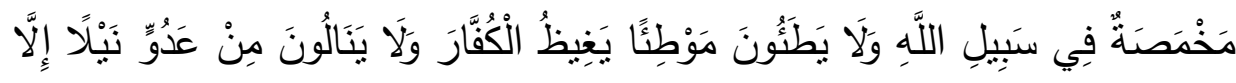

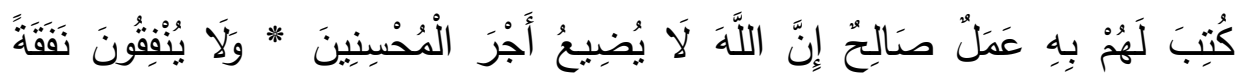

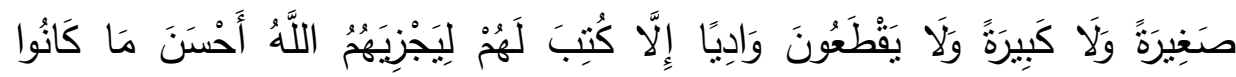

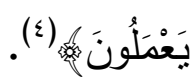

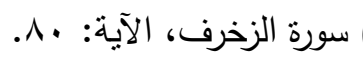

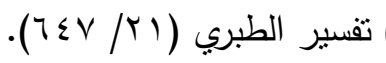

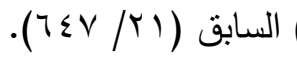

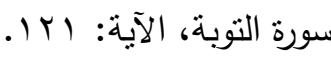


فهاتان الآيتان تصوران كيفية كتابة الأعمال وأن الطاعة الواحدة أو الدعصية

تكتب ويكتب كل ما يتعلق بها من تفاصيل (')

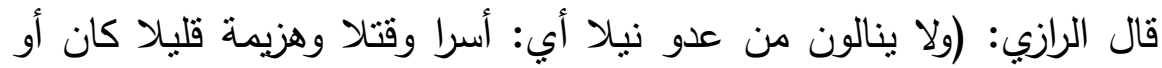

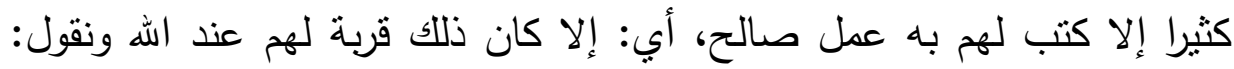
دلت هذه الآية على أن من قصد طاعة الله كان قيامه وقعوده ومشيته وحركته

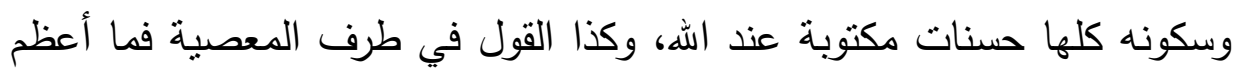

بركة الطاعة! وما أعظم شؤم المعصية!) (؟).

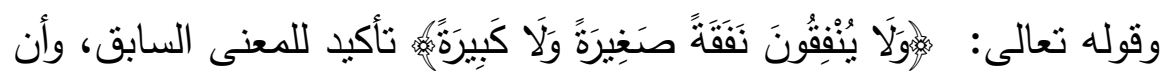

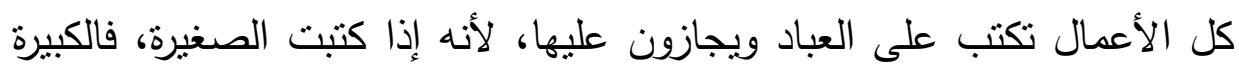

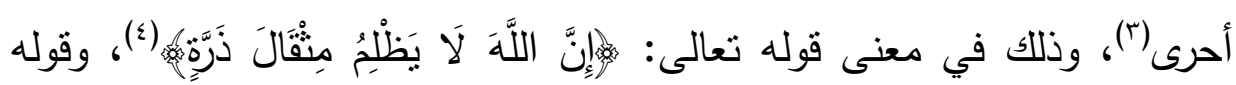

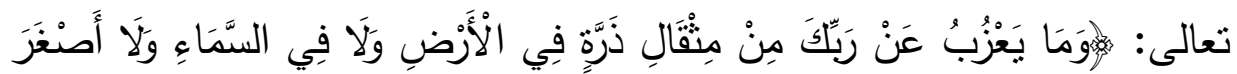

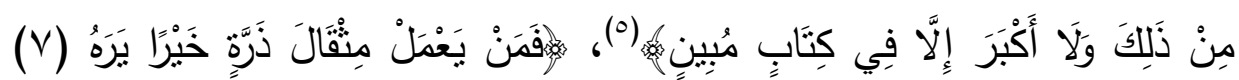

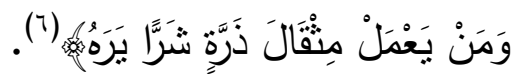

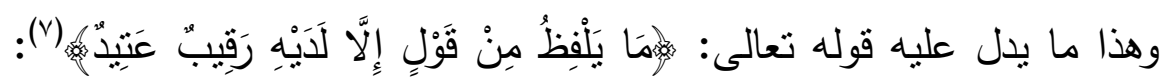

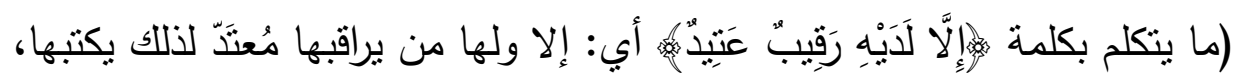

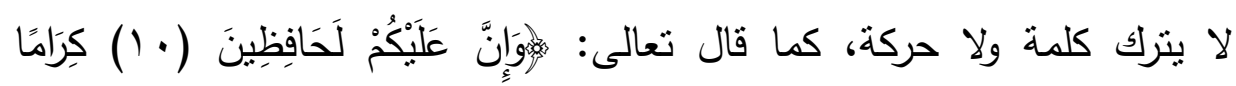

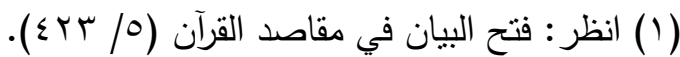

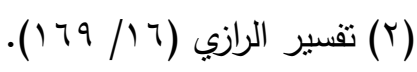

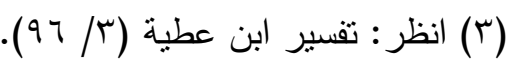

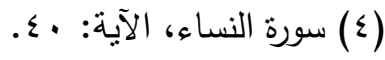

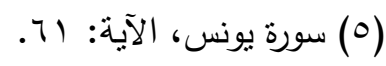

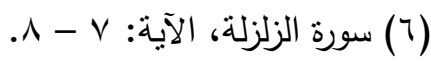

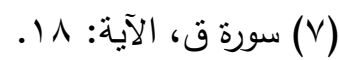




\section{د. ف فه صالح الخنه}

كَاتِِِينَ (1)، وقد اختلف العلماء: هل يكتب الملك كل شيء من الكلام؟ وهو قول

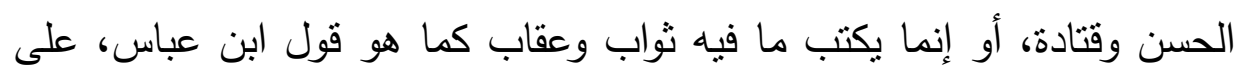

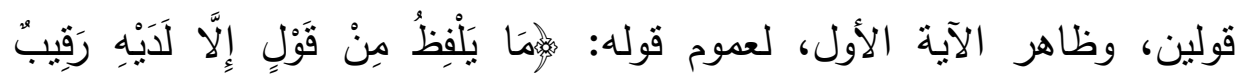

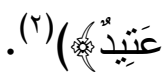

وقد وردت صفة كتابة الأعمال في حديث ابن عباس عن النبي يروي عن ربه عز وجل قال: قال: 》إن الله كتب الحسنات والسيئات ثم بين ذلك، فمن هم بحسنة فلم يعملها كتبها الله لله عنده حسنة كاملة، فإن هو هم بها فعملها كتبها الله لله عنده عثر حسنات إلى سبع مائة ضعف إلى أضعاف كثيرة، ومن هم بسيئة فلم يعملها كتبها الله له عنده حسنة كاملة، فإن هو هم بها فعملها كتبها

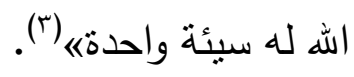
والحاصل أن كتابة الأعمال لها نفس معنى الإحصاء في المطلب الأول، فالكتابة هنا كتابة إحصاء ورصد دقيق لكل ما يصدر عن العباد، فيسجل الحفظة عليهم كل ما جاءوا به من أقوال وأفعال ثم تعرض عليهم يوم القيامة ليجازوا عليها بما يتتاسب معها، فمن عمل في الدنيا وزن ذرة من خير، يجازى على ذلك خيرا، ومن عمل في الدنيا وزن ذرة من شر يجازى على ذلك شراء().

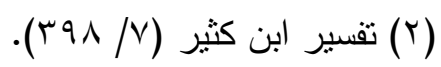

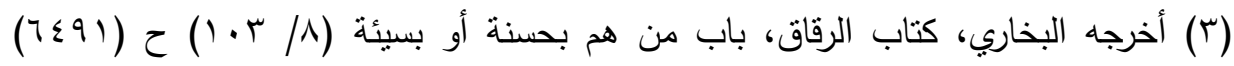
ومسلم، كتاب الإيمان، باب إذا هم العبد بحسنة كتبث، وإذا هم بسيئة لم تكتب (1/ / 1 / )

$$
\text { (1) ح }
$$

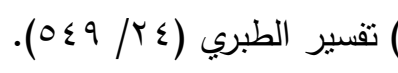




\section{المبحث الخامس}

\section{الوزن والميزان}

المطلب الأول: الوزن والميزان في اللغة.

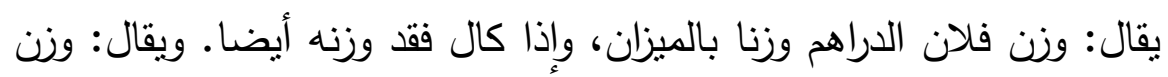

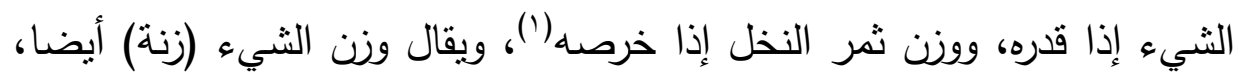

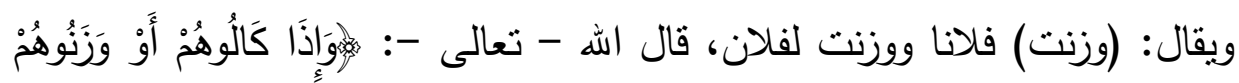

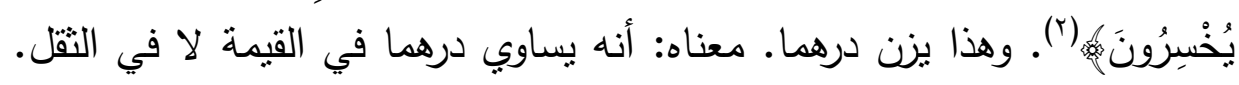

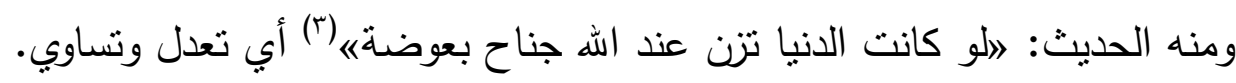

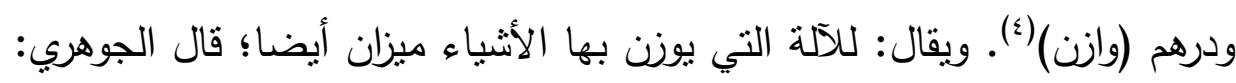

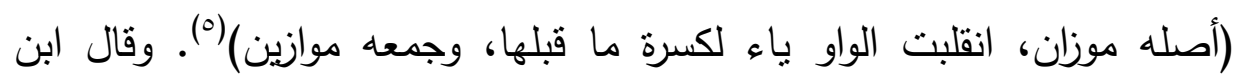

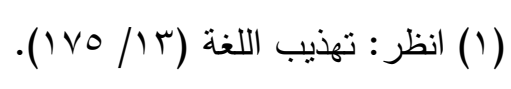

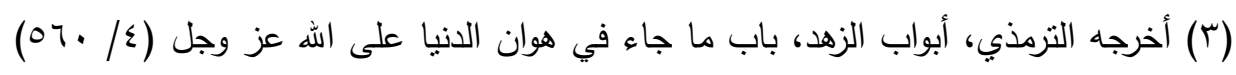

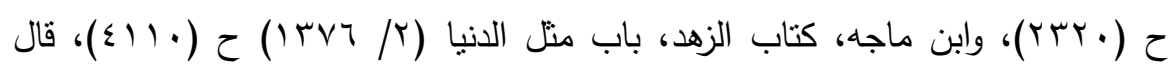

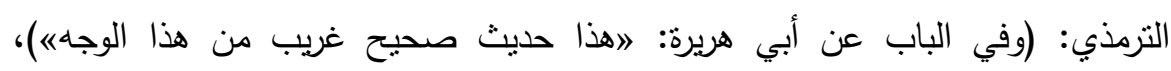

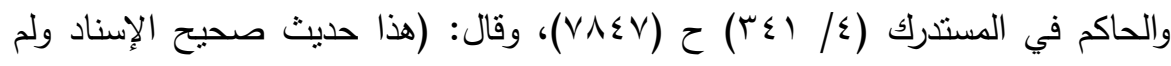

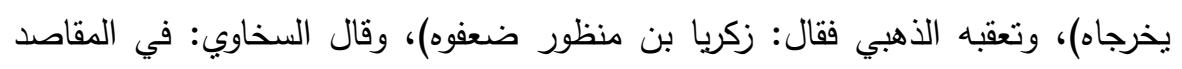

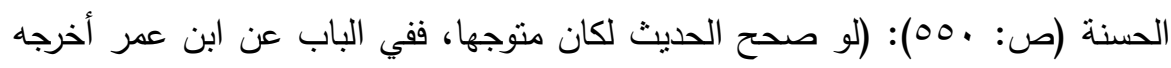

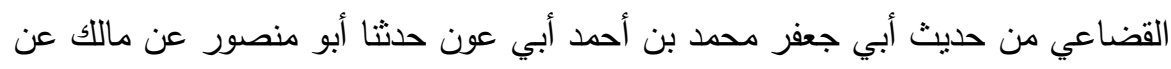

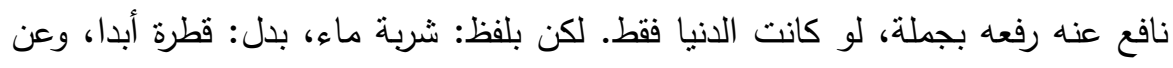
أبي هريرة أنشار إليه التزمذي).

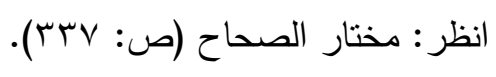

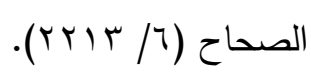




\section{د. ف فه صالح الخنه}

فارس: (وجائز أن تقول للميزان الواحد بأوزانه موازين. قال الله تعالى: ونضع الموازين القسط؛ يريد نضع الميزان القسط)('). المطلب الثاني: الوزن والميزلن في القرآن والسنة. ورد الوزن والميزان في القرآن الكريم والسنة النبوية بنفس معناهما في اللغة، فالوزن هي عملية حساب الأعمال بآلة لها كيفية يعلمها الله تعالى، وقد ورد ذلك ولك في عدد من آيات القرآن الكربم أتناولها بالدراسة فيما يلي:

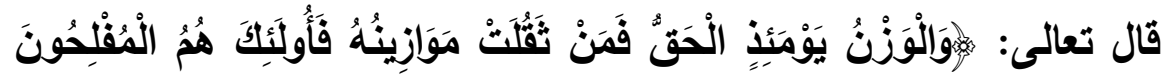

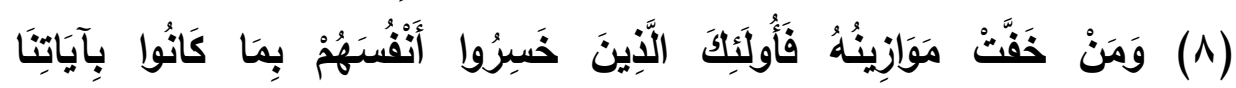
يَظظلْمُونَ (r)

اختلف أهل العلم في كيفية هذا الوزن على أقوال:

الأول: أن الذي يوزن هو صحائف أعمال العباد بالميزان وزناً حقيقياً. الثاني: أنه نفس الأعمال وإن كانت أعراضاً فإن الله يقلبها يوم القيامة أجساماً كما جاء في الخبر الصحيح "أن البقرة وآل عمران تأنيان يوم القيامة كأنهما غمامتان، أو كأنهما غيايتان، أو كأنهما فرقان من طير صواف، إن، تحاجان

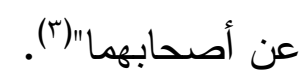

الثالث: أن الذي يوزن هو نفس الأشخاص العاملين. وقيل الوزن والميزان بمعنى العدل والقضاء وذكرهما من باب ضرب المنل

كما تقول هذا الكلام في وزن، هذا قاله مجاهد(ء).

$$
\begin{aligned}
& \text { (1) لسان العرب (T// 7؟ §). } \\
& \text { (Y) سورة الأعراف، الآيتان: \م، } 9 .
\end{aligned}
$$

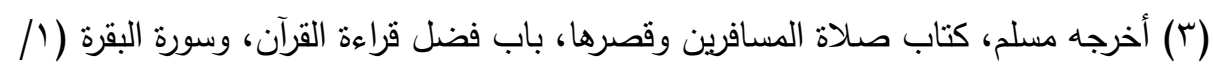

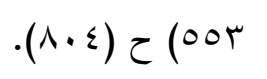

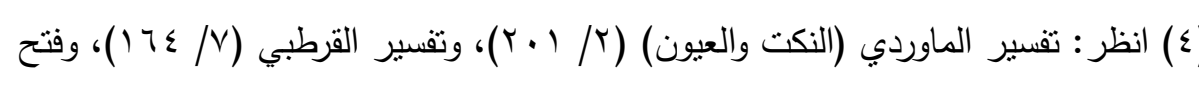

$$
\text { البيان في مقاصد القرآن (ع/ ع • (ץ). }
$$


قال الزجاج: (وهذا كله في باب اللغة - والاحتجاج سائغ، إلا أن الأولى من

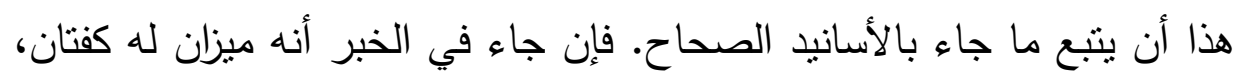

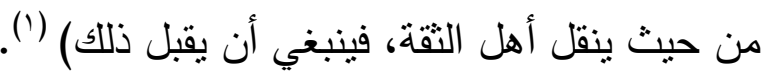

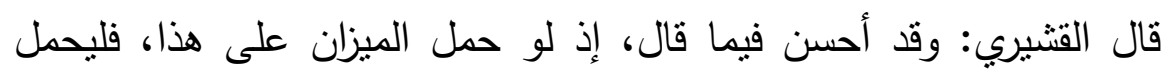

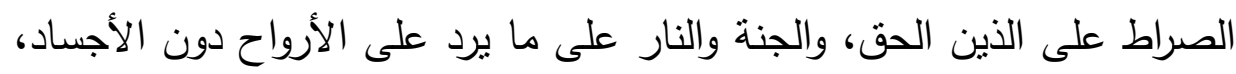

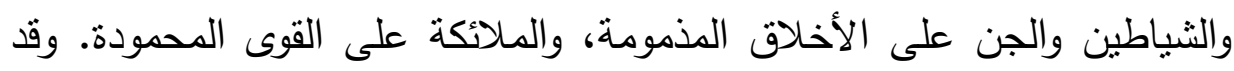
أجمعت الأمة في الصدر الأول على الأخذ بهذه الظواهر من غير تأويل. وإذاذا

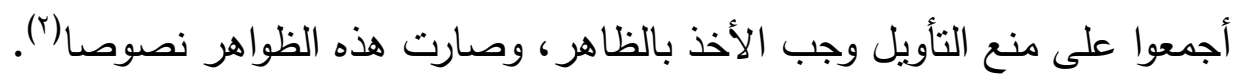
والأرجح هو القول الأول وهو الذي دلت عليه النصوص وأيدته الآثار

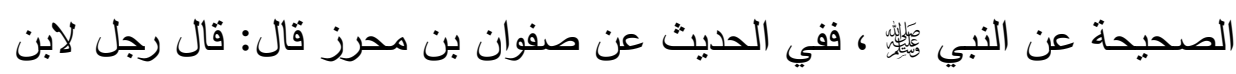
عمر : كيف سمعت رسول الله صلى الله عليه وسلم في النجوى؟ قال سمعته يقول: يدنى المؤمن يوم القيامة من ربه عز وجل، حتى يضع عليه كنفه، فيقرره بذنوبه، فيقول: هل تعرف؟ فيقول: أي رب أعرف، قال: فإني قد سترتها عليك في الدنيا،

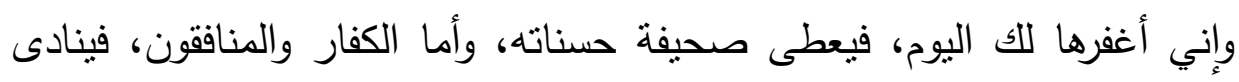
بهم على رعوس الخلائق هؤلاء الذين كذبوا على الهه"(r).

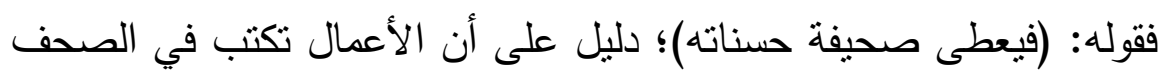
وتوزن (ई).

وفي سنن ابن ماجه عن عبد الله بن عمرو، يقول: قال رسول الهه صلى الله عليه وسلم: " يصاح برجل من أمتي يوم القيامة على رعوس الخلائق، فينشر لله بله له

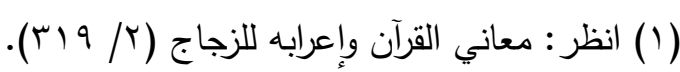

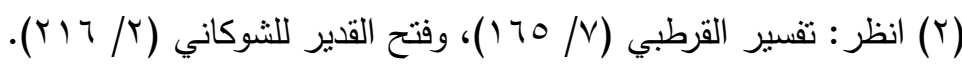

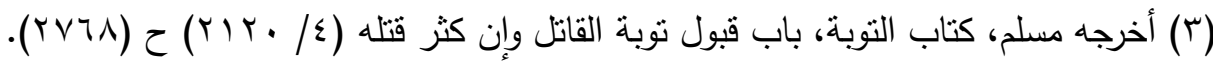

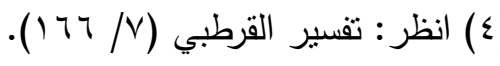




\section{د. ف فهر صالح الخنه}

تسعة وتسعون سجلا، كل سجل مد البصر، ثم يقول الله عز وجل: هل تتكر من هذا شيئا؟ فيقول: لا، يا رب، فيقول: أظلمتك كتبتي الحافظون؟ فيقول: لا، ثم يقول: ألك عذر، ألك حسنة؟ فيهاب الرجل، فيقول: لا، فيقول: بلى، إن للك عندنا حسنات، وإنه لا ظلم عليك اليوم، فتخرج له بطاقة فيها: أشهد أن لا إله إلا الله، وأن محمدا عبده ورسوله، قال: فيقول: يا رب ما هذه البطاقة، مع هذه السجلات؟ فيقول: إنك لا تظلم، فتوضع السجلات في كفة، والبطاقة في كفة، فطاشت السجلات، وثقلت البطاقة (1).

فقد تبين من هذا الحديث أن نقل الميزان وخفته يرجعان إلى وزن ما كتب فيه الأعمال لا نفس الأعمال، وأن الله سبحانه يخفف الميزان إذا أراد، وينقله إذا أراد بما يوضع في كفنيه من الصحف التي فيها الأعمال(؟). وهذا القول هو ما ذهب إلبه القرطبي ورجحه(ז)، وقال ابن الجوزي بعدما رجح هذا القول: (فإن قيل: أليس الله عز وجل يعلم مقادير الأعمال، فما الحكمة في وزنها؟ فالجواب: أن فيه خمس حكم: إحداها: امتحان الخلق بالإيمان بذلك في الدنيا. والثانية: إظهار علامة السعادة والثقاوة في الأخرى. والثالثة: تعربف العباد ما لهم من خير وشر • والرابعة: إقامة الحجة عليهم. والخامسة: الإعلام بأن الله

(1) أخرجه الترمذي، أبواب الإيمان، باب ما جاء فيمن يموت وهو يشهد أن لا إله إلا اله (10 (1)

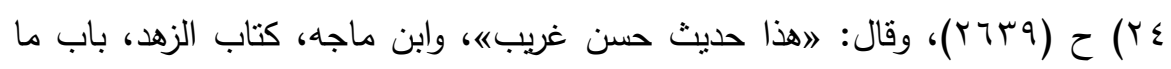

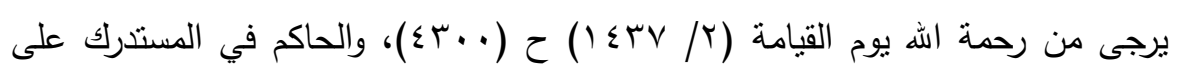

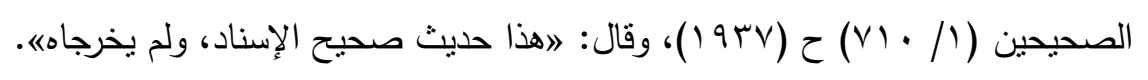

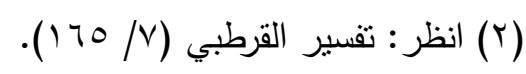

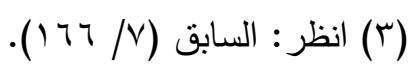


ع صور الحساب

عادل لا يظلم. ونظير هذا أنه أثبت الأعمال في كتاب، واستتسخها من غير

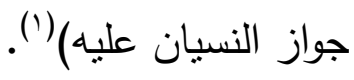

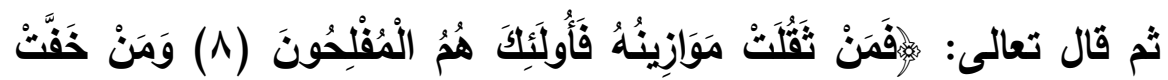

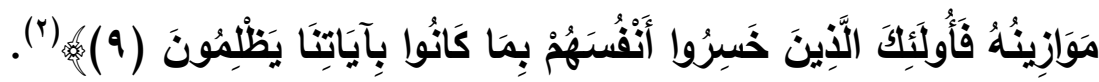

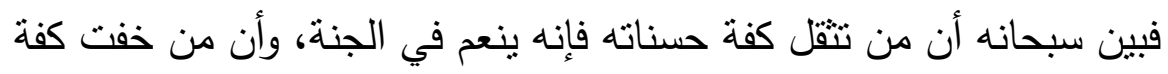

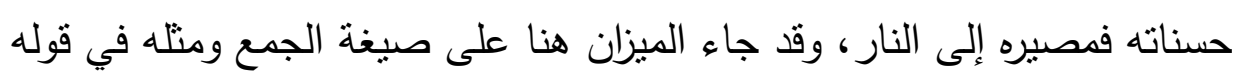

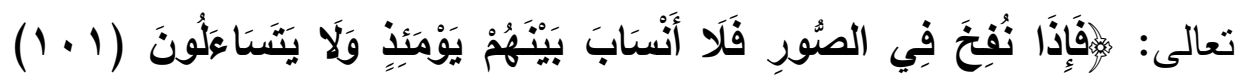

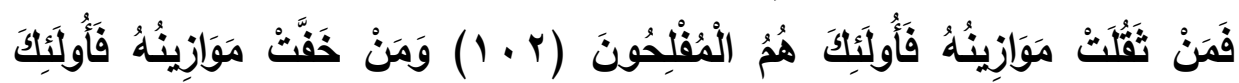

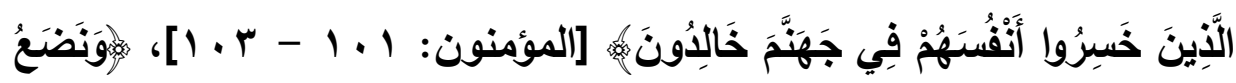

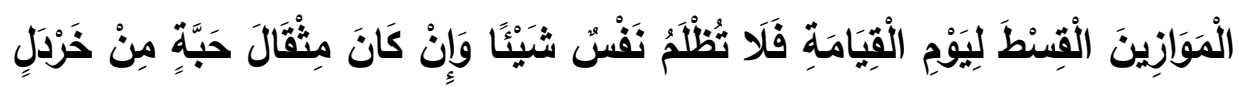

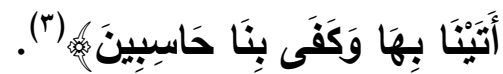

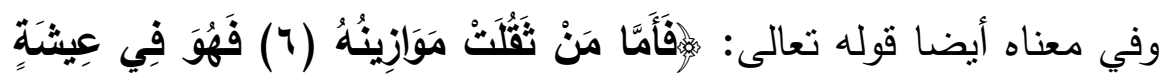

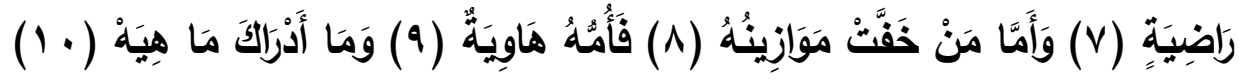

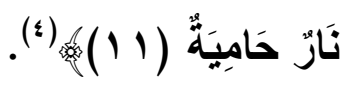
قال الرازي: (واعلم أن في الموازين قولين: أنه جمع موزون وهو العمل الذي واني

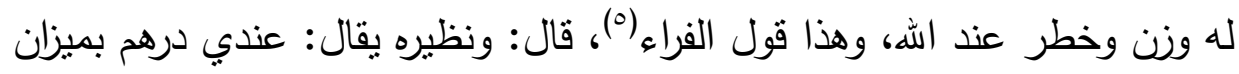

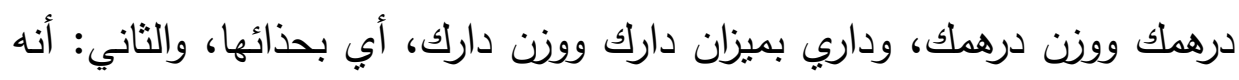

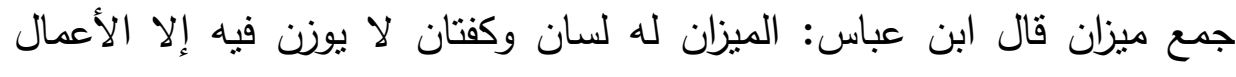

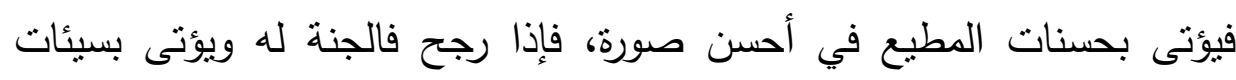

$$
\begin{aligned}
& \text { (1) زاد المسير في علم التفسير (Y/ \& • (1). }
\end{aligned}
$$

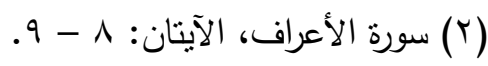

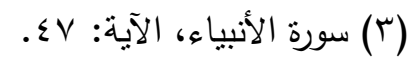

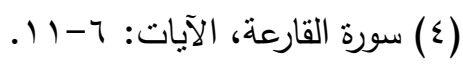

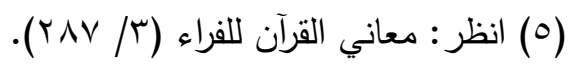




\section{د. د فه صالح الخنه}

الكافر في أقبح صورة فيخف وزنه فيدخل النار • وقال الحسن: في الميزان له كفتان ولا يوصف)(')

ويؤيد هذا التفسير حديث أبى بكر لعمر رضى الله عنهما في وصيته له: اوإنما ثقلت موازين من ثقلت موازينهم يوم القيامة باتباعهم الحق وتقلها في الدنيا،

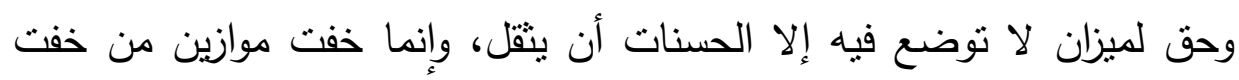
موازينه لاتباعهم الباطل وخفتها في الدنيا، وحق لميزان لا توضع فيه إلا السيئات

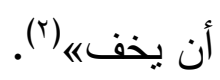

\section{وقد قيل في توجيه الجمع وجهان:}

الأول: أن العرب قد توقع لفظ الجمع على الواحد فيقولون: خرج فلان إلى

$$
\text { مكة على البغال. الأ. }
$$

والثاني: أن المراد من الموازين هاهنا جمع موزون لا جمع ميزان وأراد

$$
\text { بالموازين الأعمال الموزونة(؟). }
$$

والوجه الثاني ضعيف بقرينة وصف (القسط) الذي جاء صفة للميزان، والأعمال لا توصف بالقسط في هذا الموقف؛ لأن اله تعالى يزن كل الأعمال لا

ما كان قسطا منها فقط بدليل آخر الآيات(؛).

وذهب الرازي إلى أن ذلك عدول عن ظاهر اللفظ بدون موجب لذلك وقال:

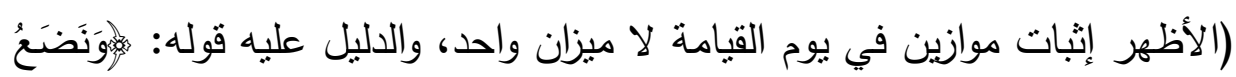

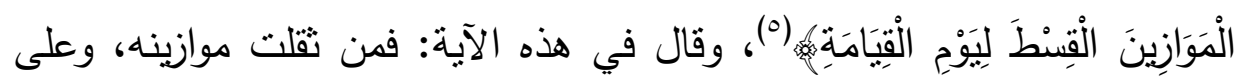

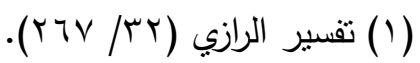

$$
\begin{aligned}
& \text { (Y) الزهد لأبي داود (ص: r) (Y). }
\end{aligned}
$$

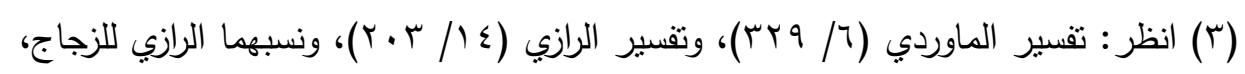
ولم أقف على ذلك في كتبه المتاحة.

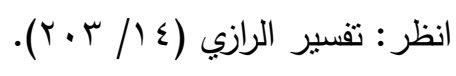

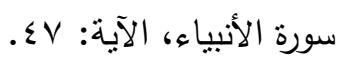


هذا فلا يبعد أن يكون لأفعال القلوب ميزان، ولأفعال الجوارح ميزان، ولما يتعلق

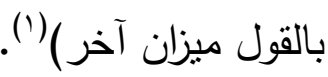

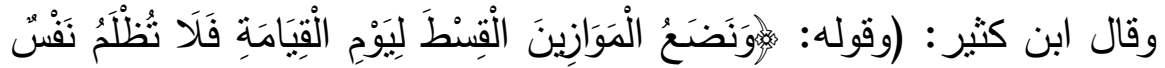

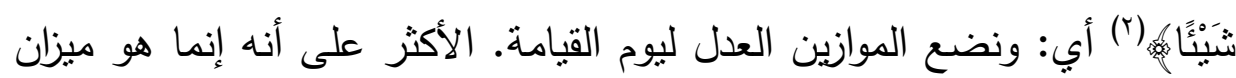
واحد، وإنما جمع باعتبار تعدد الأعمال الموزونة فيه) (†).

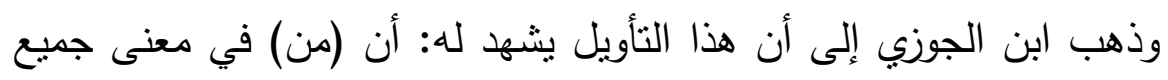

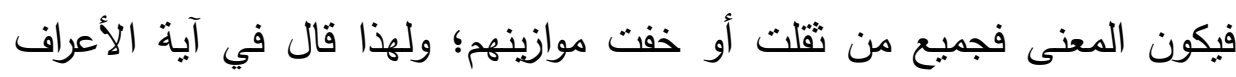
(فأولئك) بصيغة الجمع فعلم أن الموازين تعددت بتعدد أصحاب الأعمال أنفسهم (๕)

وهذا ما اختاره الراغب فقال: (وذكر في مواضع الميزان بلفظ الواحد اعتبارا بالمحاسب، وفي مواضع بالجمع اعتبارا بالمحاسبين) (०).

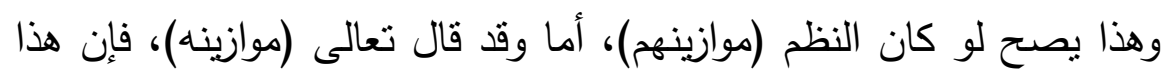
التأويل لا يصح. وقال القنوجي: (والموازين جمع ميزان، وهو يدل على أن هناك موازين، ألى

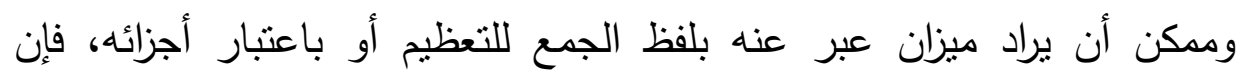
الصحيح أنه ميزان واحد لجميع الأمم ولجميع الأعمال)(1).

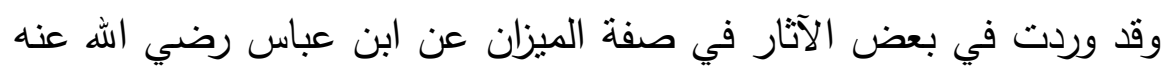

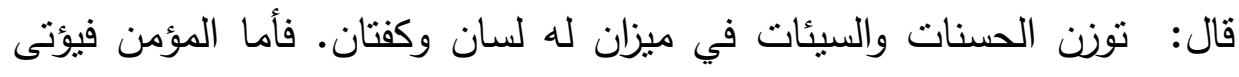

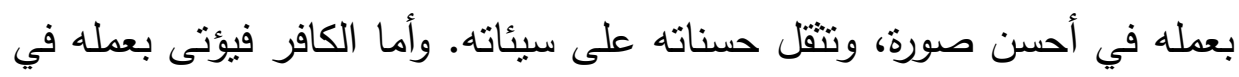

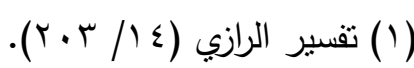

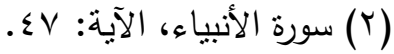

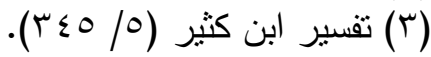

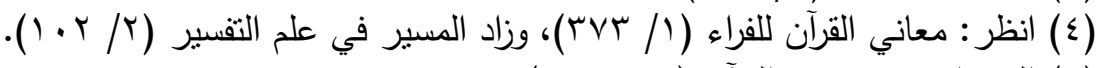

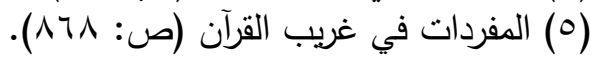

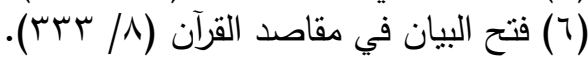

$$
\begin{aligned}
& \text {-ort- }
\end{aligned}
$$




\section{د. ف فه صالح الخنه}

أقبح صورة، وتتل سيئاته على حسناته('). وذكر الميزان عند الحسن: للميزان

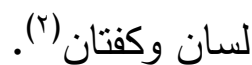
وقيل: إن داود عليه السلام سأل ربه أن يريه الميزان، فأراه إياه، فقال: يا إلهي، من يقدر أن يملأ كفتيه حسنات؟ فقال: يا داود، إني إذا رضيت عن إنه

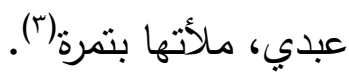
وقال حذيفة: جبريل صاحب الميزان يوم القيامة يقول له ربه: زن بينهم، ورد

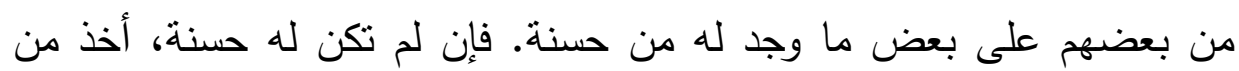
سيئات المظلوم، فرد على سيئات فيرد على المظلوم من الظالم الظالم، فيرجع وعليه منل الجبل (§). والخلاصة: أن الأعمال تكتب في صحائف وتوزن على العباد يوم في القيامة في ميزان الله تعالى أعلم بحقيقته وكيفيته، فتوضع حسنات العبد في كفة وتوضع سيئاته في كفة، فإذا رجحت كفت الحسنات فالعبد إلى الجنة، وإذا خفت هذه الكفة فرجحت السيئات فالعبد إلى النار إن كان كافرا فيخلا فيها، وهو في مشيئة الله إن إنى إنها

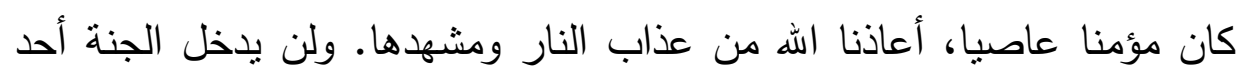

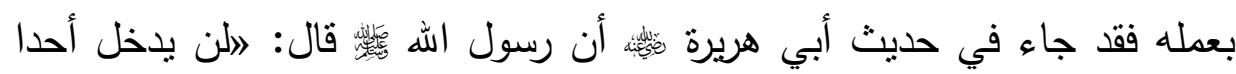
عمله الجنةه قالوا: ولا أنت يا رسول الله؟ قال: " لا، ولا أنا، إلا أن يتغدني الله

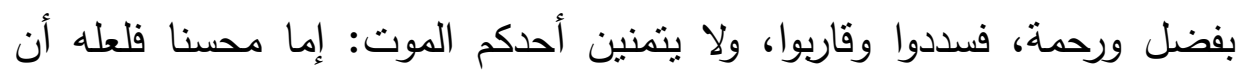

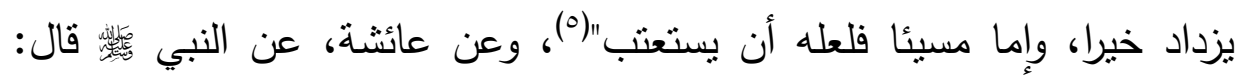

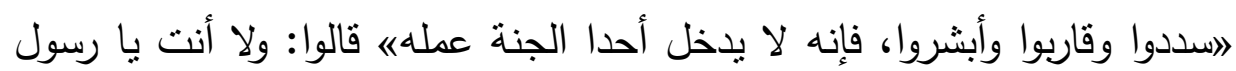

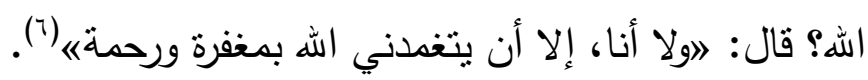

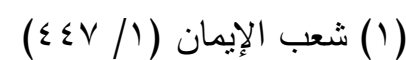

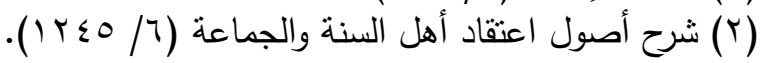

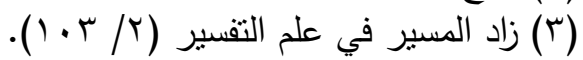

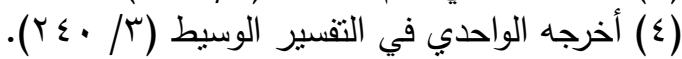

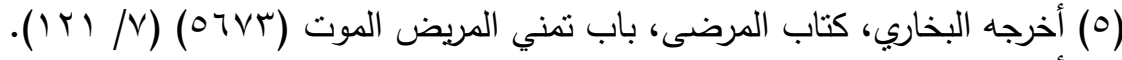

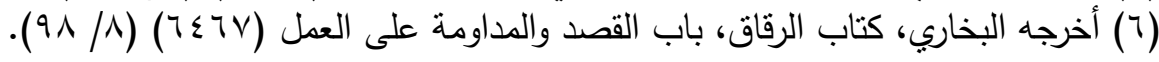




\section{المبحث السادس \\ إشهاد الجوارح}

كما اقتضت حكمة الله تعالى أن يكتب أعمال العباد عليهم حتى يذكرهم بها،

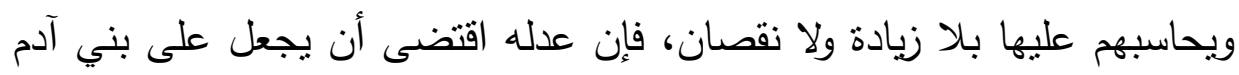

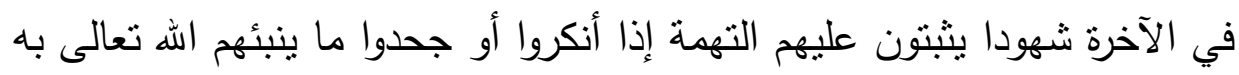
أو نسوه، فإن بعض الناس يوم القيامة ينكر ما يحاسبه الله عليه، فيجعل الله

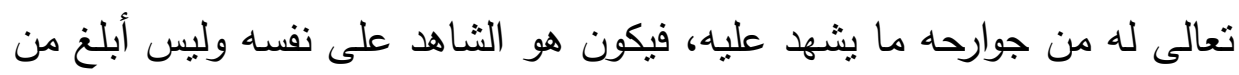
ذلك في الثهادة.

وقد ورد في هذا المعنى حديثُ أبي هريرة رضي اله تعالى عنه عن رسول

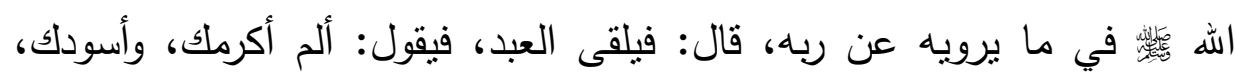

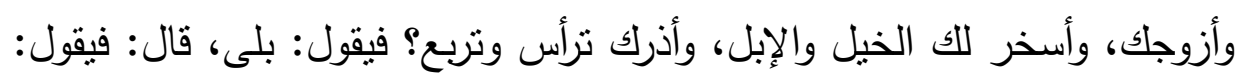
أفظنتت أنك ملاقي؟ فيقول: لا، فيقول: فإني أنساك كما نسيتني.

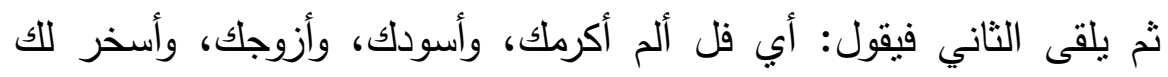

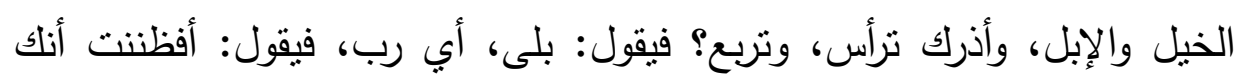
ملاقي؟ فيقول: لا، فيقول: فإني أنساك كما نسيتني.

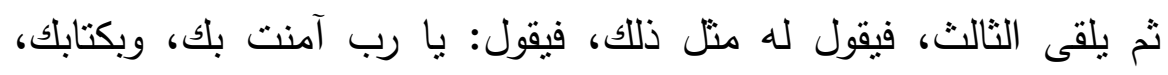
وبرسلك، وصليت، وصمت، وتصدقت، ويثي بخير ما استطاع، فيقول: هاهنا

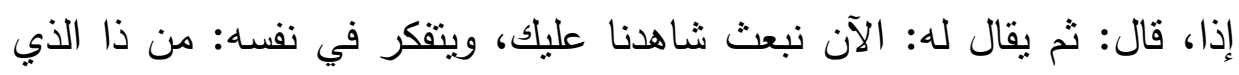

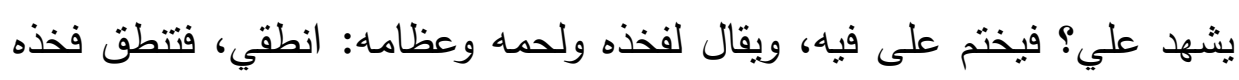
ولحمه وعظامه بعمله، وذللك ليعذر من نفسه، وذلك المنافق وذلك الذي يسخط الله ولها

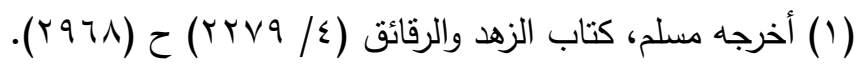

$$
\begin{aligned}
& \text {-ora- }
\end{aligned}
$$




\section{د. ف فه صالح الخنه ل}

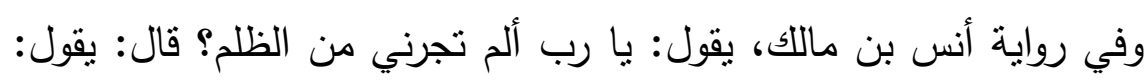

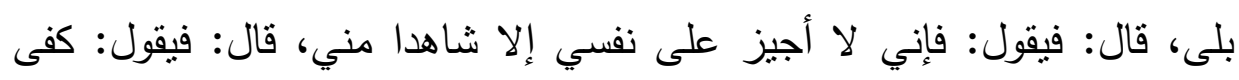

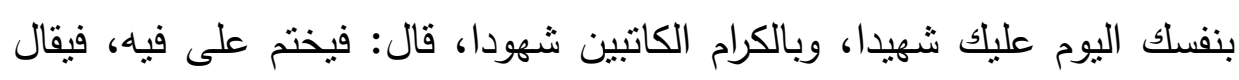

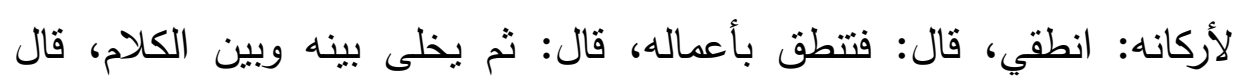

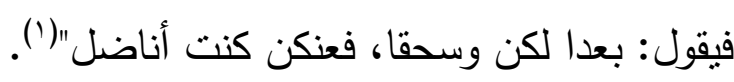
قال التوربشتي رحمه الله: (ليعذر على بناء الفاعل من الإعذار، والمعنى:

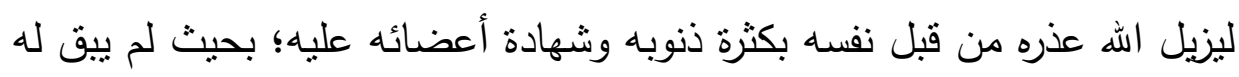
عذر يتمسك به) (r). وقال القرطبي: (المعنى أبلغ في الحجة؛ فإنه يقع نكذيبه من جوارحه، وتلك

غاية الخزي) (r)

ففي هذا الحديث إنشارة إلى قيام الحجة بشهادة أركان العبد عليه يوم القيامة،

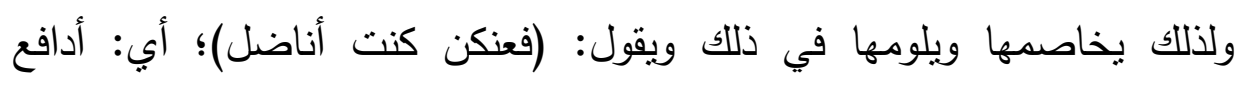
وأجادل وأخاصم وأننن تشهدن علي بعملي، يقول: أريد أن أدفع عنكن النار وأنتن تشهدن علي باستحقاق النار (ई).

وقد وردت آيات كثيرة في إنشهاد جوارح العبد عليه منها ما هو مجمل ومنها

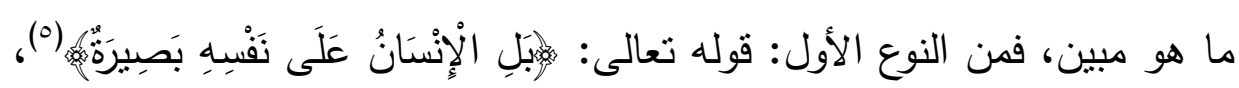

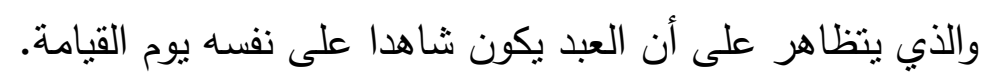

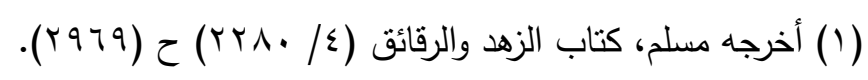

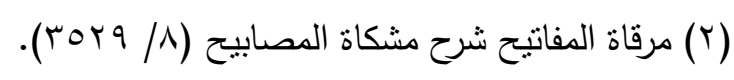

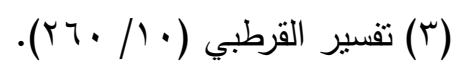

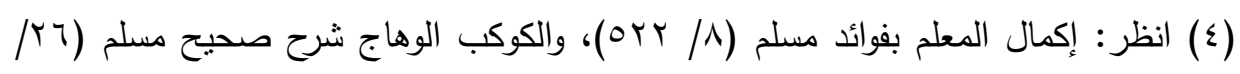


قال الطبري: (يقول تعالى ذكره: بل للإنسان على نفسه من نفسه رقباء

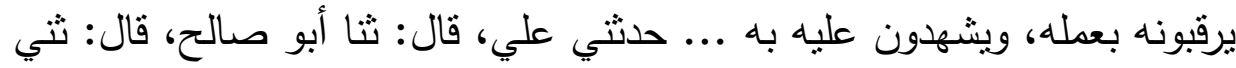

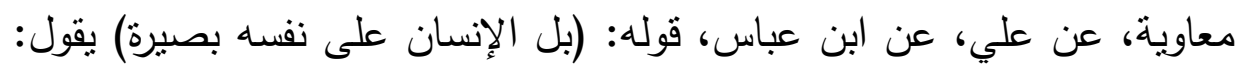
سمعه وبصره ويداه ورجلاه وجوارحه) (1).

وتحتمل هذه الآية معنى آخر هو: وقال الطبري: (وقال آخرونه آخرون: بل معنى ذلك: بل الإنسان شاهد على نفسه وحده، ومن قال هذا القول جعل البصيرة خبرا

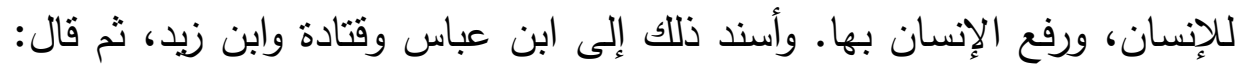
(ومن قال هذه الدقالة يقول: أدخلت الهاء في قوله (بصيرة) وهي خبر للإنسان،

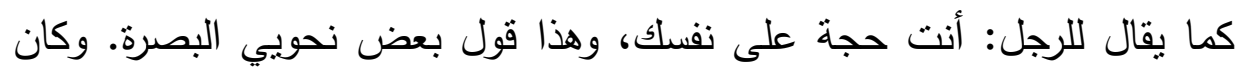
بعضهم يقول: أدخلت هذه الهاء في بصيرة وهي صفة انت للذكر، كما أدخلت في

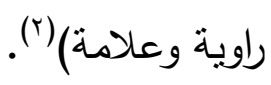

والحاصل أنها تدل على أن الإنسان شاهد على نفسه في الآخرة، فتكون هذه

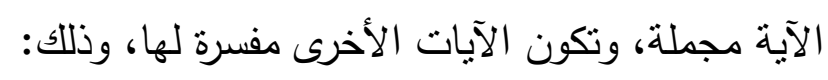

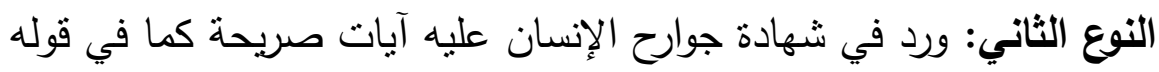

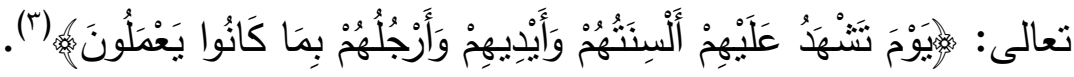
وهذه الثهادة خاصة بالكفار الذين ينكرون أفعالهم ويجحدونها، وقد ذكر الله

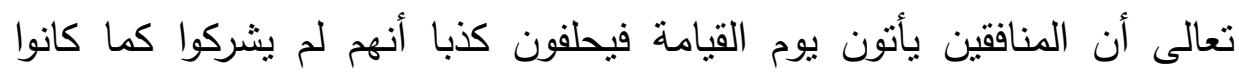

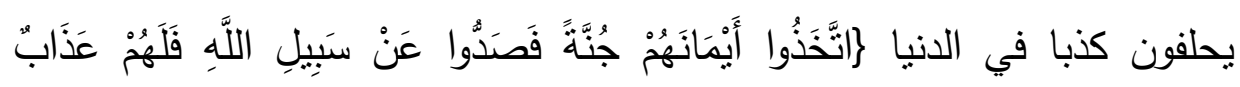

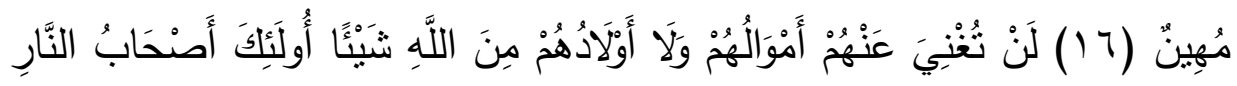

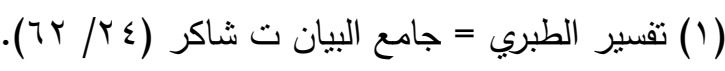

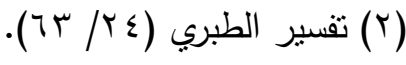

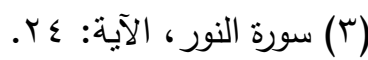




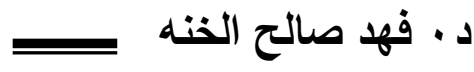

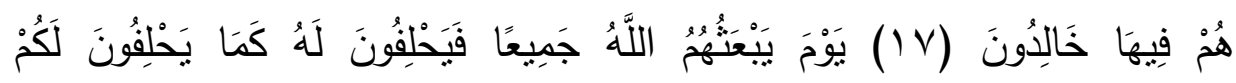

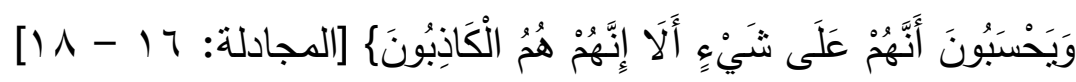

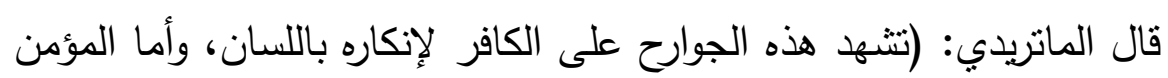

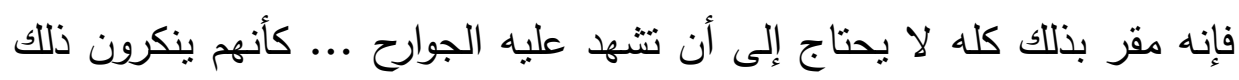

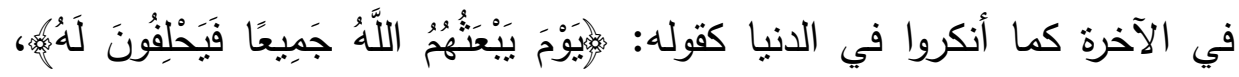

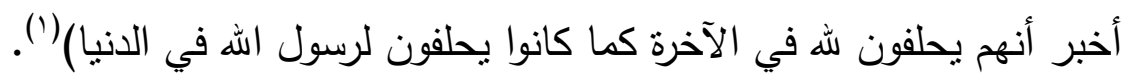

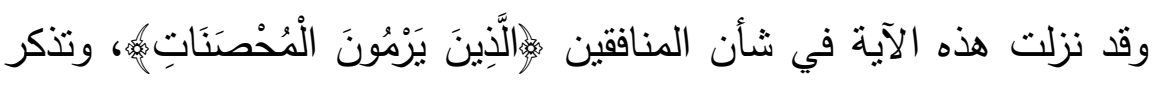

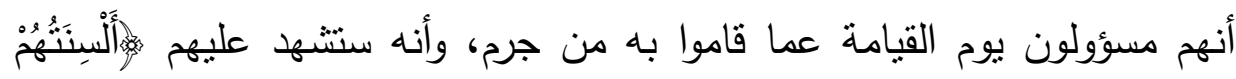

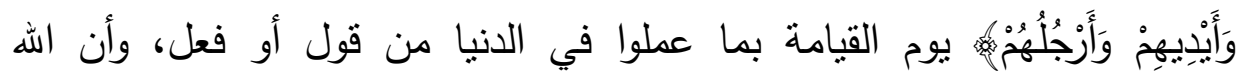

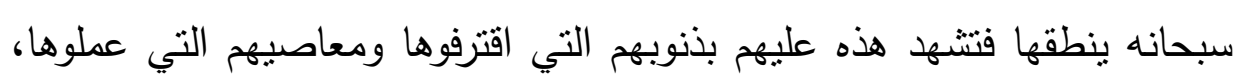

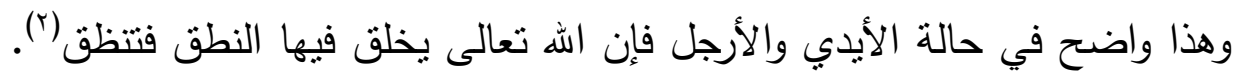
أما الألسن فقد ورد فيها تأويلان عن المفسرين: الأول: أن لسان كل كافر يشهد عليه بما فعل في الدنيا وهذا في حالة الكافر المقر .

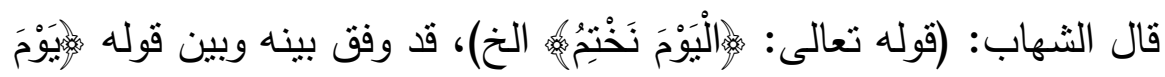

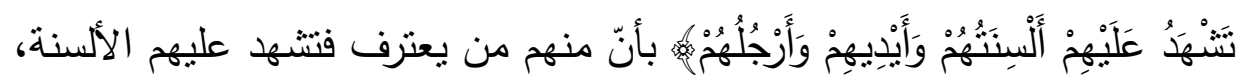
ومنهم من ينكر لقوله: الثاني: أن ألسن بعضهم تشهد على بعضهم فهم يشهدون على بعضهم

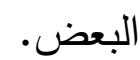

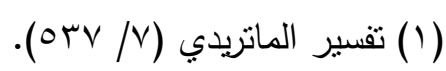

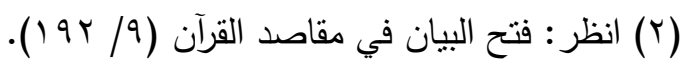

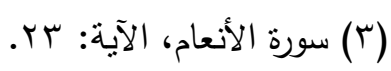

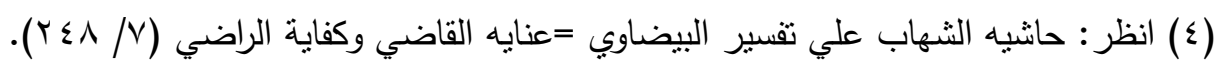


قال الطبري: (حين يجحد أحدهم ما اكتسب في الدنيا من الذنوب، عند تقرير اله إياه بها فيختم الله على أفواههم، وتتهر عليهم أيديهم وأرجلهم بما كانوا يعملون. فإن قال قائل: وكيف تشهـ عليهم ألسنتهم حين يختم على أفواههم؟ قيل:

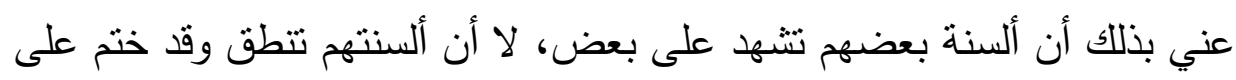

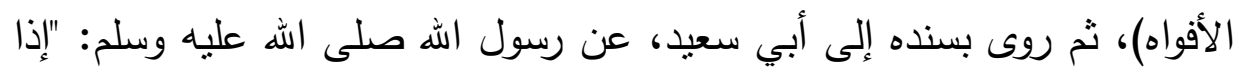

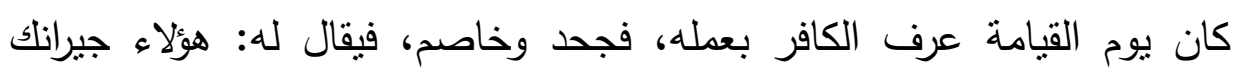
يشهدون عليك، فيقول: كذبوا، فيقول: أهلاك وعشيرتك، فيقول: كذبون وفيوا، فيقول: أتحلفون؟ فيحلفون، ثم يصنتهم الله، وتشهد ألسنتهم ثم يدخلهم النار) (').

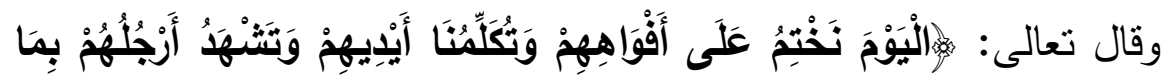

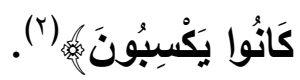
وهذه الآية أيضا تتبت شهادة الأيدي والأرجل على صاحبها يوم القيامة، فقد ذكر المفسرون أن الله تعالى يحشر المشركين يوم القيامة، وعندما يسألهم عن

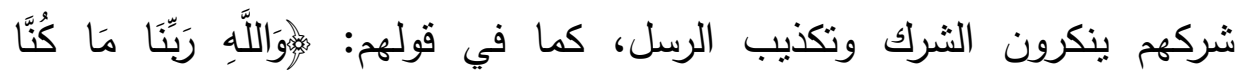

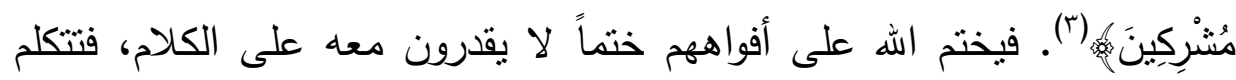

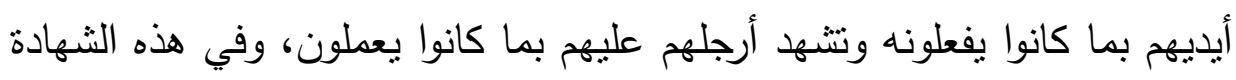

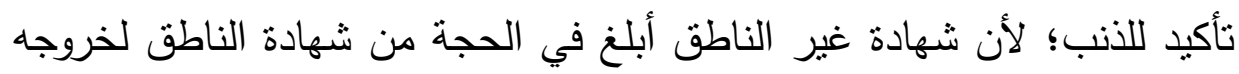

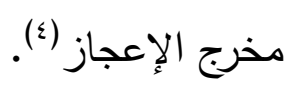

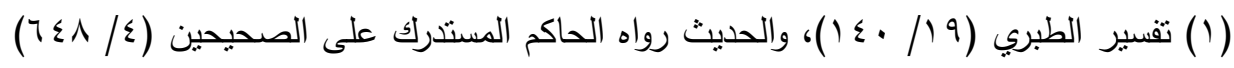

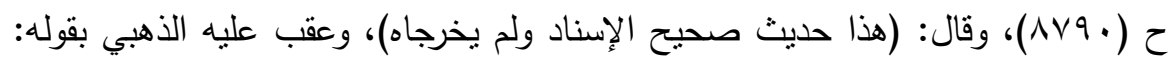

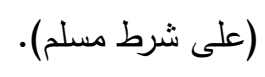

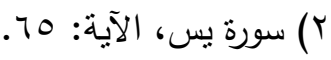

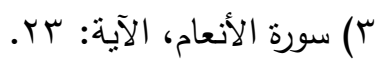

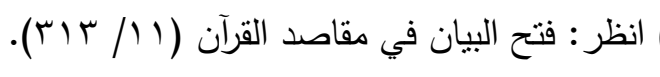




\section{د · فهر صالح الخنه}

قال الشوكاني: (وجعل ما تتطق به الأبدي كلاما وإقرارا؛ لأنها كانت المباشرة لغالب المعاصي، وجعل نطق الأرجل شهادة؛ لأنها حاضرة عند كل معصية، وكلام الفاعل إقرار، وكلام الحاضر شهادة، وهذا اعتبار بالغالب، وإلا فالأرجل قد

تكون مباشرة للمعصية كما تكون الأيدي مباشرة لها) (').

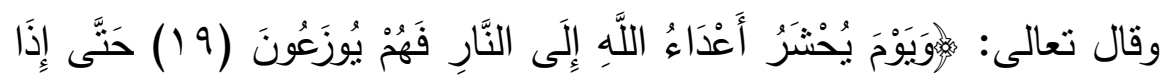

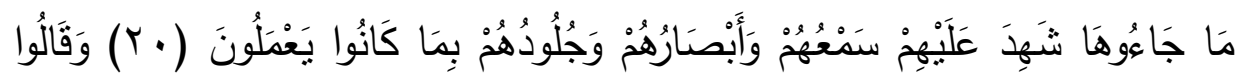

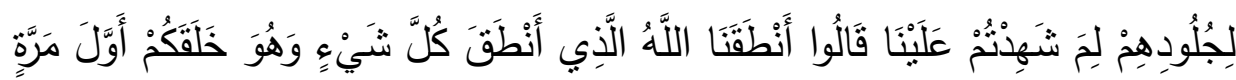

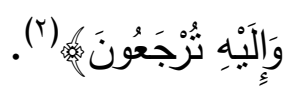

وهذه الآية تثبت شهادة للسمع والبصر والجلود على صاحبها يوم القيامة، فتصف حالا من أحوال الكفار في بعض أوقات القيامة، وذلك عند وصولهم إلى وهلى جهنم، فإن الله تعالى يسألهم سؤال توبيخ عن كفرهم فينكرون ذلك، ويحسبون أنه لا شاهد عليهم، ويظنون السؤال سؤال استقهام واستخبار ، فينطق اله تعالى هذه الجوارح جوارحهم بالثهادة عليهم(؟). وبالنظر إلى ما ذكر في هذه الآية يظهر أنها تعرضت لثلاث حواس من الإنسان وهي السمع والبصر واللمس، وأهملت ذكر نوعين وهما الذوق والثم، وقد ذكر بعض المفسرين في وجه تخصيصها: أن الذوق داخل في اللمس من بعض الوجوه؛ لأن إدراك الذوق إنما يتأتى بأن تصير جلدة اللسان مماسة لجرم الطعام، لهان

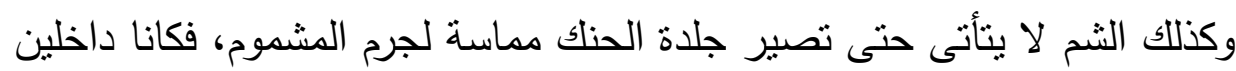
في جنس اللمس. ويفهم من معرفة وجه تخصيص الثلاثة بالذكر وجهُ تخصيص الجلود بالسؤال؛ لأنها قد اشتملت على ثناث حواس، فكان تأتي المعصية من

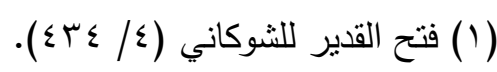

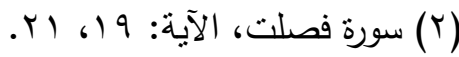

$$
\begin{aligned}
& \text { (r) انظر : تفسير ابن عطية = المحرر الوجيز في تفسير الكتاب العزيز (10 (1). } \\
& -0 \leqslant r-
\end{aligned}
$$


جهتها أكثر، وأما على قول من فسر الجلود بالفروج فوجه تخصيصها بالسؤال

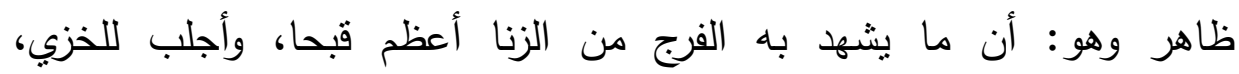

والعقوبة(1).

\section{كيفية شهادة الأعضاء على صاحبها:}

\section{اختلف المفسرون في كيفية شهادة هذه الأعضاء على صاحبها على}

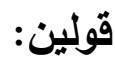

الأول: أن اله تعالى يخلق الفهم والقدرة والنطق فيها فتشهح كما يشهـ الرجل

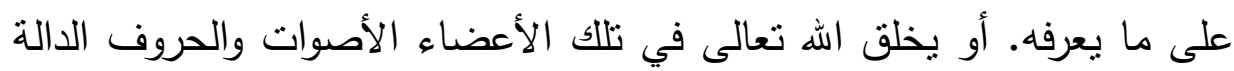
على تلاك المعاني. الثاني: أن يظهر في تلك الأعضاء أحوالا تدل على صدور تلأك الأعمال من ذلك الإنسان، وتلك الأمارات تنمى شهادات، كما يقال: العالم بشهـ بتغيرات أحواله على حدوثة (r). والأول هو الأرجح إذه هو الظاهر من لفظ الثهادة والتي هي حقيقة في

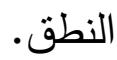
قال الزخشري: (فإن قلت: كيف تشهد عليهم أعضاؤهم وكيف تتطق؟ قلت: الله عز وجل ينطقها كما أنطق الثجرة بأن يخلق فيها كلاما. وقيل، المراد

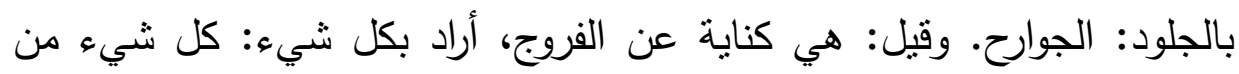

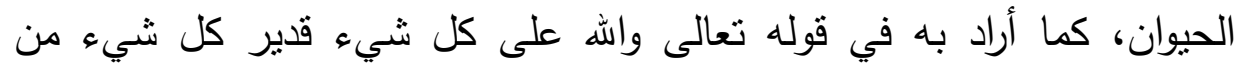

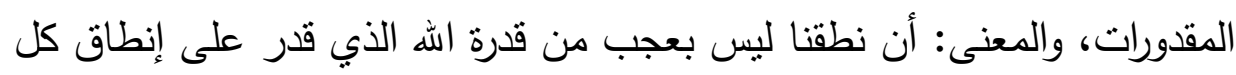
حيوان، وعلى خلقكم وإنشائكم أول مرة، وعلى إعادنكم ورجعكم إلى جزائه- وإنما

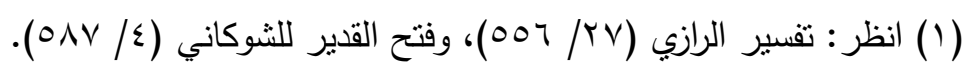

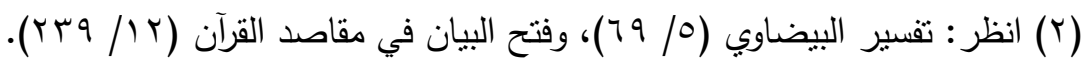

$$
\begin{aligned}
& \text {-0 }\{\leqslant-
\end{aligned}
$$




\section{د · فهر صالح الخنه}

قالوا لهم: لم شهدتم علينا لما تعاظمهح من شهادتها وكبر عليهم من الافتضاح على ألسنة جوارحهم)(')

قال الكرخي: (بنطقها الله تعالى كإنطاق اللسان فنتهـ. وليس نطقها بأغرب من نطق اللسان عقلاً، وإيضاحه أن البنية ليست شرطاً للحياة والعلم والقدرة، فاله تعالى قادر على خلق العقل والقدرة والنطق في كل جزء من أجزاء هذه الأعضاء)( العاء)

والحاصل: أن الكافر والمشرك إذ يجحد ما كتبه عليه الملائكة الموكلون بكتابة الأعمال فإن الله تعالى يشخِصُ لهم شهداء من أنفسهم يشهدون عليهم،

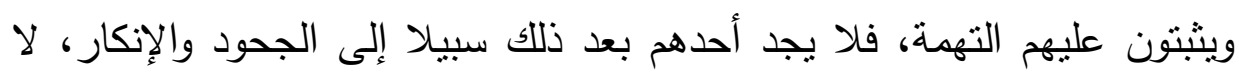
سيما والمولى تبارك وتعالى يختم على أفواههم فلا يستيطعون الكلام. وشهادة الجوارح هي الثهادة الخاصة التي تقع على المشرك والمنافق، وليست هي الثهادة الوحيدة التي تحصل يوم القيامة، وقد دل على ذلك قوله تعالى:

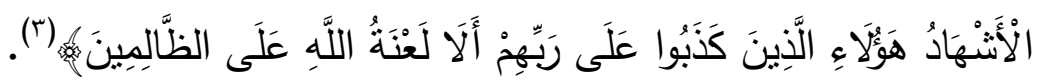

$$
\text { قال الرازي: الأشهاد أربعة: }
$$

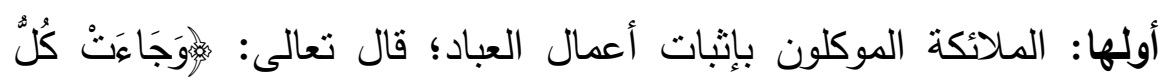

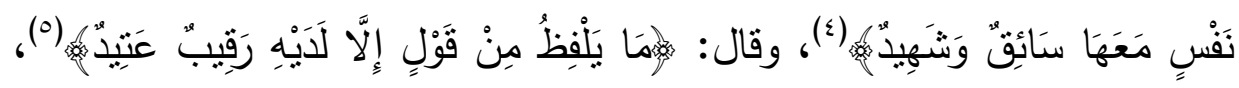

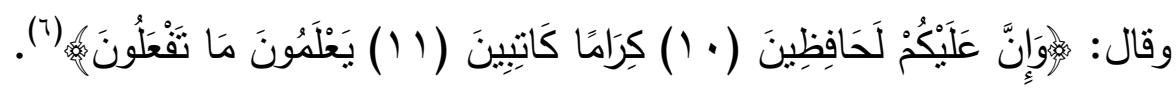

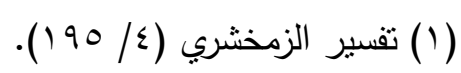

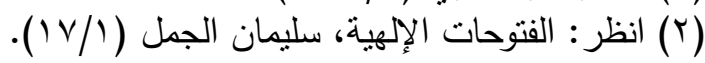

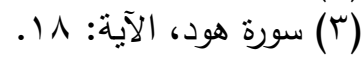

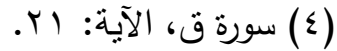

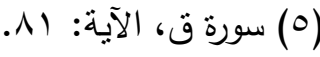

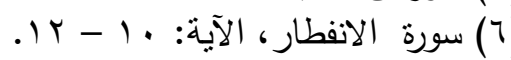




\section{=}

وثثانيها: شهادة الأنبياء وهو المراد بقوله حاكيا عن عيسى عليه السلام:

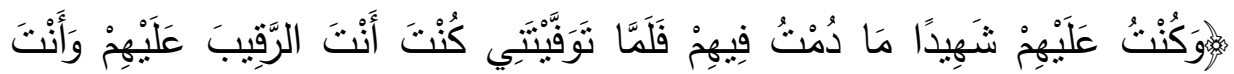

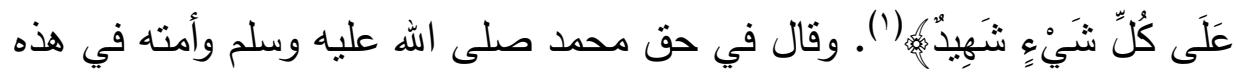

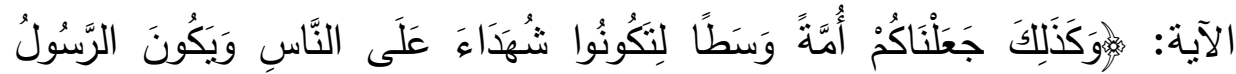

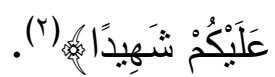

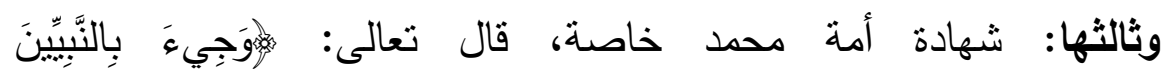

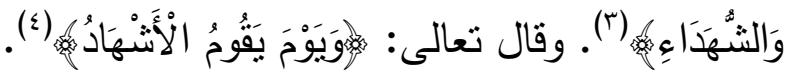

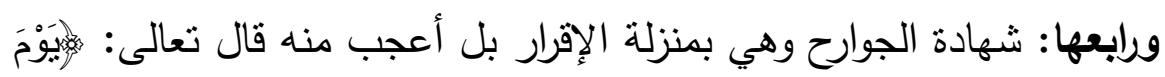

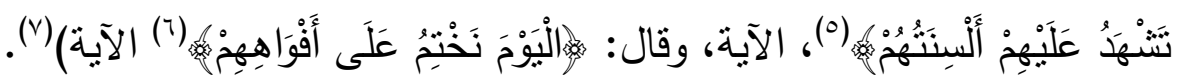

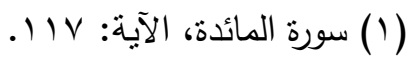

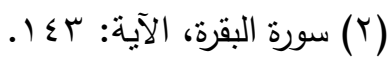

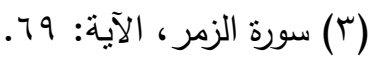

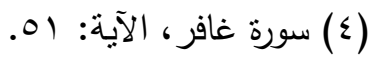

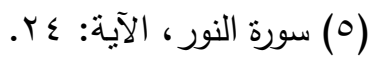

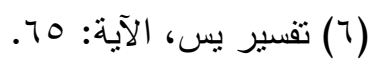

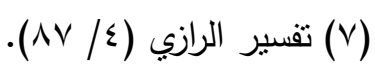


د. فهـ صالح الخنه ل

\section{المبحث السابع}

\section{أهل اليمين وأهل الثمال}

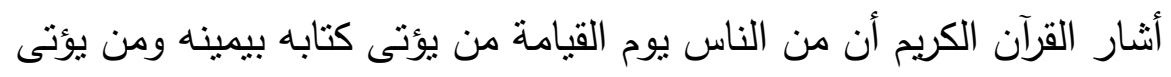

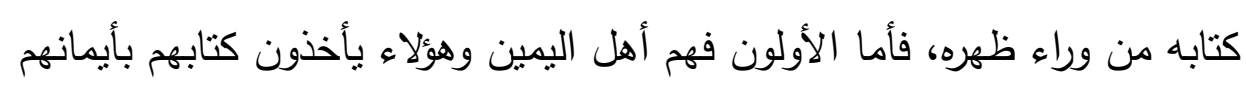
ويفرق بينهم وبين أهل النار فيقفون ذات اليمين. قال ابن كثير : (قوم عن يمين العرش، وهم الذين خرجوا من شق آدئن آدم الأيمن،

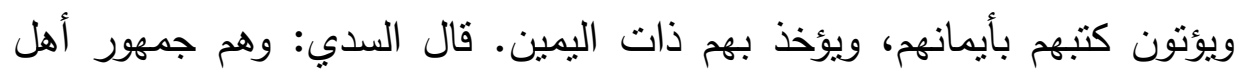

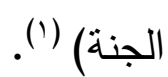
وأما الآخرون فهم أهل الثمال فهؤلاء يقادون إلى ذات الثمال ويأخذون كتبهم بشمائلهم وبساق بهم إلى النار أعاذنا الله منها.

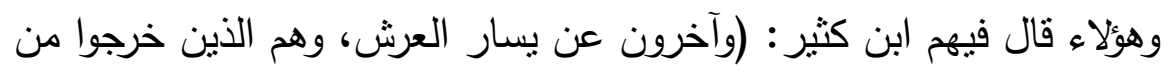

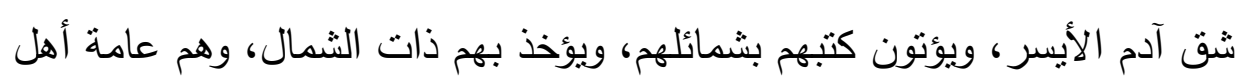
النار -عياذا بالله من صنيعهم)(ب).

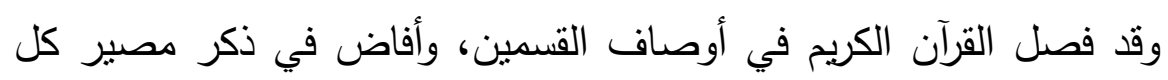

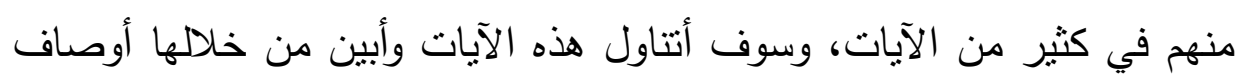
كل طائفة ومصيرها وسبب ما هي فيه من نعيم أو شقاء.

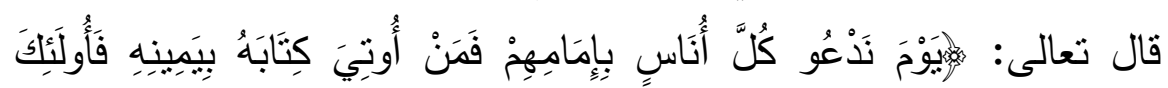

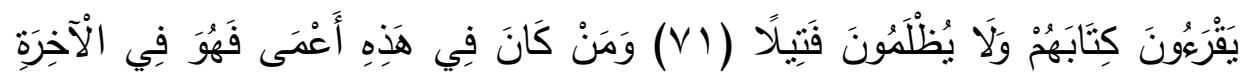

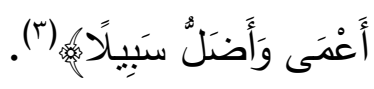

$$
\begin{aligned}
& \text { (1) تفسير ابن كثير (Y) (1) (1) ). }
\end{aligned}
$$

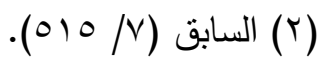

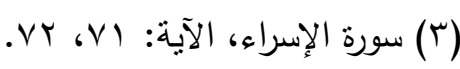


تتحدث الآيات الكريمة عن مصير الخلق يوم القيامة فكلهم يدعى بإمامهم

$$
\text { وقد ذكر المفسرون فيه ثلاثة وجوه: }
$$

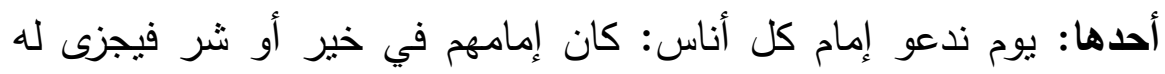

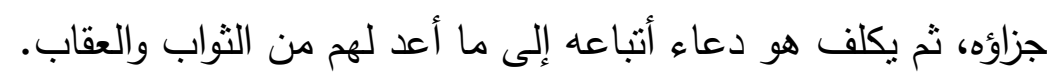

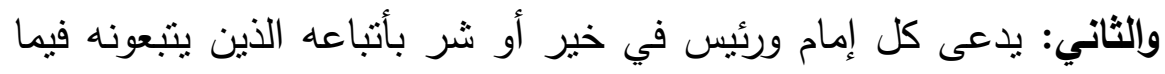
يدعوهم إليه نحو كل رسول يدعى بقومه الذين اتبعوه، وكل رئيس وشيطان استتبعهم.

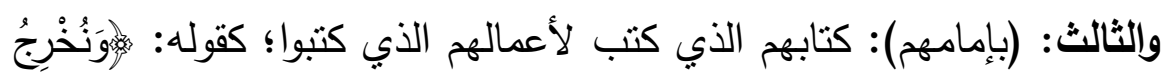

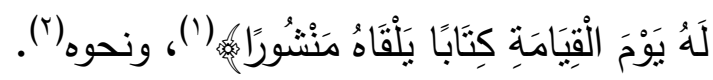

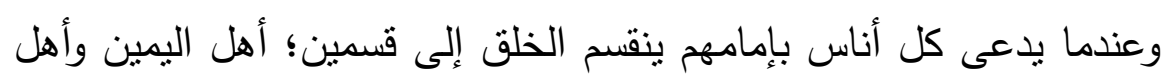

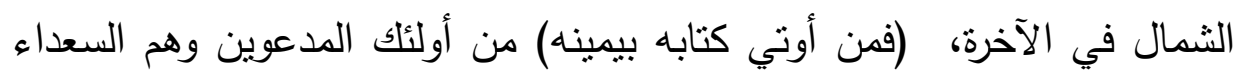

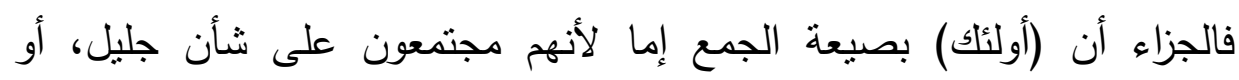

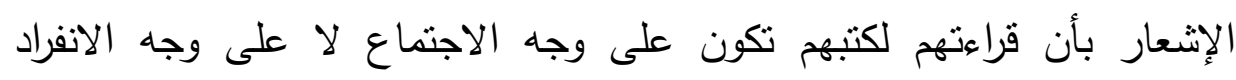

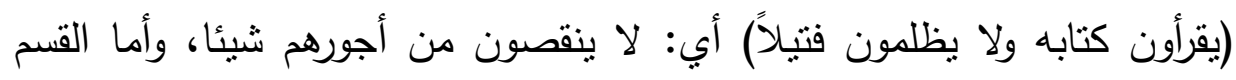

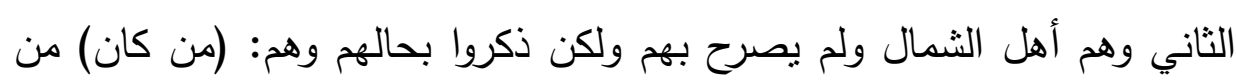
الددعوين (في هذه) الدنبا (أعمى) فجزاؤه أنه في الآخرة أعمى ().

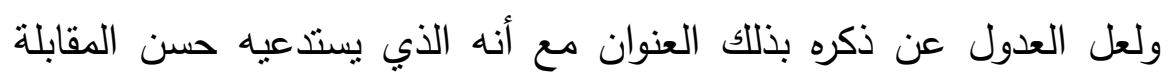

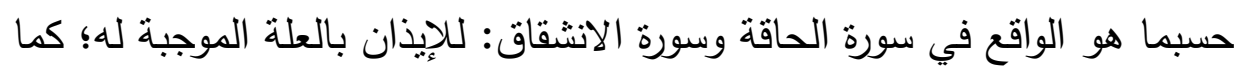

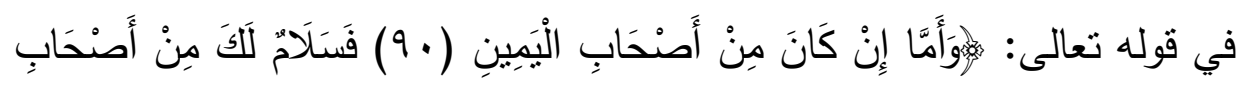

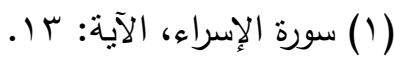

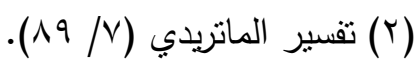

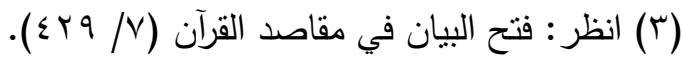$$
\text { - O }\{1-
$$ 


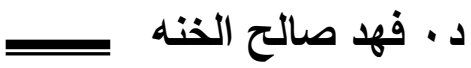

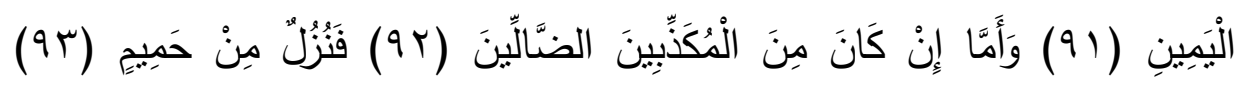

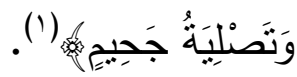

فجاء سبحانه وتعالى بوصف أهل الثمال وهو التكذيب في مقابل التصريح

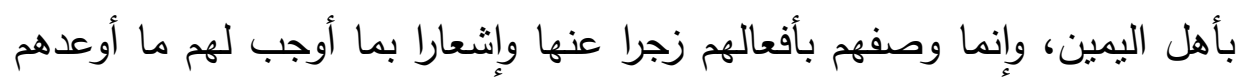
به بأه (r)

والضلال في هذه الآية بمعنى العىى في آية الإسراء، قال الرازي: (المراد من

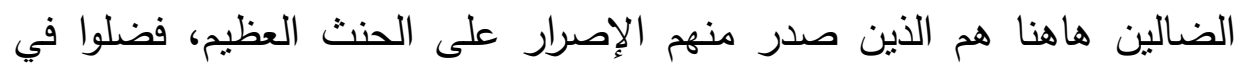
سبيل الهه ولم يصلوا إليه ولم يوحِّوه، وذللك ضلال عظين هنيم، ثم كذبوا رسله، وقالوا:

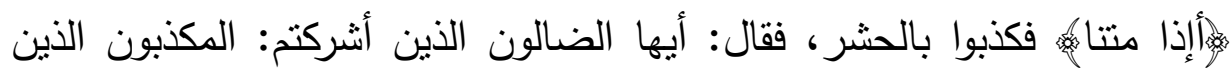
أنكرتم الحشر لنأكلون ما تكرهون) (r). وقال الطبري في معنى العمى في آية الإسراء: (معنى ذلك: ومن كان في

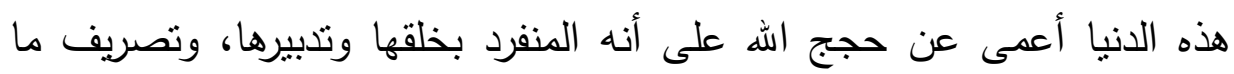

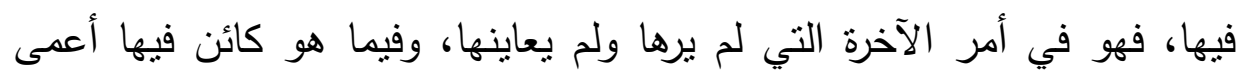
وأضل سبيلا، يقول: وأضل طريقا منه في أمر الدنبا التي قد عاينها ورآها) (؛). وقد ذكر الزمخشري وجها آخر في عدم ذكر قراءة أهل الثمال لكتابهه،

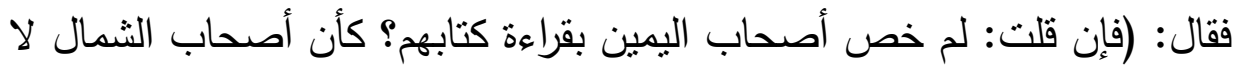

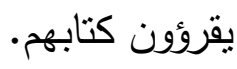
قلت: بلى، ولكن إذا اطلعوا على ما في كتابهم، أخذهم ما بأخذ المطالب

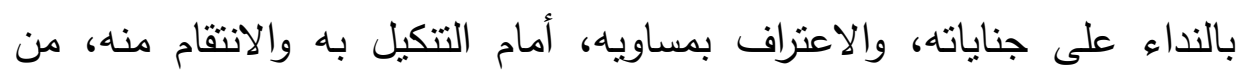

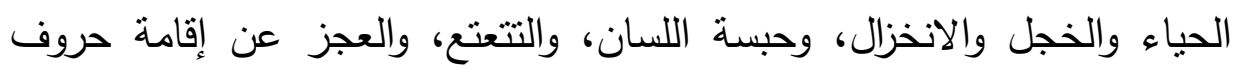

$$
\begin{aligned}
& \text { (1) سورة الواقعة، الآيات: .9 - } 9 \text { ـ } 9 .
\end{aligned}
$$

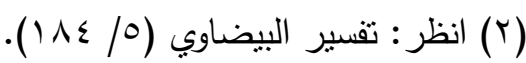

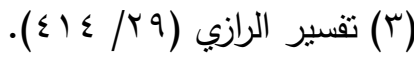

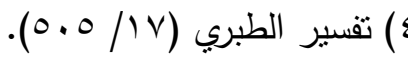


الكلام، والذهاب عن تسوية القول، فكأن قراءتهم كلا قراءة. وأما أصحاب اليمين فأمرهم على عكس ذللك، لا جرم أنهم يقرؤون كتابهم أحسن قراءة وأبينها، ولا لأل يقنعون بقراءتهم وحدهم حتى يقول القارئ لأهل المحشر : هاؤم اقرؤوا كتابيه) (').

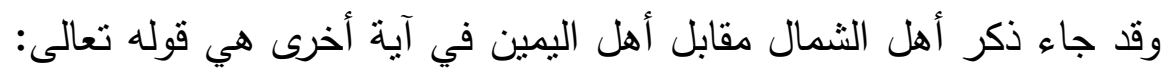

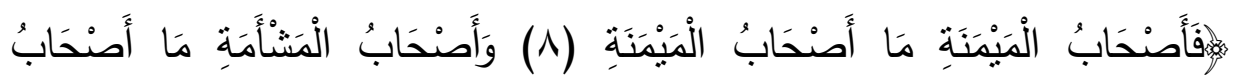

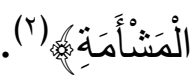
وجاء ذكرهم بأصحاب المشأمة؛ لثؤم الحال الذي يكونون فيه(؟)، أو كناية

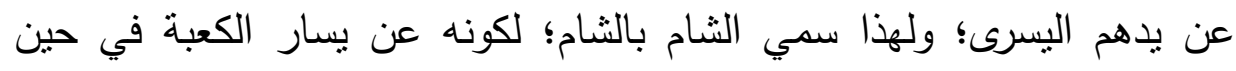

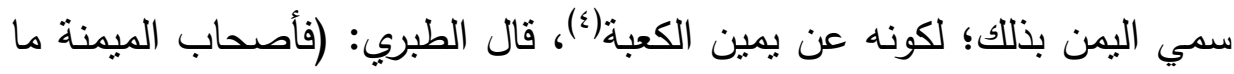

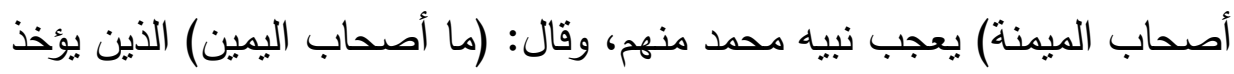

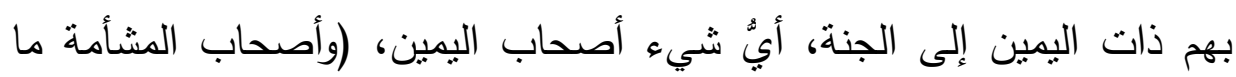

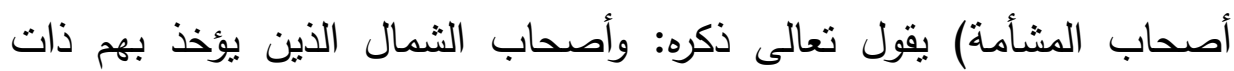

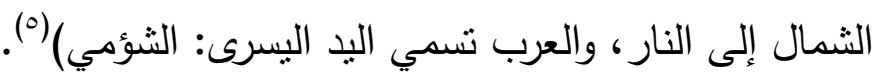

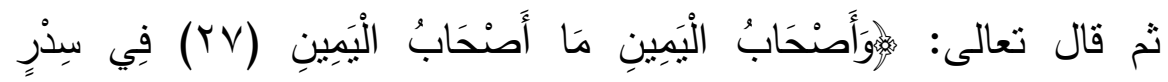

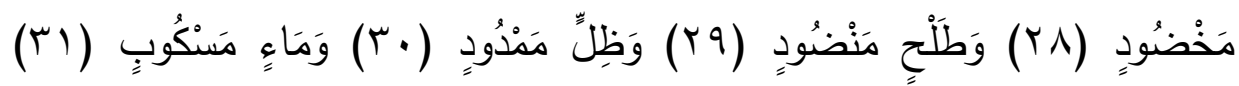

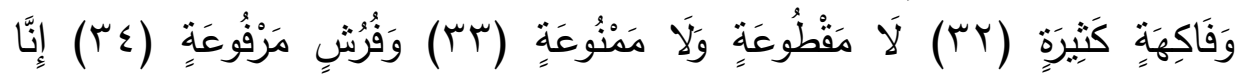

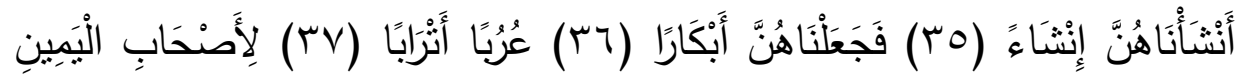

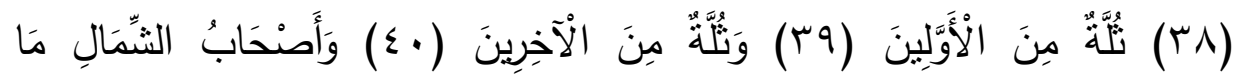

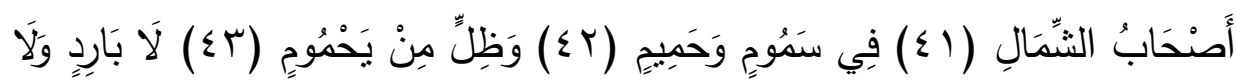

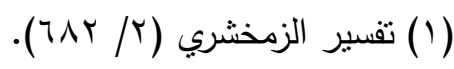
(Y) سورة الواقعة، الآية: ه، 9.

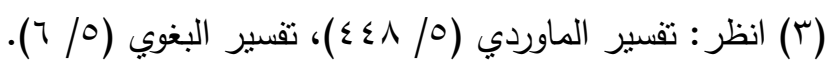

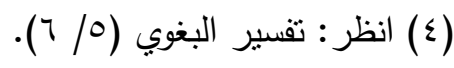

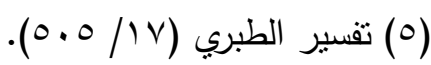




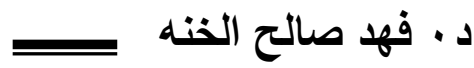

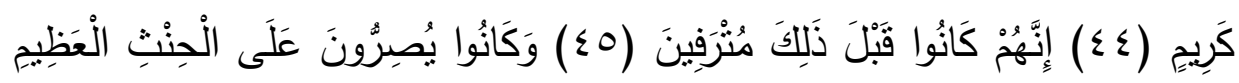

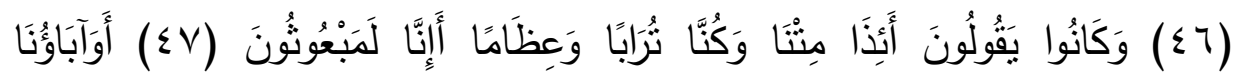

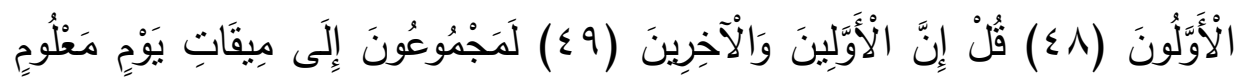
(1) $(0$.

وفي هذه الآيات يتحدث المولى تبارك وتعالى تفصيلا عن حال أهل اليمين

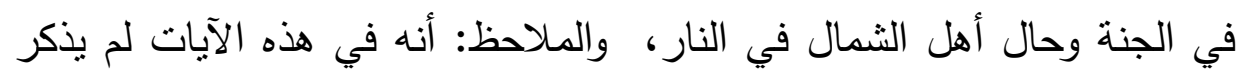

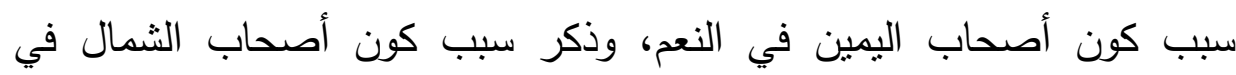

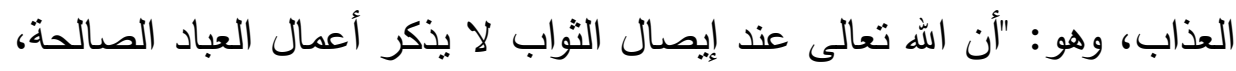

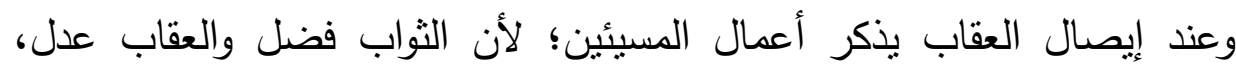

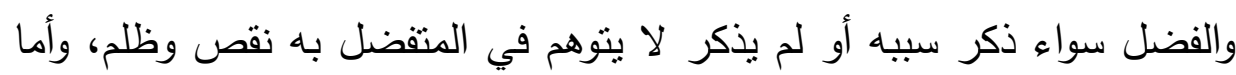

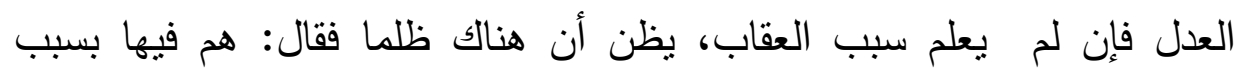

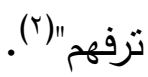

وفي هذه السورة ذكر المولى تبارك وتعالى عن أصحاب الثمال ثلاثة أحوال: الأول: أنهم أصحاب الثمال؛ فإنهم في الآخرة يؤنون كتابهم بشمالهم،

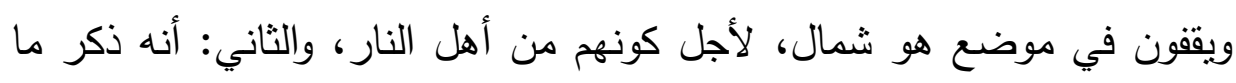

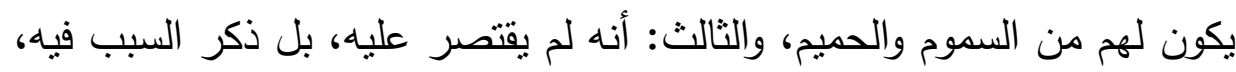
فقال: إنهم كانوا قبل ذلك مترفين وكانوا يصرون، فذكر سبب العقاب، فقال: وأما إن كان من المكذبين ليكون ترتيب العقاب على تكذيب الكتاب فظهر العدل (َ).

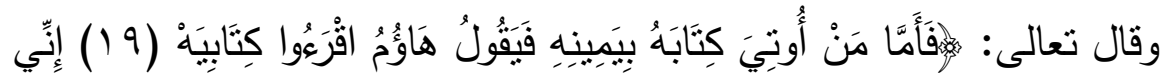

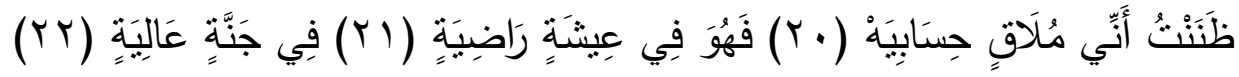

$$
\begin{aligned}
& \text { (1) سورة الواقعة، الآية: VV - - .0. }
\end{aligned}
$$

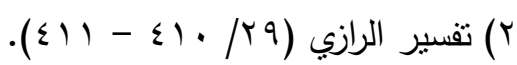

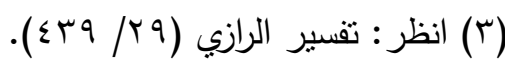




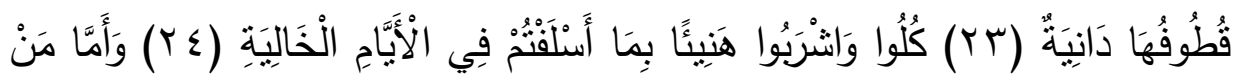

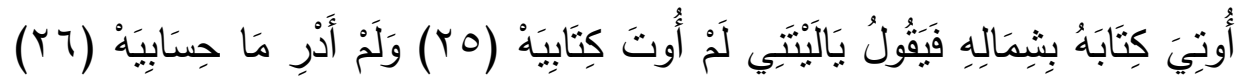

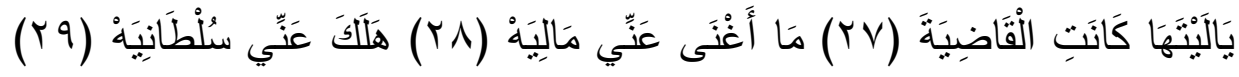

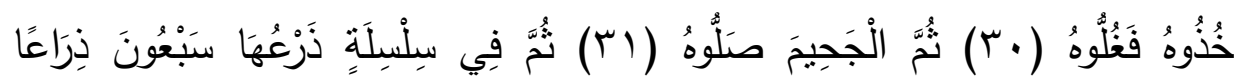

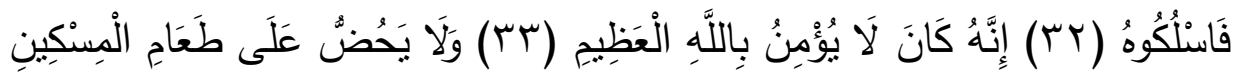

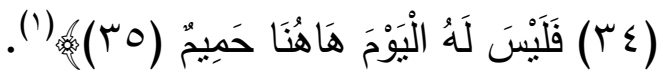
فعبر سبحانه عن أهل اليمين بسبب من أسباب تسميتهم بذلك وهو : أنهر يتتاولون كتابهم بأيمانهم، كما عبر عن أهل الثمال بأخذهم كتبهر بشمائلهم.

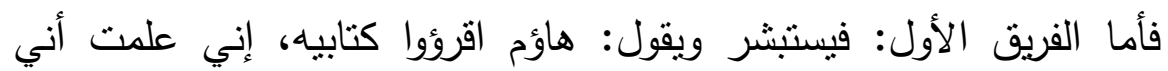

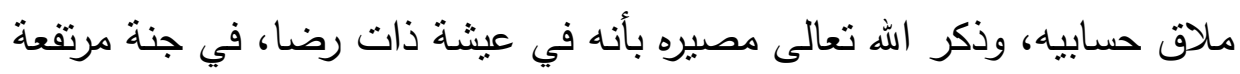

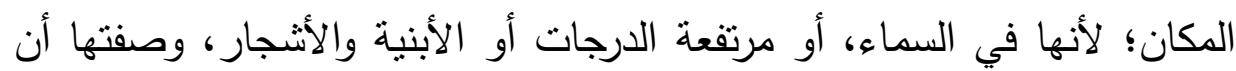

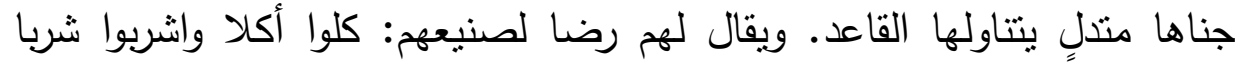

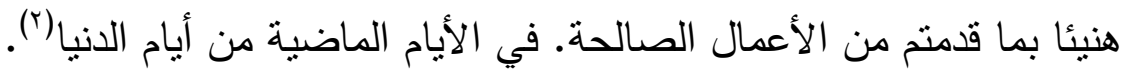

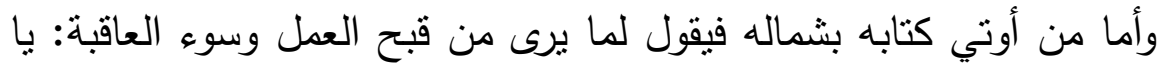

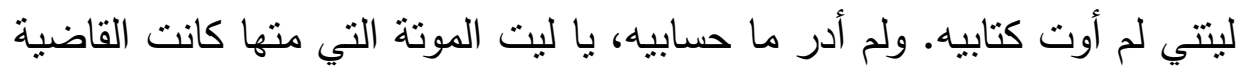

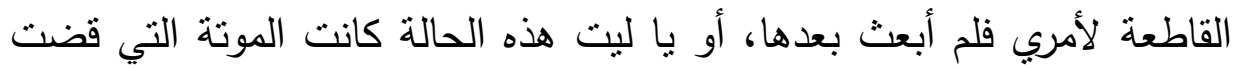

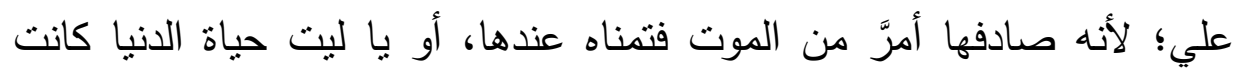

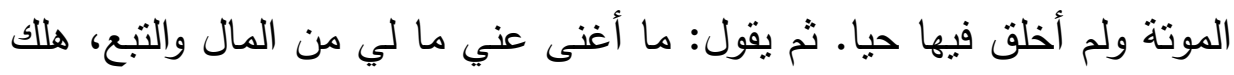

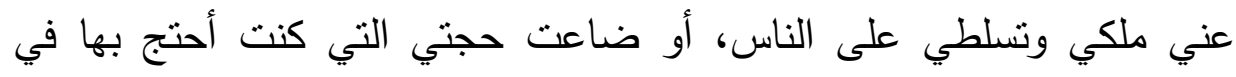

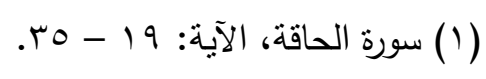

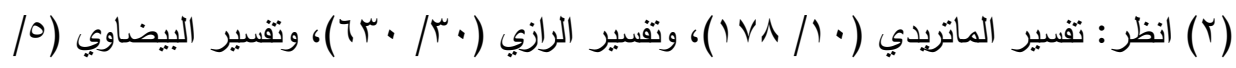




\section{د. ف فه صالح الخنه}

الانيا. ثم ذكرت مصيره ابتداء من قوله تعالى لخزنة جهنم: مارخذوه فغلوه .... ثم ذكر سبب ذلك وهو كفره بالله تعالى وعدم فعله للخيرات ('). قال البيضاوي: (ولعل تخصيص الأمرين بالذكر؛ لأن أقبح العقائد الكفر باله تعالى وأثنع الرذائل البخل وقسوة القلب)(r). وقال الزمخشري: (دليلان قويان على عظم الجرم في حرمان المسكين، أحدهما: عطفه على الكفر، وجعله قرينة له. والثاني: ذكر الحض دون الفعل، ليعلم أن تارك الحض بهذه المنزلة، فكيف بتارك الفعل!)().

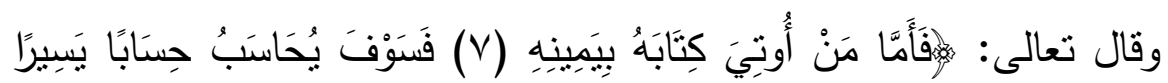

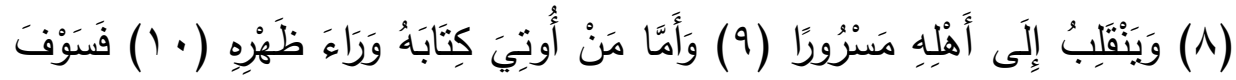

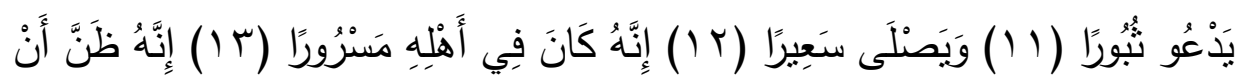

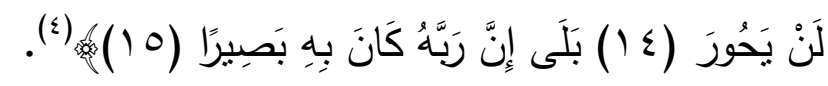
يذكر المولى تبارك وتعالى عاقبة من يأخذ كتابه بيمينه، وأنه يحاسب حسابا يسيرا، وقد بينت صفة الحساب اليسير قبلا، وأنه ههنا لا يناقش الحاسب فقد دلت لت لته السنة النبوية على أنه من يناقش الحساب يعذب.

قال الرازي: (والحساب اليسير هو أن تعرض عليه أعماله، ويعرف أن الطاعة منها هذه، والمعصية هذه، ثم يثاب على الطاعة ويُتجاوز عن المعصية، فهذا هو الحساب اليسير؛ لأنه لا شدة على صاحبه ولا مناقشة، ولا يقال له: لم وله فعلت هذا ولا بطالب بالعذر فيه ولا بالحجة عليه. فإنه متى طولب بذلك لم يجد عذرا ولا حجة فيفتضح، ثم إنه عند هذا الحساب اليسير يرجع إلى أهله مسرورا

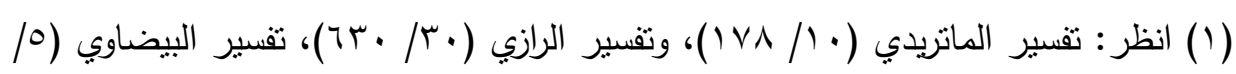

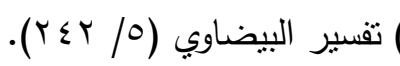

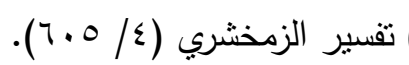

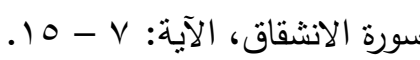




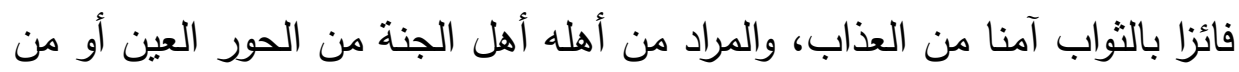

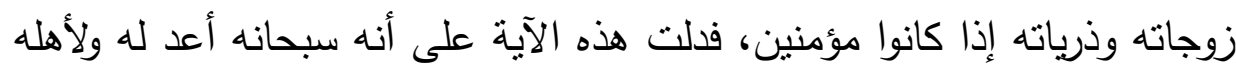

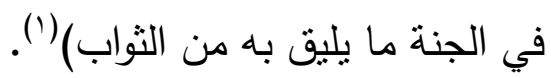
ثم تتعرض الآيات لصفة أهل الثمال، وهنا يذكر القرآن الكريم أن أحدهم يأخذ الكتاب من وراء ظهره، وللمفسرين فيه وجوه: الأول: قال الكلبي: السبب فيه؛ لأن يمينه مغلولة إلى عنقه ويده ولئه اليسرى خلف ظهره، وذهب إلى ذلك الطبري(؟). وثُانيها: قال مجاهد: تخلع يده اليسرى فتجعل من وراء ظهره("). وثالثها: ذهب بعض المفسرين إلى أنه بتحول وجهه في قناه

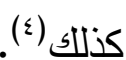

ورابعها: أنه يؤتى كتابه بشماله من وراء ظهره؛ لأنه إذا حاول أخذه بيمينه

كالمؤمنين يمنع من ذلك وأوتي من وراء ظهره بشماله (ه). وقد ذكر اله تعالى مصير من يأخذ كتابه بشماله من وراء ظهره فقال:

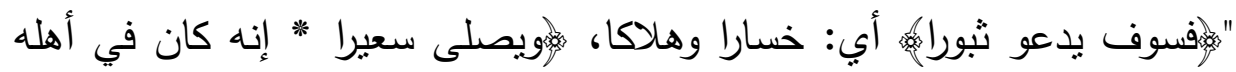

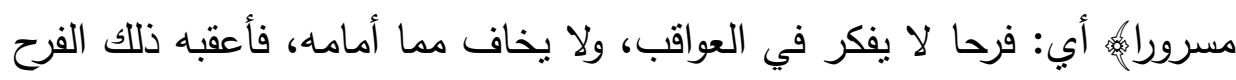

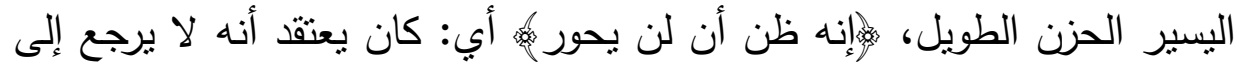
اله ولا يعيده بعد موته. قاله ابن عباس، وقتادة، وغيرهما. والحور: هو الرجوع.

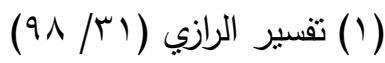

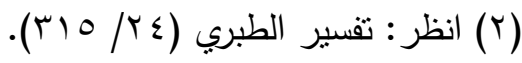

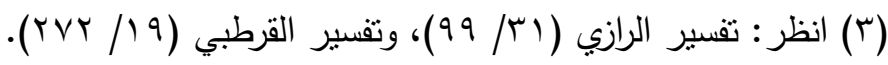

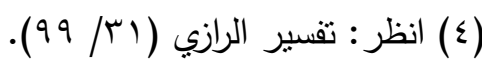

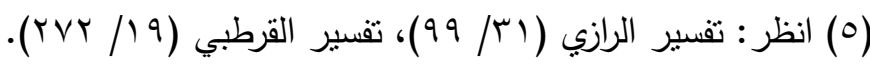

$$
\begin{aligned}
& -00 \varepsilon-
\end{aligned}
$$




\section{د · فهر صالح الخنه ل}

قال اله:

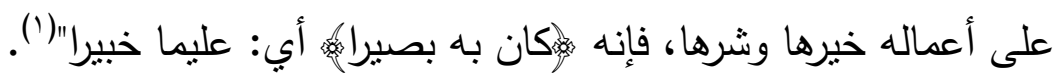

والخلاصة: أن الناس في الآخرة منهم من يتتاول كتابه بيمينه فهذا يستبشر

ويقرأ كتابه، فهذا هو المؤمن، وهذا إذا نظر في الكتاب - فرح به واستبشر بما فيه؛ فسهل عليه القراءة، فيقرأ كتابه مستبشرا ويدعو غيره لقراءة كتابه، وهذا أعد الله له جنات النعيم، ومنهخ من يتتاول كتابه بشماله من وراء ظهره، وهذا هو الكافر الذي إذا نظر في الكتاب حزن واغتم به؛ فعسر عليه قراءة كتابه، فيتمنى لو أنه لم يتتاول كتابه أو أن حياته انتهت إلى مرحلة لم تصل به إلى العذاب، وهذا أمره كما ذكر الله تعالى عذاب جهنم وبئس المصبر • جعلنا الله تعالى من أهل يمنه ويمينه، وجنبنا مصبر أهل الثمال. 


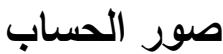

\section{المبحث الثامن}

\section{النظر إلى الأعمال ونطق الكتاب}

إذا كان العلم الحديث قد وصل إلى اختراعات استطاع بها أن بحفظ الصورة وأن يسجل الأصوات، فإن اله سبحانه وتعالى بقدرته أقدر على نشجيل كل أعمال البشر وعرضها عليهم في الآخرة.

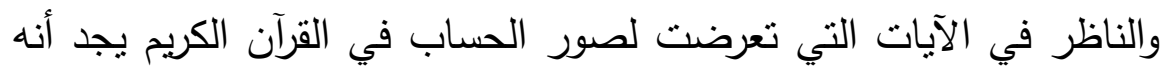
لا يجمل الحديث عن الحساب إجمالا تختفي فيه كثير من المعاني والتفاصيل، بل

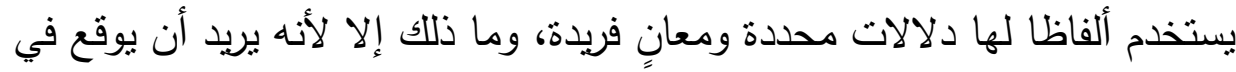
النفس معنى معينا.

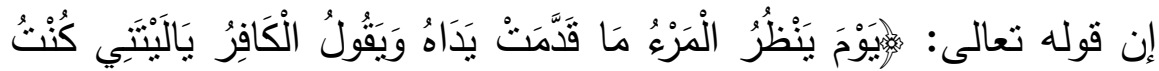

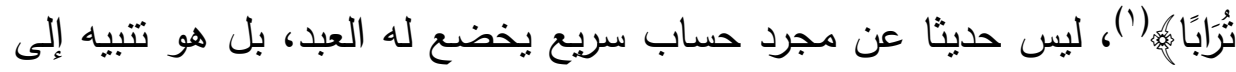

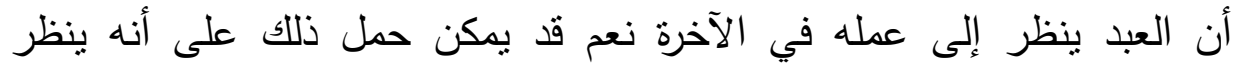
لصحيفته ويرى ما كتب فيها من أعماله.

لكن المتعمق في فهم هذه الآيات ودلالتها وما ورد في السنة الكريمة والمتنبر لصفات الله تعالى وعجائب قدرته وما بثه العلم الحديث، قد يتراءى له من المعاني ما هو أليق بنظم الآية وسياقها.

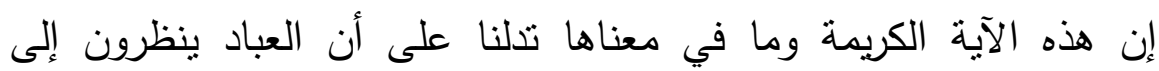

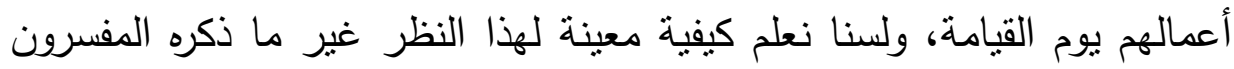

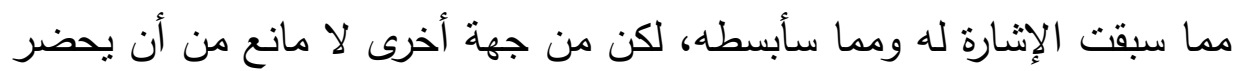

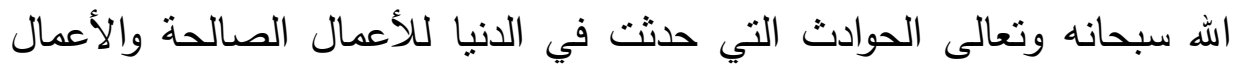

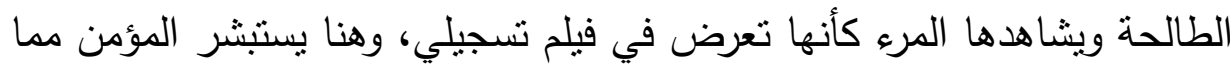

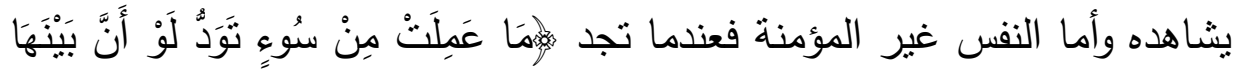




\section{د · فهر صالح الخنه}

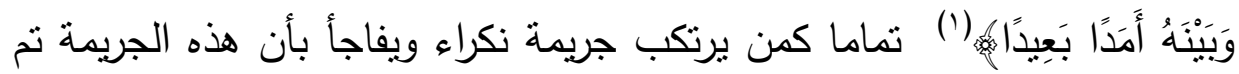
رصدها بكاميرات وعندما يشاهد نفسه بستخزي، ويتمنى لو كان بينه وبين هذا الفيلم أسوار وحصون تحميه وتمنعه. وهكذا يكون الحال في الآخرة ولا بُعد في ذللك، فالله سبحانه على كل شيء قدير، والعلم الحديث والتقنية الحديثة قد بلغت في ذلك مبلغا يقطع سبيل التعجب والإنكار

وأما ما عرضه المفسرون فقد قال بعضهم يَزِن الله سبحانه الأعمال حيث يحوّلها إلى أجرام وأجسام بعد أن كانت أعراضا، وينظر إليها العبد وتكون من الجسامة والضآلة بحسب طيبها وخبثها، غير أن الفارق بين عمل الصالح وعمل الطالح هو صورته.

قال أبو السعود: (وقد روي عن ابن عباس رضي الله عنهما أنه يؤتى

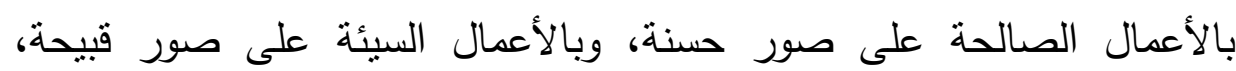
فتوضع في الميزان أي: فمن ترجحت مقادير حسناته) (؟). قال ابن كثير : (والذي يوضع في الميزان يوم القيامة قيل: الأعمال وإن كانت

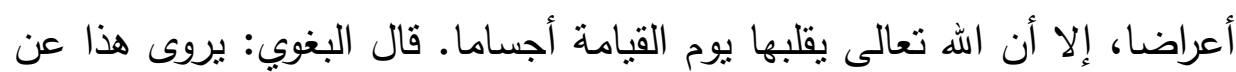

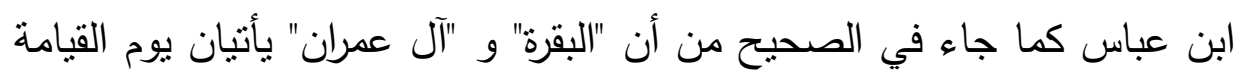

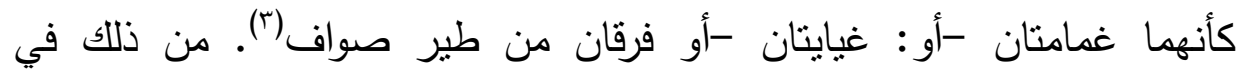
الصحيح قصة القرآن وأنه يأني صاحبه في صورة شاب شاحب اللون، فيقول: من من فين

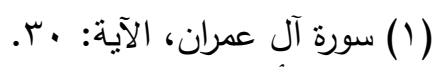

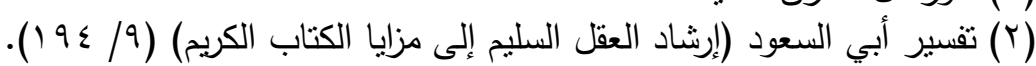

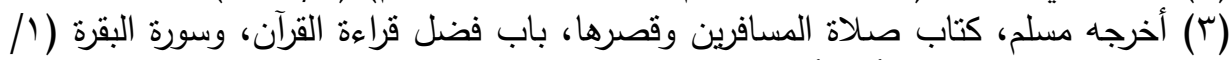

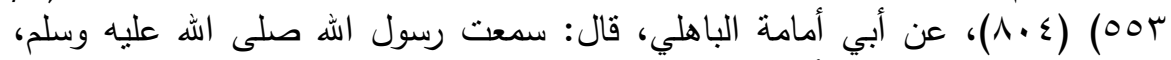

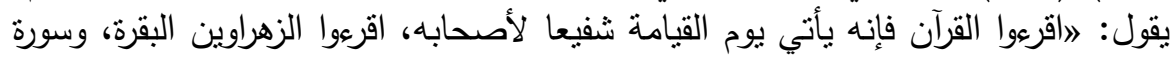

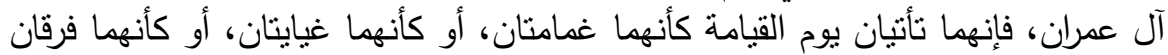

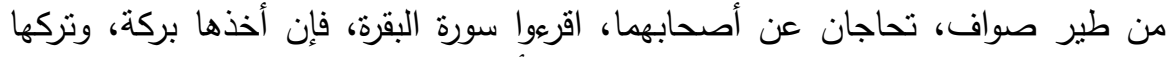
حسرة، ولا تستطيعها البطلةه، قال معاوية: أبلغني أن البطلة: السحرة. 
أنت؟ فيقول: أنا القرآن الذي أسهرت ليلك وأظمأت نهارك(')، وفي حديث البراء،

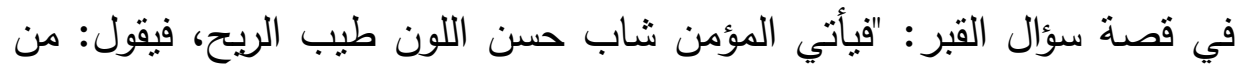

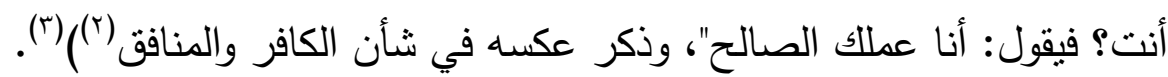

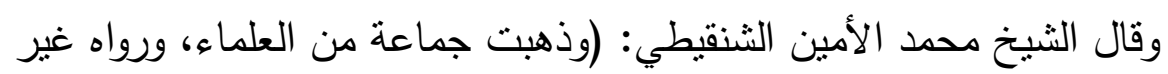

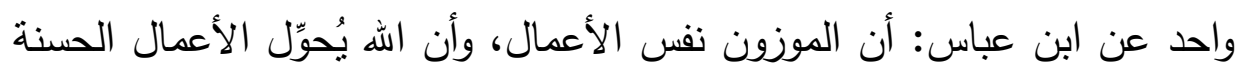

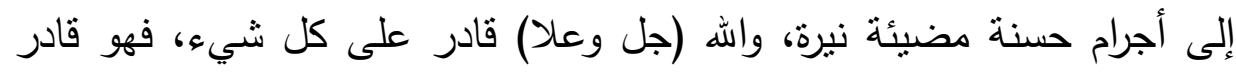

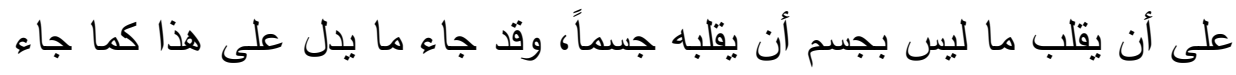

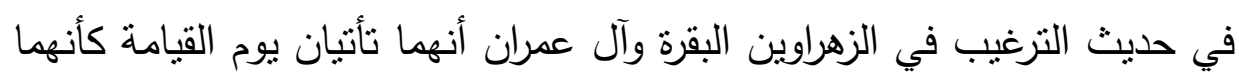

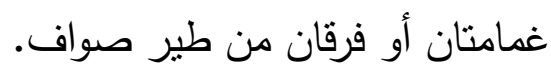

وكما جاء في الحديث أن عمل الإنسان ينجسم له في صورة إنسان طيب

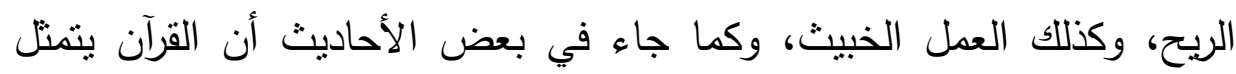

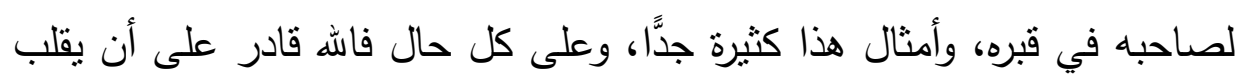

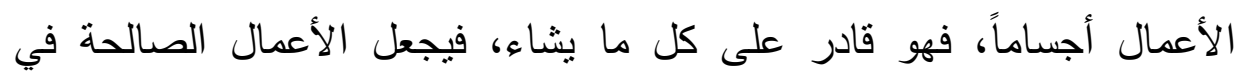

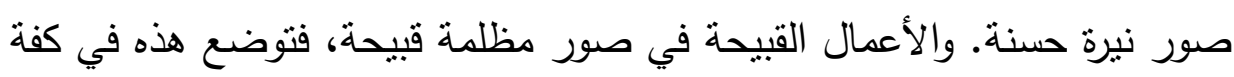

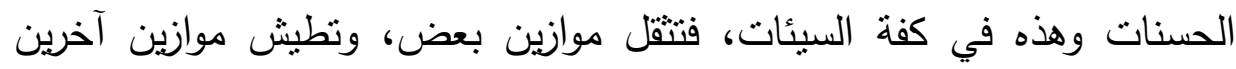
والعياذ بالة)(؛).

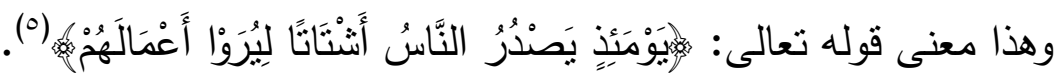

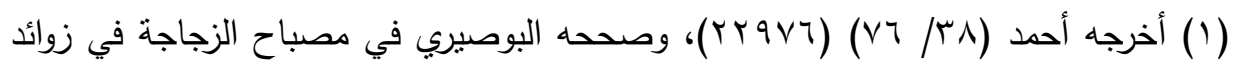

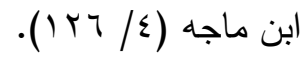

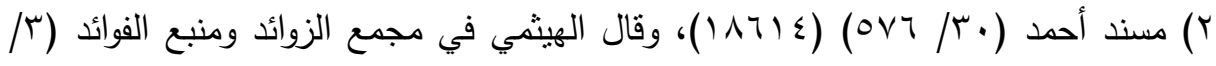

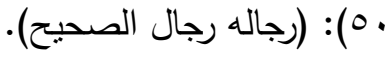

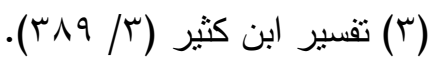

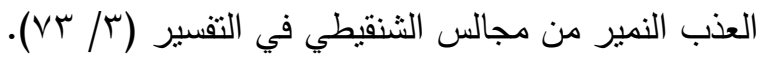




\section{د. ف فه صالح الخنه}

قال الطبري: (يومئذ يصدر الناس أشتاتا متفرقين، عن اليمين وعن الثمال، ليروا أعمالهم، فيرى المحسن في الدنيا، المطيع لله عمله وما أعد الله له يومئذ من الهن الكرامة، على طاعته إياه كانت في الدنيا، ويرى المسيء العاصي لله عمله وجزاء عمله وما أعد الله له من الهوان والخزي في جهنم على معصيته إياه كانت في

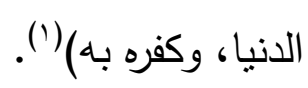
وقال ابن الجوزي: (قال ابن عباس: أي ليروا جزاء أعمالهم. فالمعنى: أنهم يرجعون عن الموقف فرقا لينزلوا منازلهم من الجنة والنار • وقيل: في الكلام تقديم وتأخير ، تقديره: تحدث أخبارها بأن ربك أوحى لها ليروا أعمالهم يومئذ يصدر الناس أثناتا. فعلى هذا: يرون ما عملوا من خير أو شر في موقف العرض) (؟). وفي معنى التسجيل البصري السابق التسجيل الصوتي الممنل في إنطاق

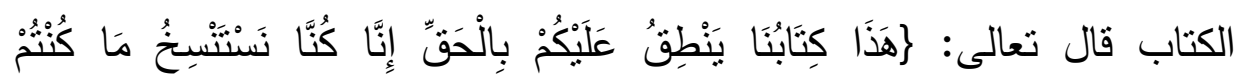

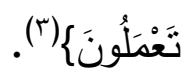

قال القرطبي: (هذا كتابنا" قيل من قول الله لهم. وقيل من قول الملائكة." ينطق عليكم بالحق" أي يشهد. وهو استعارة، يقال: نطق الكتاب بكذا أي بين. وقيل: إنهم يقرعونه فيذكرهم الكتاب ما عملوا، فكأنه ينطق عليهم) (ع). وما ذكره القرطبي لا يمنع أن ينطق الكتاب نفسه ليكون أبلغ في التحدي

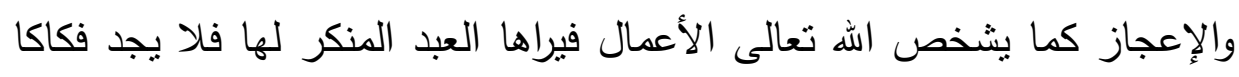
من الإذعان والاعتراف.

نسأل الله تعالى أن ييمن كتابنا ويبيض وجوهنا ويجعل نظرنا إلى أعمالنا نظر غبطة وسرور • - ن

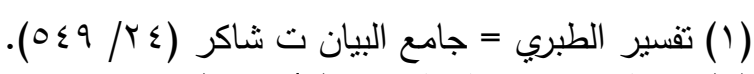

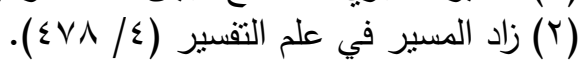

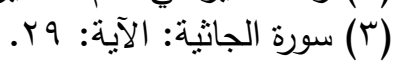

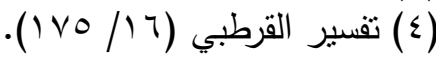




\section{المبحث التاسع}

\section{صور من الحساب الخاص}

أعرض في هذا المبحث لصور من الحساب الخاص، وهي بعض المواقف التي وردت في السنة النبوية، وظهرت فيها رحمة الله وفضله وكرمه لبعض عباده

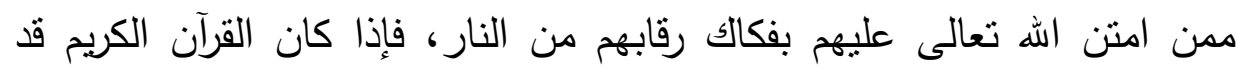

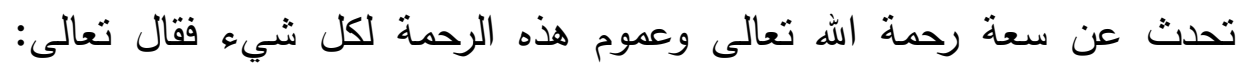

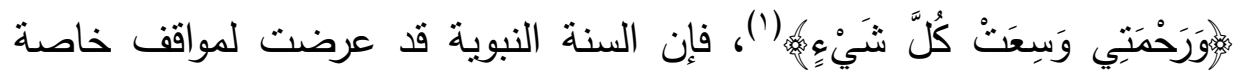
تظهر فيها آثار رحمة المولى تبارك وتعالى وسعة عفوه وعموم ستره لعباده

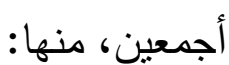

1- ما روي عن ابن عمر رضي اله عنه قال: سمعت رسول اله اله يقول:

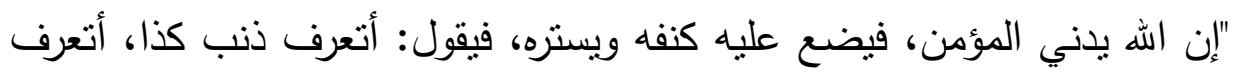
ذنب كذا؟ فيقول: نعم أب رب، حتى إذا قرره بذنوبه، ورأى في نفسه أنه هلأك،

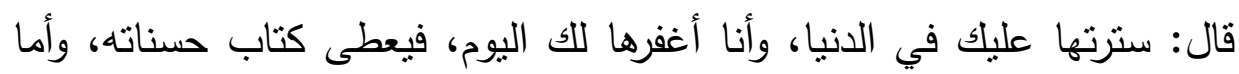

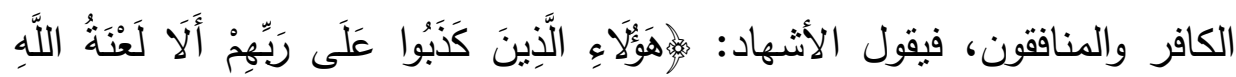

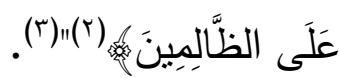
ففي هذا الحديث إثارة إلى فضل اله المديد يوم القيامة، حين يُسبل رحمته على بعض عباده ممن ارتكبوا بعض الذنوب، فيذكّر العبد بذنوبه ويقرره إياها فإذاذ أقر بها عفا عنه وشمله بستره.

$$
\text { (Y) سورة الأعراف، الآية: } 107 \text { (1) سود، الآية: 11. }
$$

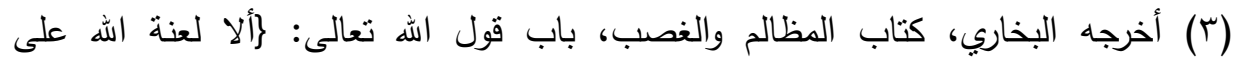

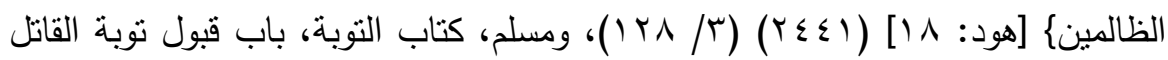

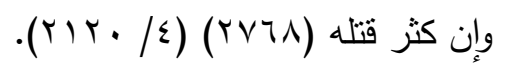




\section{د. د فه صالح الخنه}

قال المهلب: (فى هذا الحديث عظيم تقضل الله على عباده المؤمنين وستره لذنوبهم يوم القيامة، وأنه يغفر ذنوب من شاء منهم، بخلاف قول من أنفذ الوعيد على أهل الإيمان؛ لأنه لم يستثنِ فى هذا الحديث عليه السلام ممن يضع عليه

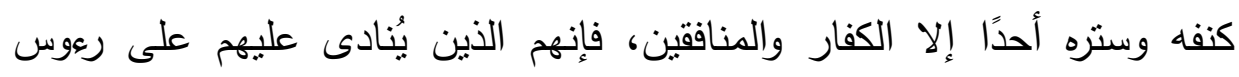

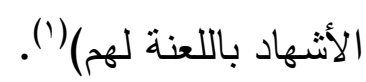

r- ما روي عن عبداله بن مسعود رضي الله أن رسول اله لهَ

من يدخل الجنة رجل، فهو يمشي مرة، ويكبو مرة، وتسفعه النار مرة، فإذا ما جاوزها التفت إليها، فقال: تبارك الذي نجاني منك، لقد أعطاني اله شيئا ما أعطاه أحدا من الأولين والآخرين، فترفع له شجرة، فيقول: يا رب، أدنني من هذه الثجرة

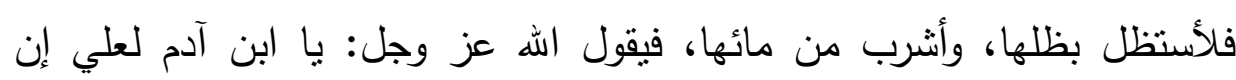
أعطيتكها سألتتي غيرها؟ فيقول: لا، يا رب ويعاهده أن لا يسأله غيرها، قال: وربه عز وجل يعذره؛ لأنه يرى ما لا صبر له عليه، فيدنيه منها، فيستظل بظلها،

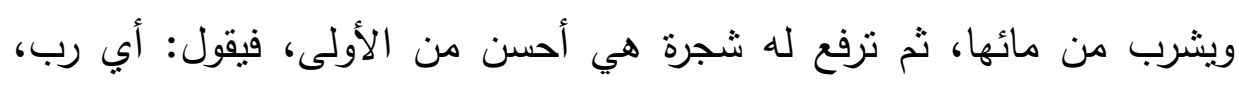
أدنني من الثجرة لأشرب من مائها وأستظل بظلها، لا أسألك غيرها، فيقول: يا ابن آدم، ألم تعاهدني أن لا تسألني غيرها؟ فيقول: لعلي إن أدنيتك منها تشألني

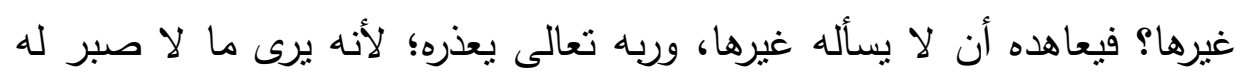

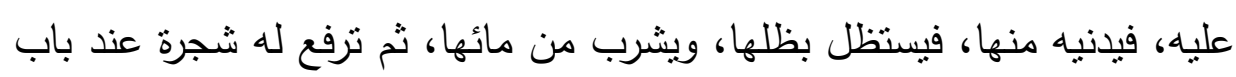
الجنة، وهي أحسن من الأوليين، فيقول: أي رب أدنني من هذه لأسنظل بظلها، وأشرب من مائها، لا أسألك غيرها، فيقول: يا ابن آدم، ألم تعاهدني أن لا تسألني

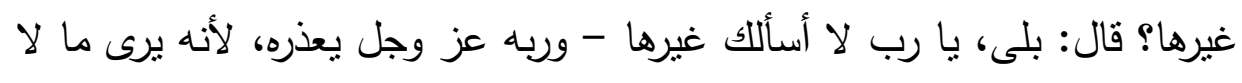

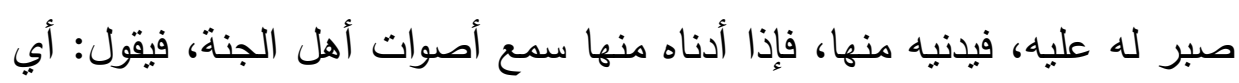
رب أدخلنيها، فيقول: يا ابن آدم، ما يصريني منك، أيرضيك أن أعطيك الدنيا 
ومتلها معها؟ قال: يا رب، أنستهزئ مني وأنت رب العالمين؟ فضحك ابن

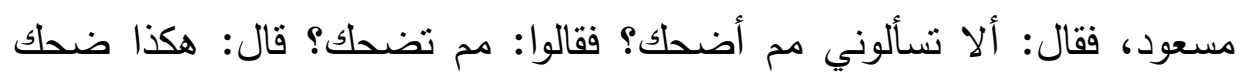

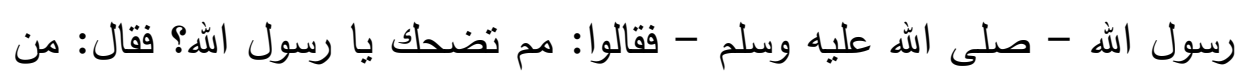

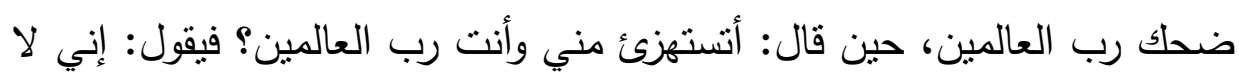

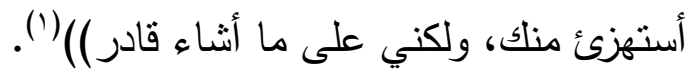

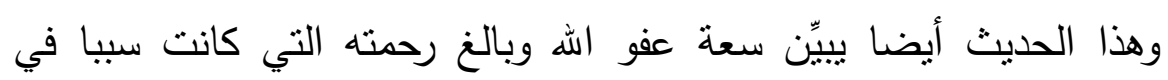
خروج هذا العبد من النار ودخوله الجنة وبسط النعيم له فيها.

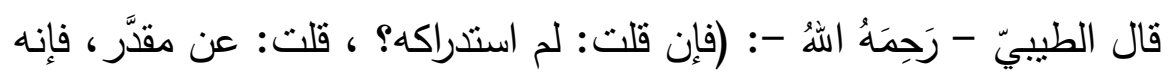

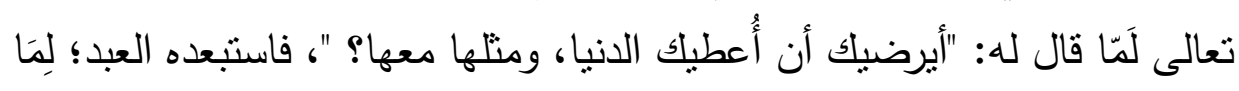

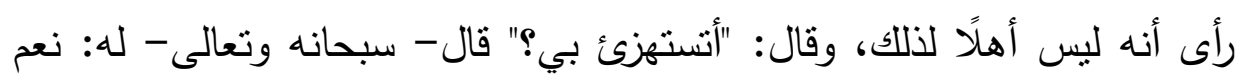

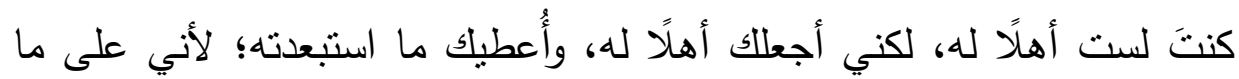

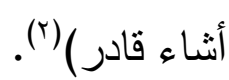

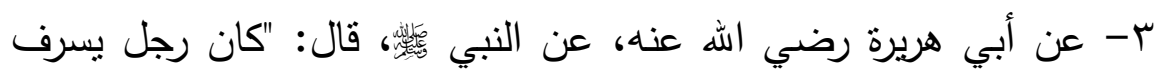

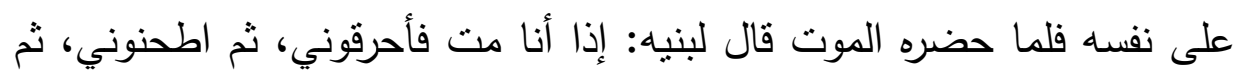

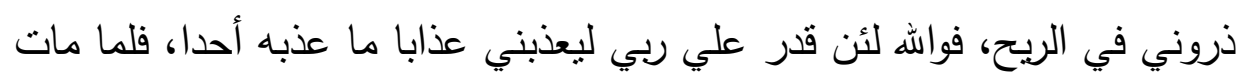

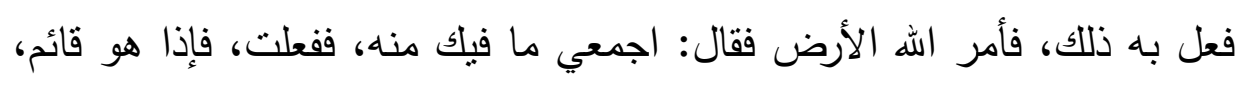

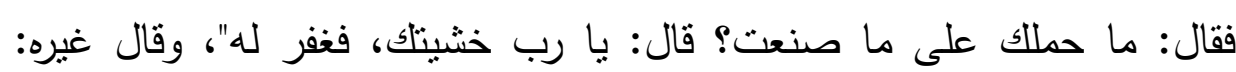

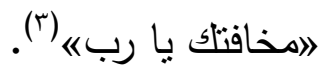

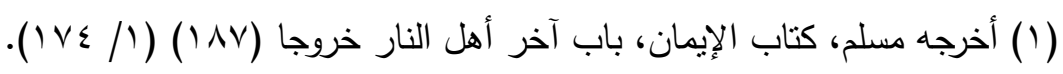

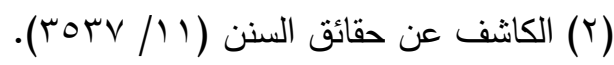

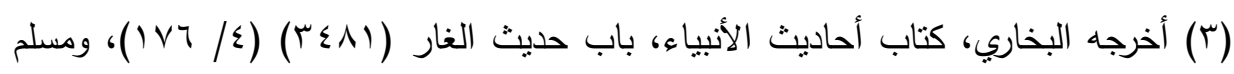

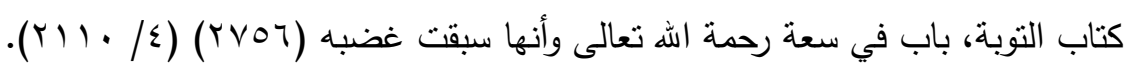




\section{د. ف فه صالح الخنه}

قال ابن حجر: (وهذا جمبعه - كما قال ابن عقيل - إخبار عما سيقع له يوم القيامة وليس كما قال بعضهم: إنه خاطب روحه؛ فإن ذلك لا يناسب قوله: "فجمعه الله"؛ لأن التحريق والتقريق إنما وقع على الجسد وهو الذي يجمع ويعاد

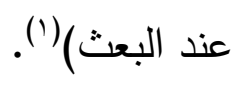

فيفيد الحديث أن الله تعالى رحم عبده الذي لم يعمل خيرا قط، وأبدله من العقوبة على ما فعل بالعفو والصفح، وذلك لمَّ كان الدافع له على ما أقدم عليه هو خوف الله بقصد حسن، فغفر الله له، وإن كان فعله خطأ وجهلاً بقدرة الله تعالى ومع ذللك عذره وغفر له(r).

فإذا كان هذا لمن ساء ظنه بربه وساء عمله ولم يرجُ رحمته، فكيف بمن كان يحسن الظن باله تعالى؛ ولهذا يقول النبي

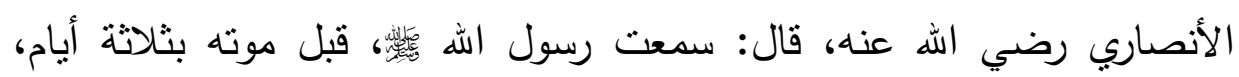
يقول: »لا يموتن أحدكم إلا وهو يحسن الظن باله عز وجله" آّ). قال ابن حجر العسقلاني: (المقصود من الرجاء: أن من وقع منه تقصير فليحسن ظنه باله ويرجو أن يمحو عنه ذنبه، وكذا من وقع منه طاعة يرجو قبولها، وأما من انهمك على المعصية راجيا عدم المؤاخذة بغير ندم ولا إقلاع فهذا

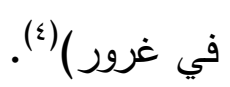

ع- عن عبد الله بن عمرو بن العاص، يقول: قال رسول الله

سيخلص رجلا من أمتي على رعوس الخلائق يوم القيامة فينشر عليه تشعة وتسعين سجلا كل سجل مثل مد البصر، ثم يقول: أتتكر من هذا شيئا؟ أظلمك

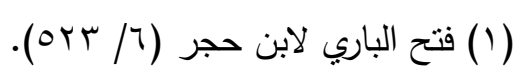

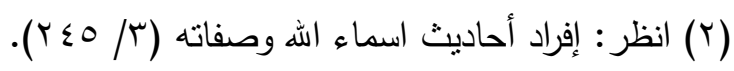

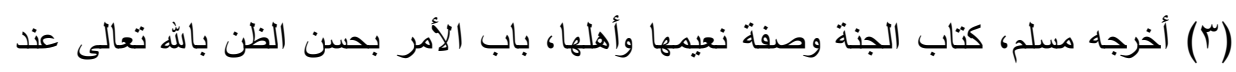

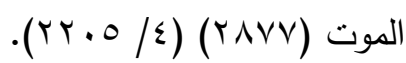

$$
\begin{aligned}
& \text { فتح الباري لابن حجر (11/ 1 • (r). }
\end{aligned}
$$


كتبتي الحافظون؟ فيقول: لا يا رب، فيقول: أفللك عذر؟ فيقول: لا يا رب، فيقول:

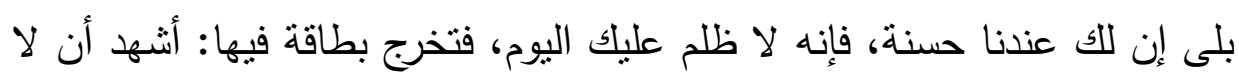

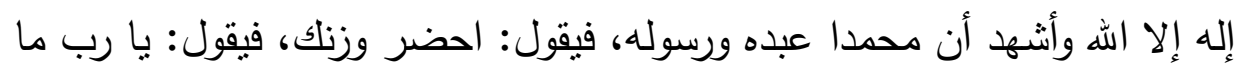

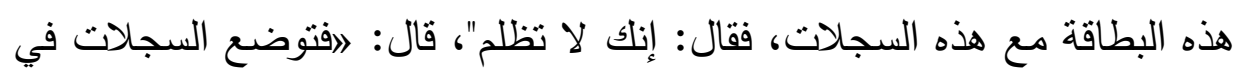

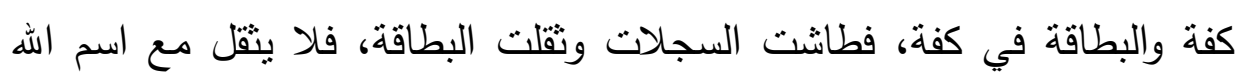
شيء (')

قال القاري: ("فلا ينقل مع اسم اله شيء") والمعنى: لا يقاومه شيء من

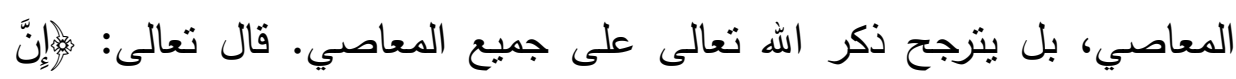

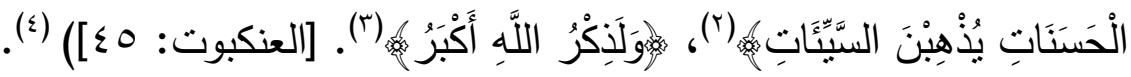

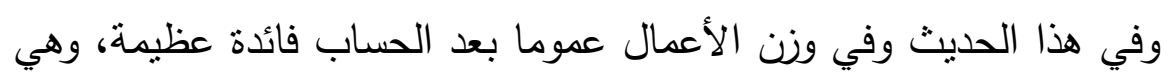
أن يعلم العباد "أنهم لو دخلوا الجنة قبل الموازنة ربما ظن الإل المطيع أنه نال

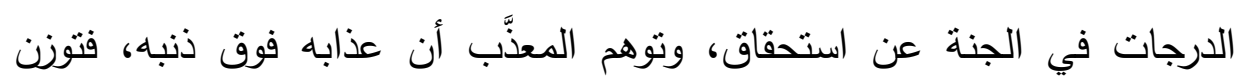

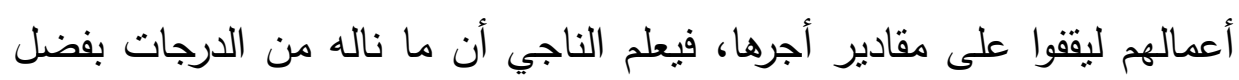

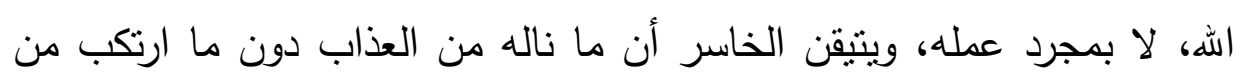

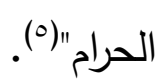

قال القسطلاني: (فكذلك وزنه تعالى لأعمال خلقه بالميزان حجة عليهم ولهم إما بالتقصير في طاعته والتضييع، وإما بالتكميل والتتميم، وإظهار لكرمه وعفوه

(1) أخرجه التزمذي، أبواب الإيمان، باب ما جاء فيمن يموت وهو يشها أن لا إله إلا الله

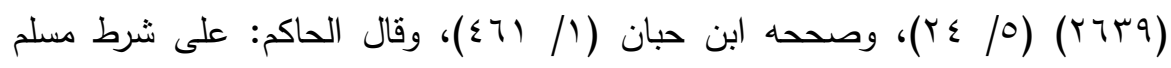

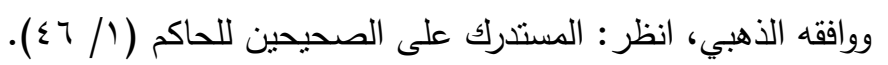

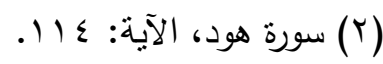

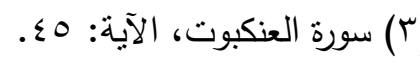

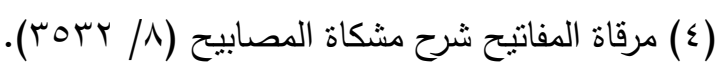

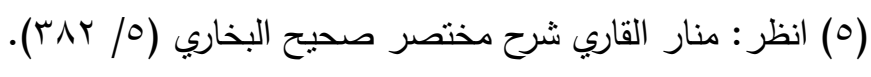

$$
\begin{aligned}
& -0 \text { प } 1-
\end{aligned}
$$




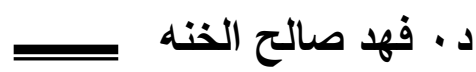

ومغفرته وحلمه مع قدرته بعد اطّلاع كل أحد منّا على مساويه ومسامحته له له وغفرانه وإدخاله إياه الجنة بعد معصيته) (').

وفي هذا الحديث كما في غيره بيان عظم منزلة الشهادنين وأنهما لا يعدلهما شيء في الفضل، وهذا ما تضافرت عليه الآيات القرآنية والأحاديث النبوية، فقال

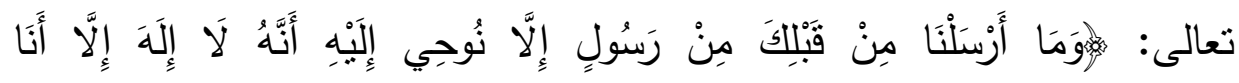

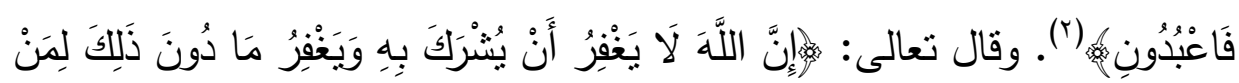

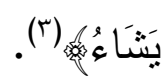

ودلت الأحاديث والآثار كذلك على عظم منزلة "لا إله إلا الله"، مثلما ورد في قوله الملك وله الحمد وهو على كل شيء قدير"((£). وعنه لها

$$
\text { وجه الله"(0). }
$$

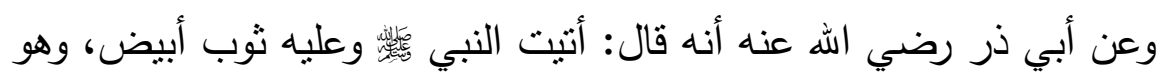
نائم، ثم أثتيه وقد استيقظ، فقال: "ما من عبد قال: لا إله إلا الله، ثم مات على ذلك إلا دخل الجنة"، قلت: وإن زنى وإن سرق؟ قال: اوإن زنى وإن سرقه، قلت: وإن زنى وإن سرق؟ قال: 》وإن زنى وإن سرقه، قلت: وإن زنى وإن سرق؟ قال:

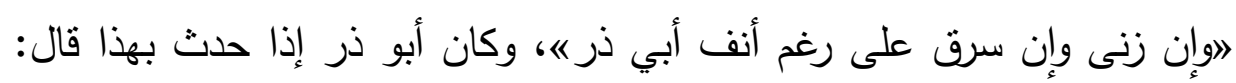

$$
\begin{aligned}
& \text { (1) إرشاد الساري لشرح صحيح البخاري (· (1/ 1) ). }
\end{aligned}
$$

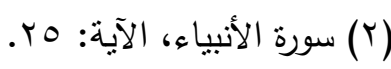

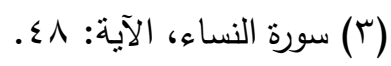

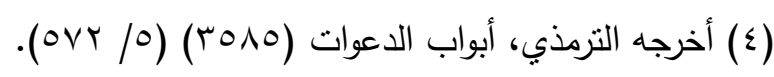

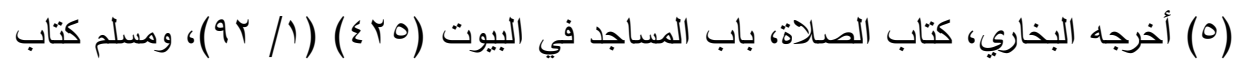

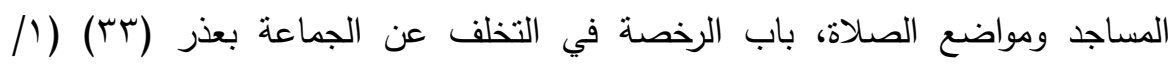


وإن رغم أنف أبي ذر قال أبو عبد الله: هذا عند الموت، أو قبله إذا تاب وندم، لأ إنه

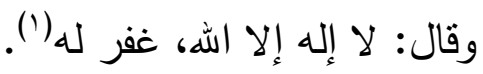

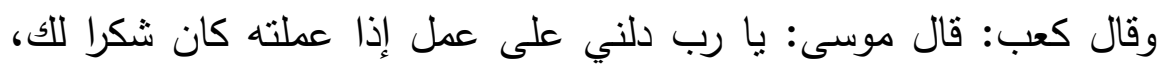

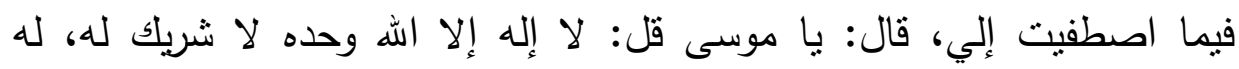

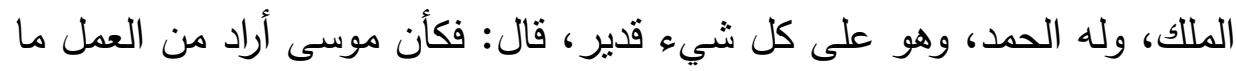

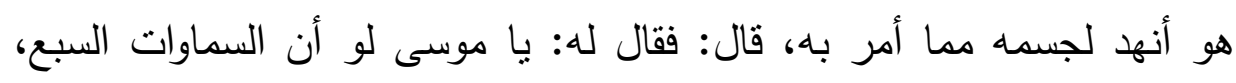

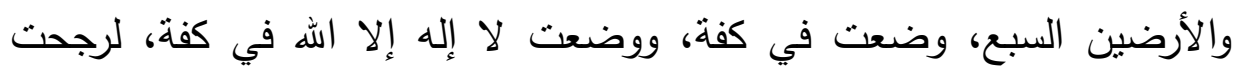

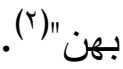

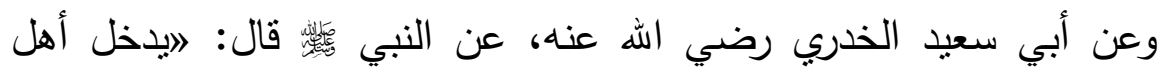

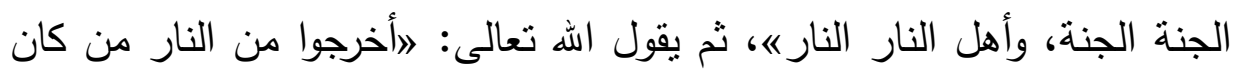

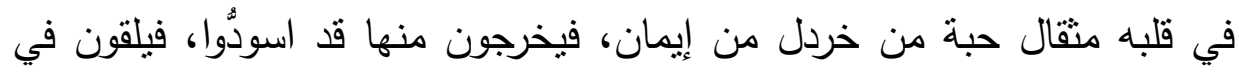

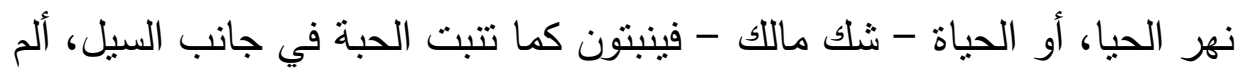

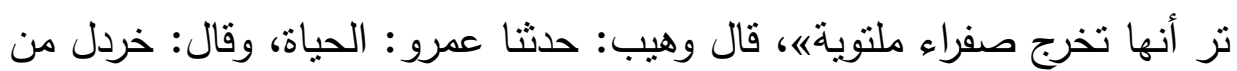

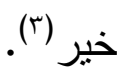

وفي معناه حديث أنس، عن النبي أس قال: إيخرج من النار من قال لا إله

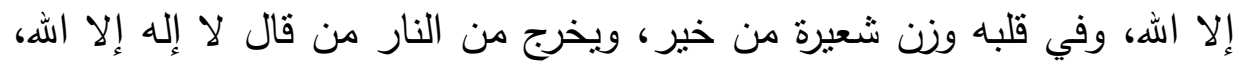

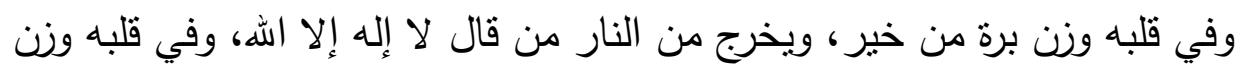

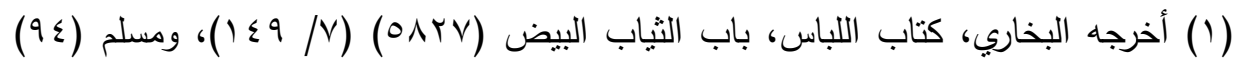
(90/1)

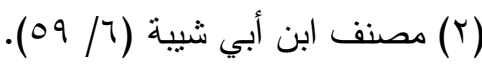

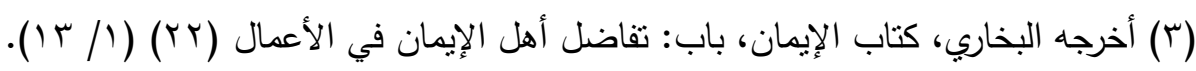




\section{د. ف فه صالح الخنه}

ذرة من خير شال أبو عبد الله: قال أبان، حدثنا قتادة، حدثنا أنس، عن النبي

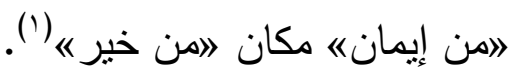

قال السفيري: (والمعنى: أخرجوا من النار من في قلبه مثقال حبة من خردل إيمان، وإنما أتى 》ابحبه الخردله دون غيرها من البذورات؛ لأنها في غاية هنية الصغر ، فلهذا يُشبَّهه بها للبالغ في القلة أي: أخرجوا من النار من بلغ إيمانه إلى هلى

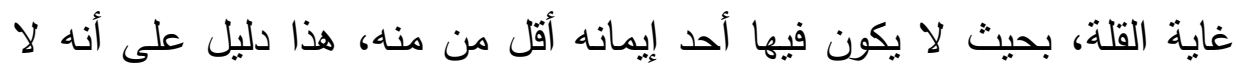
يبقى في النار من أهل الإيمان من العصاة أحد من قل إيمانه أو كثر، تفضلاً منه سبحانه وكرماً. وكم من عاص تفضل الله عليه وعفا عنه وسامحه، من غير الإبطان سبق عذاب في البرزخ ولا في الآخرة، بل عامله بحسن ظن فأدخله الجنة)(r). وقال الأبي: (هؤلاء الذين أخرجوا من النار برحمة اله سبحانه وتعالى من

ليس عندهم إلَّا مجرد الإيمان وإنما يخرجون بشفاعة أرحم الراحمين) (ّ). فهذه بعض صور الحساب الخاص الذي يظهر فيها عفو الله تعالى وكرمه، وامتتانه على بعض عباده مدن استوجب العقوبة أو دخل النار، فيشمله عفوه فيخرج من النار أو يدخل الجنة وإن استحق العقوبة.

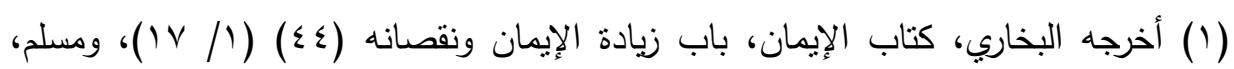

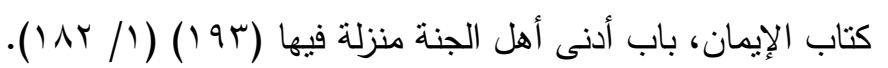

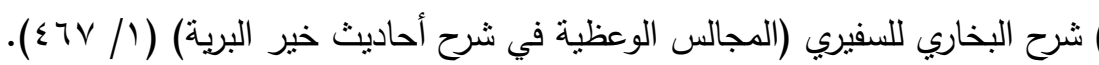

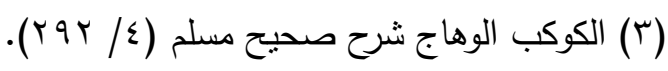




\section{نتائج الدراسة}

بـ الصورة الجامعة للحساب في القرآن الكريم هي صورة الحساب التي تتشتمل على المساءلة والوزن والمجازاة، وهذا الحساب على نوعين؛ النوع الأول أعده

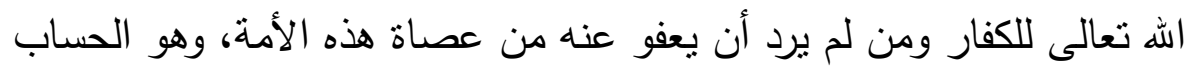

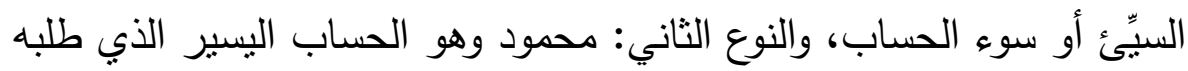

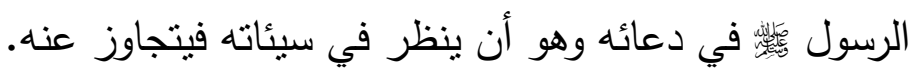

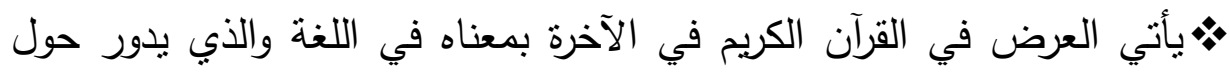

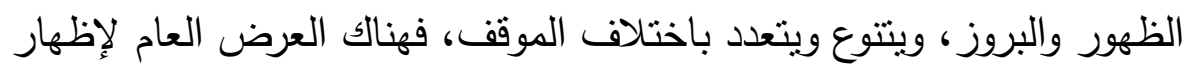

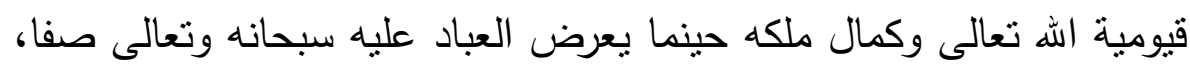

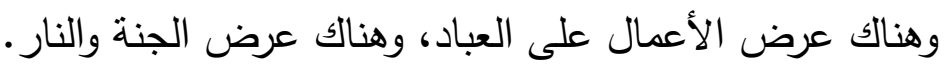

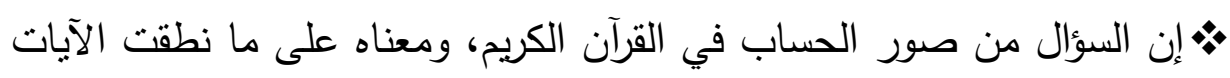

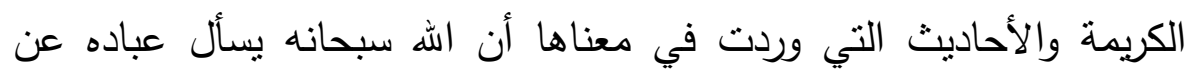

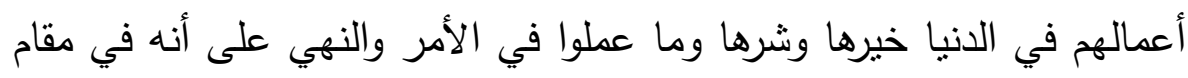

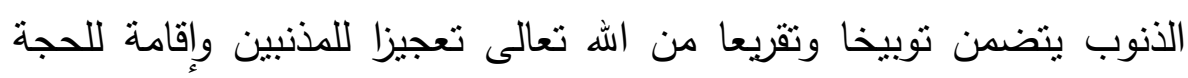

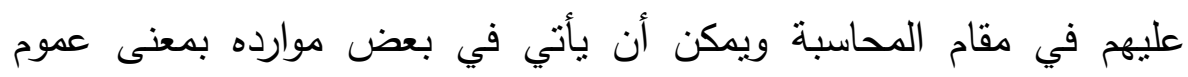
المحاسبة، فيكون كنية عن عملية المحاسبة في الآخرة بأسرها.

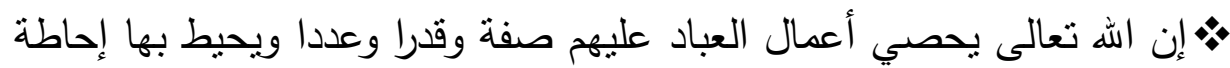
تامة، فلا يغيب عنه مثقال ذرة مما عملوه، ثم يجازيهم عليها. ولكتابة الأعمال نفس معنى الإحصاء، فالكتابة هنا كتابة إحصاء ورصد دقيق لكل ما يصدر

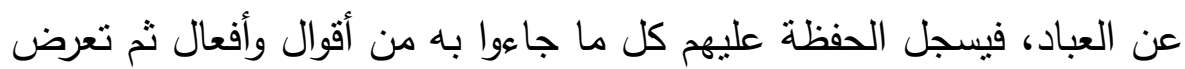
عليهم يوم القيامة ليجازوا عليها بما يتتاسب معها.

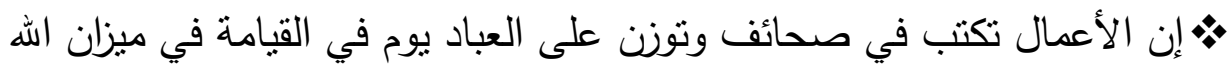
تعالى أعلم بحقيقته وكيفيته، فتوضع حسنات العبد في كفة وتوضع سيئاته في 


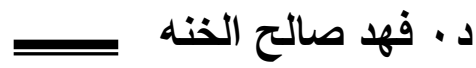

كفة، فإذا رجحت كفة الحسنات فالعبد إلى الجنة، وإذا خفت هذه الكفة فرجحت السيئات فالعبد إلى النار إن كان كافرا فيخلد فيها، وهو في مشيئة الله إن كان مؤمنا عاصيا، أعاذنا الله من عذاب النار ومشهدها. • اقتضى عدل الله تعالى أن يجعل على بني آدم في الآخرة شهودا يثبتون عليهم التهمة إذا أنكروا أو جحدوا ما ينبئهم الله تعالى به أو نسوه، فإن بعض الناس

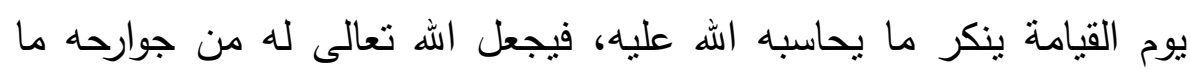
يشهر عليه، فيكون هو الثاهد على نفسه وليس أبلغ من ذلك في الثهادة. مأثنار القرآن الكريم إلى أن الناس في الآخرة منهم من يتتاول كتابه بيمينه فهذا بستبشر ويقرأ كتابه، فهذا هو المؤمن، وهذا إذا نظر في الكتاب - فرح به واستبشر بما فيه؛ فسهل عليه القراءة، فيقرأ كتابه مستبشرا ويدعو غيره لقراءة كتابه، ومنهم من يتتاول كتابه بشماله من وراء ظهره، وهذا هو الكافر الذي إذا نظر في الكتاب، حزن واغتم به؛ فعسر عليه قراءة كتابه، فيتمنى لو أنه لم يتتاول كتابه أو أن حياته انتهت إلى مرحلة لم تصل به إلى العذاب. ثإذا كان القرآن الكريم قد تحدث عن سعة رحمة الله تعالى وعموم هذه الرحمة

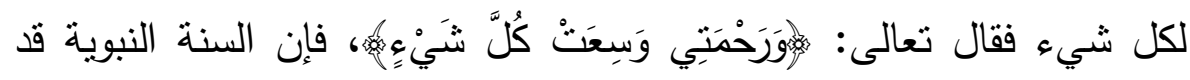
عرضت لمواقف خاصة تظهر فيها آثار رحمة المولى تبارك وتعالى وسعة عفوه وعموم ستره لعباده. • إذا كان العلم الحديث قد وصل إلى اختراعات استطاع بها أن يحفظ الصورة وأن يسجل الأصوات، فإن الله سبحانه وتعالى بقرته أقدر على تسجيل كل أعمال البشر وعرضها عليهم في الآخرة، وقد يفهم ذلك من بعض آيات صور الحساب في القرآن الكريم. 


\section{= صور الحساب \\ المصادر والمراجع}

( ) تفسير الماوردي، (النكت والعيون)، تأليف: علي بن محمد بن محمد بن

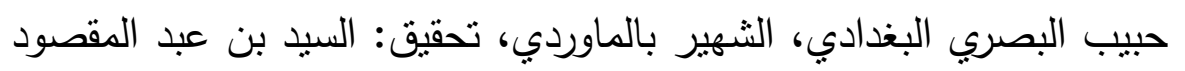

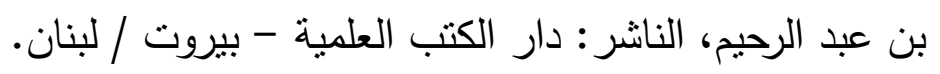

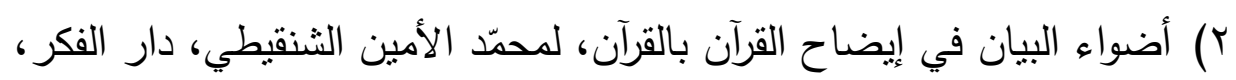

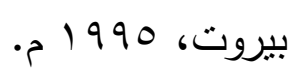

r) إكمال المعلم بفوائد مسلم، للقاضي عياض، تحقيق: الدكتور يحيى إسماعيل،

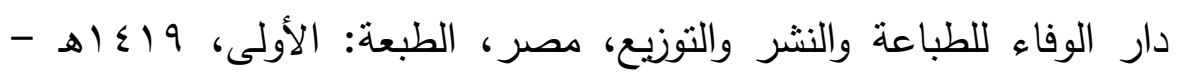

$$
\text { م } 1991
$$

ع) التحرير والتتوير، للطاهر بن عاثور، الدار التونسية للنشر ، تونس، ع 9 ام.

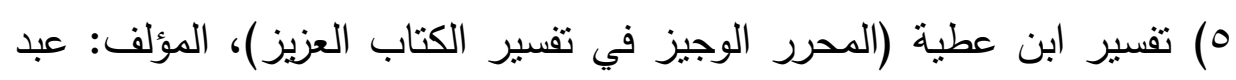

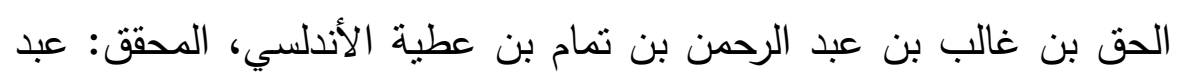

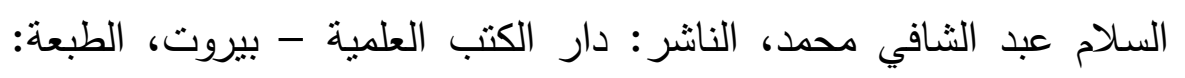

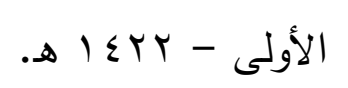

7) تفسير ابن فورك، لأبي بكر بن فورك، دراسة وتحقيق: عال عبد القادر

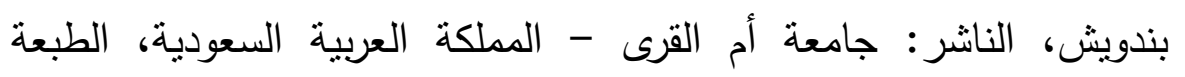

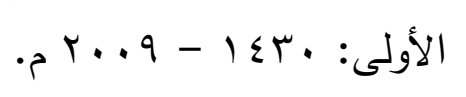

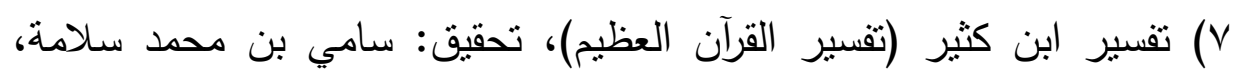

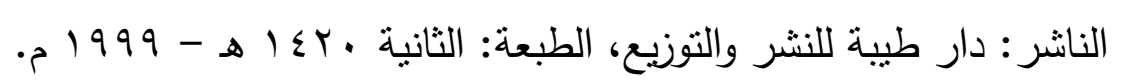

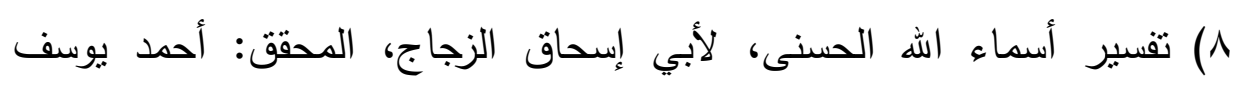
الدقاق، الناشر : دار الثقافة العربية.

9) تفسير البغوي (معالم النتزيل في تفسير القرآن) لأبي محمد الحسين بن مسعود

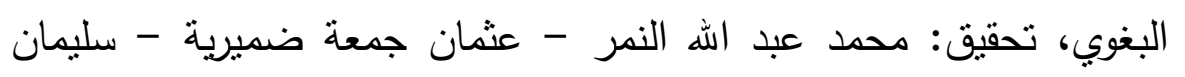




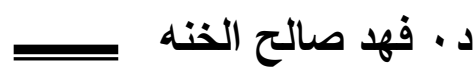

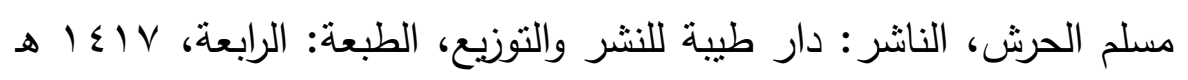

$$
\text { .5) } 99 \mathrm{~V}-
$$

• () تفسير البيضاوي (أنوار التنزيل وأسرار التأويل)، عبد الله بن عمر البيضاوي، المحقق: محمد عبد الرحمن المرعشلي، الناشر : دار إحياء التراث العربي -

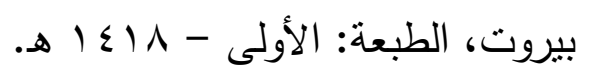

(1) تفسير التستري، سهل بن عبد الله بن يونس بن رفيع النُشتري، جمعها: أبو بكر محمد البلدي، المحقق: محمد باسل عيون السود، الناشر: منشورات محمد علي بيضون / دارالكتب العلمية - بيروت، الطبعة: الأولى - برئ

$$
\text { هـ } 1 \leqslant T
$$

Y ( ) تفسير الزمخشري، دار الكتاب العربي، بيروت، الطبعة الثالثة، V • ع أه. با ا) تفسير السمرقندي، أبو الليث نصر بن محمد بن أحمد بن إبراهيم

$$
\text { السمرقندي. }
$$

ء ( ) تفسير السمعاني، أبو المظفر السمعاني، تحقيق: ياسر بن إبراهيم وغنيم بن عباس بن غنيم، دار الوطن، الرياض - السعودية، الطبعة: الأولى،

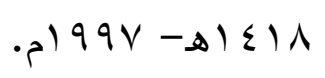

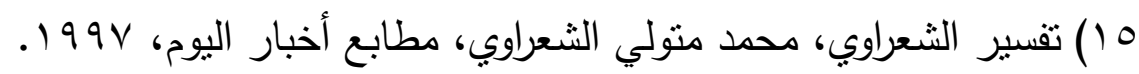
7 ( ) تفسير الطبري (جامع البيان في تأويل القرآن)، لمحمد بن جرير بن بزيد بن بن كثير بن غالب الآملي، أبو جعفر الطبري، تحقيق: الدكتور عبد الله بن عبد المحسن التركي، الناشر: دار هجر للطباعة والنشر، الطبعة: الأولى،

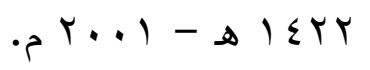

V V V V V القير القرطبي، (الجامع لأحكام القرآن)، تحقيق: الدكتور عبد الله بن عبد

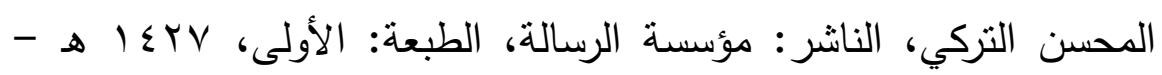

$$
\cdot r \cdot T
$$




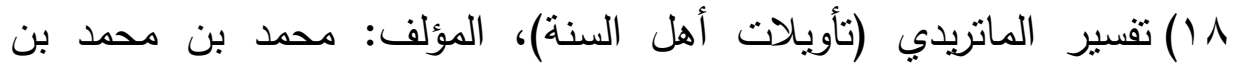

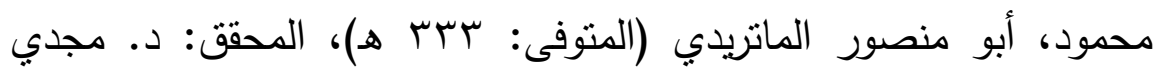

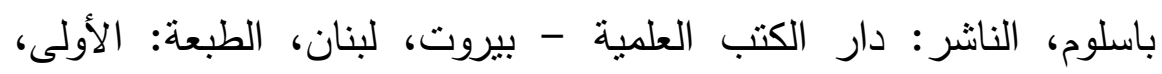
דr

9 (1) تفسير النسفي، (مدارك التنزيل وحقائق التأويل)، عبد اله بن أحمد بن

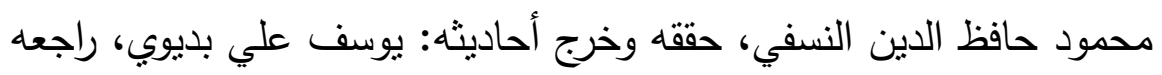

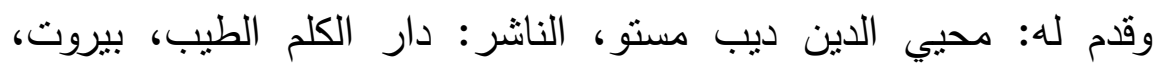

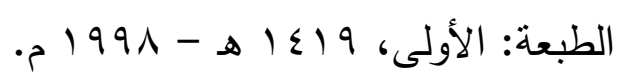

• r r تهذيب اللغة للأزهري، تحقيق: محمد عوض مرعب، دار إحياء التراث

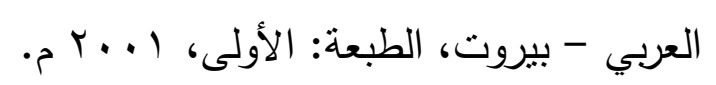

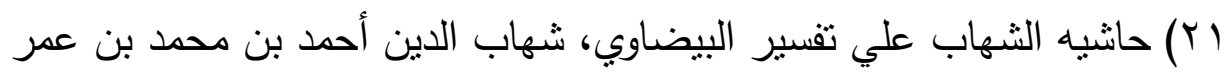

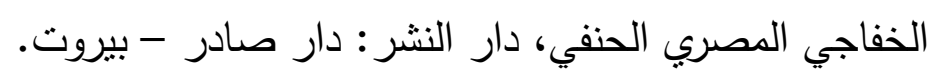

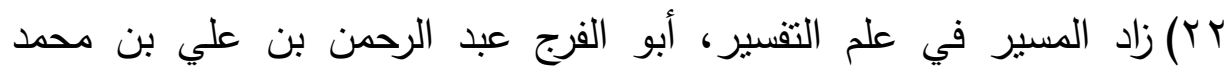

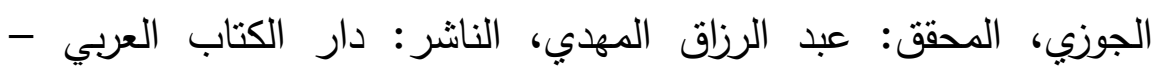

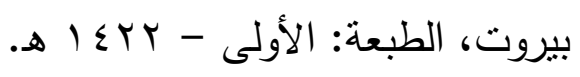

r آ) الزهد لأبي داود السجستاني، دار المشكاة للنشر والتوزيع، حلوان، الطبعة:

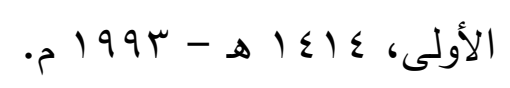

צY) زهرة التفاسير ، محمد أبو زهرة، دار الفكر العربي.

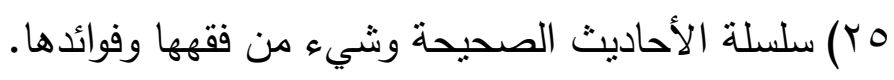

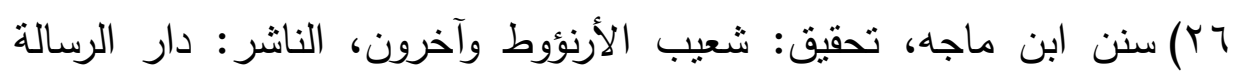

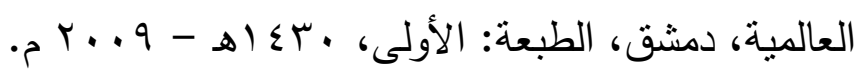




\section{د. ف فر صالح الخنه}

سنن الترمذي، لمحمد بن عيسى الترمذي، تحقيق: أحمد محمد شاكر، ومحمد فؤاد عبد الباقي، وإبراهيم عطوة عوض، الناشر: مكنبة ومطبعة مصطفى البابي الحلبي - مصر ، الطبعة: الثانية، و9 1 19 هـ - 19 م. ^^) شرح أصول اعتقاد أهل السنة والجماعة، لأبي القاسم اللالكائي، تحقيق: أحمد بن سعد بن حمدان الغامدي، الناشر : دار طيبة - السعودية، الطبعة:

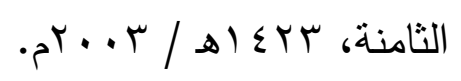

وץ) شرح صحيح البخارى، لعلي بن خلف بن بطال، تحقيق: ياسر بن إبراهيم،

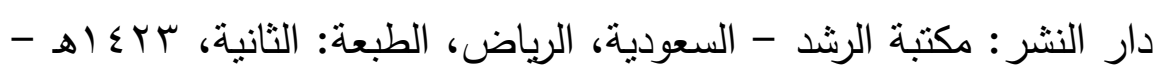

$$
\text { r. }
$$

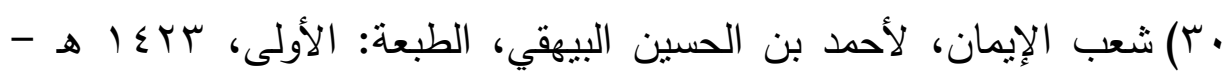
r. r.

اب( الصحاح، للجوهري، تحقيق: أحمد عبد الغفور عطار، الناشر: دار العلم

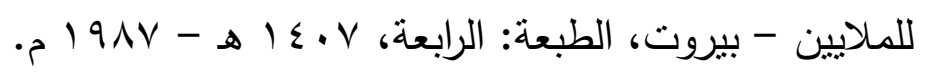

rrr) صحيح البخاري، للإمام محمد بن إسماعيل أبو عبداله البخاري، تحقيق: محمد زهير بن ناصر الناصر، الناشر: دار طوق النجاة. الطبعة: الأولى،

هـ $1 \leqslant r$

سب) صحيح مسلم، للإمام مسلم بن الحجاج النيسابوري، تحقيق: محمد فؤاد عبد

$$
\text { الباقي. }
$$

ع ب) طرح التثريب في شرح التقريب، زين الدين العراقي، الطبعة المصرية

القديمة - وصورتها دور عدة منها (دار إحياء التراث العربي، ومؤسسة

$$
\text { التاريخ العربي، ودار الفكر العربي). }
$$

هب) فتح البيان في مقاصد القرآن، للقنوجي، تحقيق: عَبد الله بن إبراهيم الأنصناري، المكتبة العصرية، بيروت، بو 199 م. 
بr) فتح القدير للشوكاني، الناشر : دار الكلم الطيب - دمثق، بيروت، الطبعة:

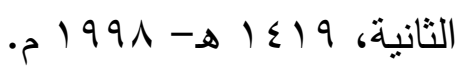

- الفتوحات الإلهية، سليمان الجمل

^ץ) الكوكب الوهاج شرح صحيح مسلم، محمد الأمين بن عبد الله الأُّمي العَلَوي الهَرَري الثنافعي، مراجعة: لجنة من العلماء برئاسة البرفسور هاشم محمد

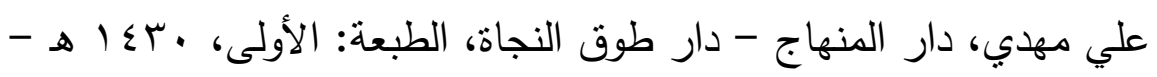

$$
\text { . } r \text {. } 9
$$

q) اللباب في علوم الكتاب، عمر بن عادل الحنبلي، المحقق: الثيخ عادل أحمد عبد الموجود والثيخ علي محمد معوض، الناشر : دار الكتب العلمية-

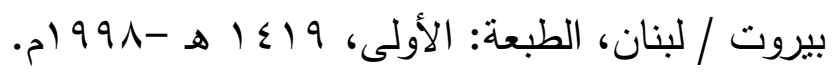

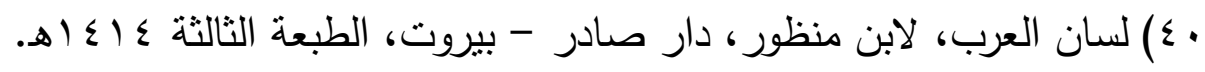
(ع) مختار الصحاح، لأبي عبد الله الرازي، تحقيق: يوسف الثيخ محمد، الناشر: المكتبة العصرية - الدار النموذجية، بيروت - صيدا، الطبعة: الخامسة،

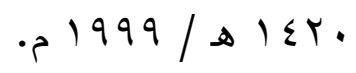

Y ₹ مرقاة المفاتيح شرح مشكاة المصابيح، علي بن سلطان القاري، دار الفكر،

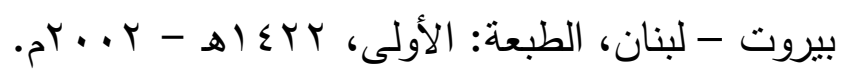

r؟) المستدرك على الصحيحين، للحاكم النيسابوري، تحقيق: مصطفى عبد القادر عطا، الناشر: دار الكتب العلمية - بيروت، الطبعة: الأولى،

$$
.199 \cdot-1 \leqslant 11
$$

§ ) مسند أحمد، للإمام أحمد بن حنبل، تحقيق: شعيب الأرنؤوط - عادل مرشد،

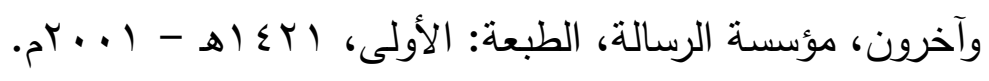

○؛) مصنف ابن أبي شيبة، تحقيق: كمال يوسف الحوت، الناشر : مكنبة الرشد-

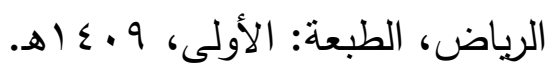




\section{د. ف فه صالح الخنه ل}

7૬) معاني القرآن، لأبي زكريا الفراء، المحقق: أحمد يوسف النجاتي / محمد علي النجار / عبد الفتاح إسماعيل الثلبي، الناشر: دار المصرية للتأليف والترجمة - مصر ، الطبعة: الأولى.

S V V معاني القرآن وإعرابه، لأبي إسحاق الزجاج، تحقيق: عبد الجليل عبده شلبي،

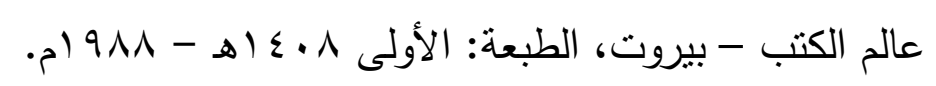

§ § ) المعجم الأوسط، للطبراني، تحقيق: طارق بن عوض الله بن محمد ، عبد المحن بن إبراهيم الحسيني، الناشر: دار الحرمين - القاهرة، الطبعة:

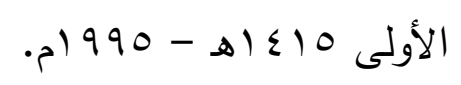

؟ \) معجم وتفسير لغوى لكلمات القرآن، المؤلف: حسن عز الدين بن حسين بن عبد الفتاح أحمد الجمل، الناشر: الهيئة المصرية العامة للكتاب، مصر،

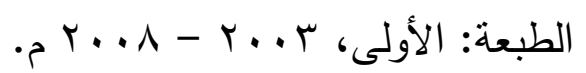

• م) مفاتيح الغيب، المؤلف: أبو عبد الله محمد بن عمر الملقب بفخر الدين

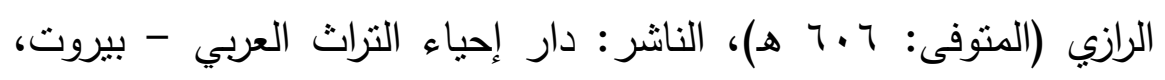

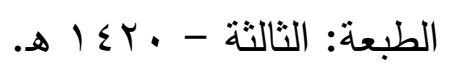

(ه) المفردات في غريب القرآن، للراغب الأصفهاني، المحقق: صفوان عدنان الداودي، الناشر: دار القلم، الدار الثامية - دمشق بيروت، الطبعة:

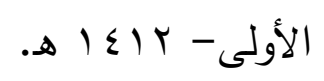

ror) المقاصد الحسنة في بيان كثير من الأحاديث المشتهرة على الألسنة، لشمس هم الدين السخاوي، تحقيق: محمد عثمان الخشت، الناشر : دار الكتاب العربي-

$$
\text { بيروت، الطبعة: الأولى، } 0 \text {. ع اهـ - } 910 \text { ام. م. }
$$

ro المقصد الأسنى في شرح معاني أسماء اله الحسنى، للغزالي، تحقيق: بسام

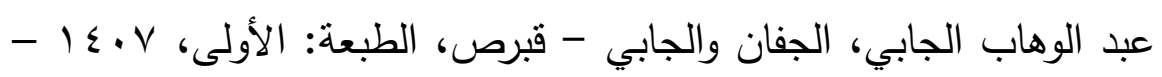




\section{= صور الحساب}

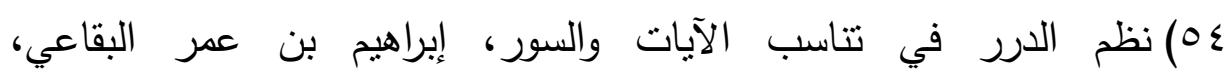

$$
\text { دار الكتاب الإسلامي، القاهرة. }
$$

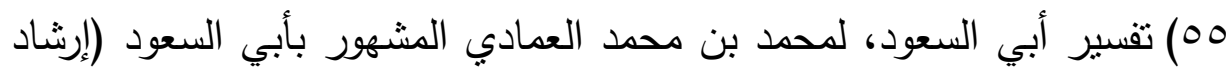

العقل السليم إلى مزايا الكتاب الكريم)، دار إحياء التزاث العربي - بيروت. 